OAK RIDGE

ORNL/TM-2009/110

NATTONAL LABORATORY

MANAGED BY UT-BATTELLE

FOR THE DEPARTMENT OF ENERGY

\title{
Profile of World Uranium Enrichment Programs—2009
}

\author{
April 2009
}

Prepared by

M. D. Laughter

Global Nuclear Security Technology Division
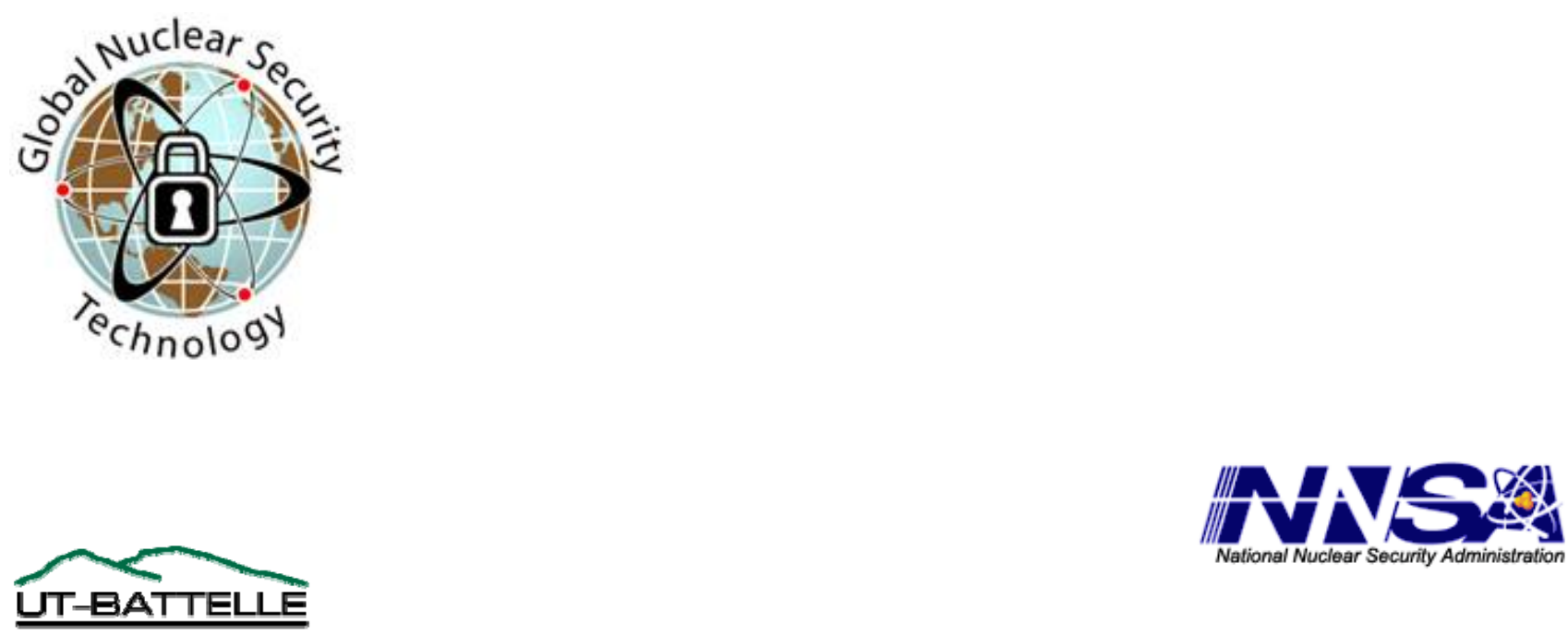


\section{DOCUMENT AVAILABILITY}

Reports produced after January 1, 1996, are generally available free via the U.S. Department of Energy (DOE) Information Bridge:

Web site: http://www.osti.gov/bridge

Reports produced before January 1, 1996, may be purchased by members of the public from the following source:

National Technical Information Service

5285 Port Royal Road

Springfield, VA 22161

Telephone: 703-605-6000 (1-800-553-6847)

TDD: $703-487-4639$

Fax: 703-605-6900

E-mail: info@ntis.fedworld.gov

Web site: http://www.ntis.gov/support/ordernowabout.htm

Reports are available to DOE employees, DOE contractors, Energy Technology Data Exchange (ETDE) representatives, and International Nuclear Information System (INIS) representatives from the following source:

Office of Scientific and Technical Information

P.O. Box 62

Oak Ridge, TN 37831

Telephone: 865-576-8401

Fax: 865-576-5728

E-mail: reports@adonis.osti.gov

Web site: http://www.osti.gov/contact.html

\section{DISCLAIMER}

This report was prepared as an account of work sponsored by an agency of the United States Government. Neither the United States Government nor any agency thereof, nor any of their employees, makes any warranty, express or implied, or assumes any legal liability or responsibility for the accuracy, completeness, or usefulness of any information, apparatus, product, or process disclosed, or represents that its use would not infringe privately-owned rights. Reference herein to any specific commercial product, process, or service by trade name, trademark, manufacturer, or otherwise, does not necessarily constitute or imply its endorsement, recommendation, or favoring by the United States Government or any agency thereof. The views and opinions of authors expressed herein do not necessarily state or reflect those of the Unites States Government or any agency thereof. 
Global Nuclear Security Technology Division

International Safeguards Group

\section{PROFILE OF WORLD URANIUM ENRICHMENT PROGRAMS-2009}

M. D. Laughter

Date Published: April 2009

This work supported by the

National Nuclear Security Administration

Office of Nonproliferation and International Security (NA-24)

Prepared by

OAK RIDGE NATIONAL LABORATORY

Oak Ridge, Tennessee 37831-6254

managed by

UT-BATTELLE, LLC

for the

U.S. DEPARTMENT OF ENERGY

under contract DE-AC05-00OR22725 



\section{CONTENTS}

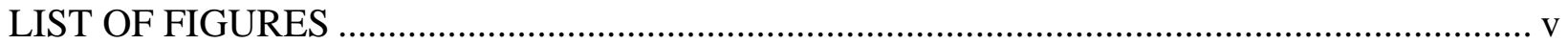

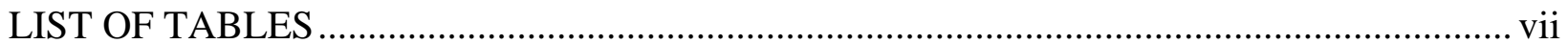

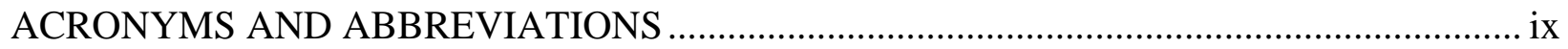

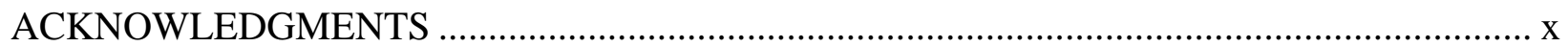

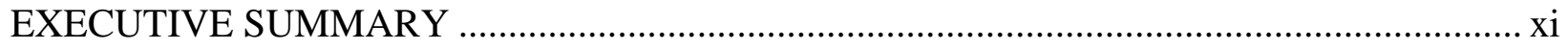

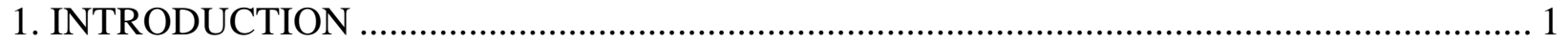

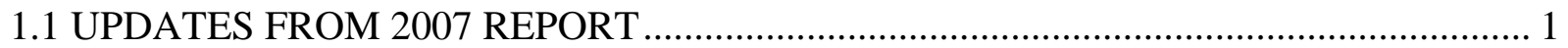

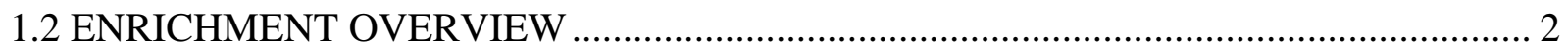

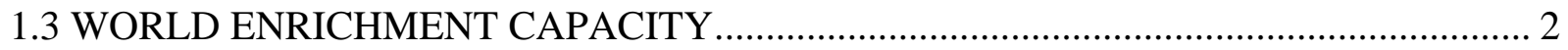

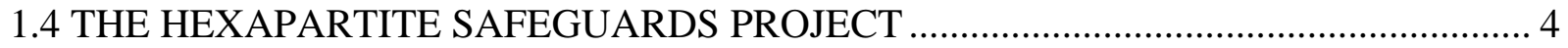

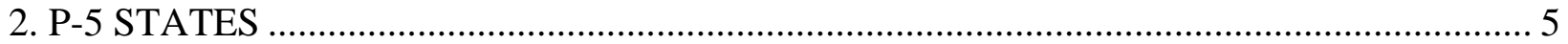

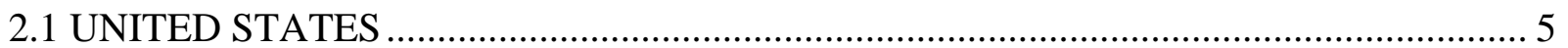

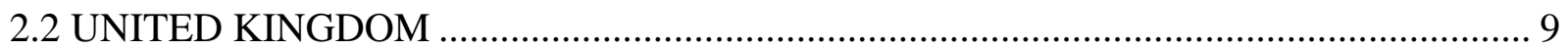

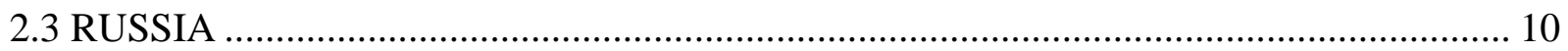

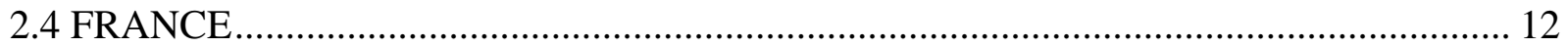

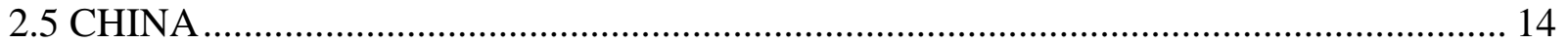

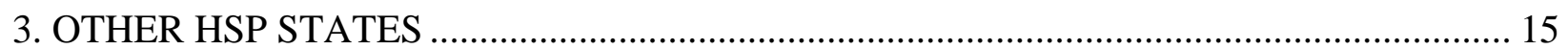

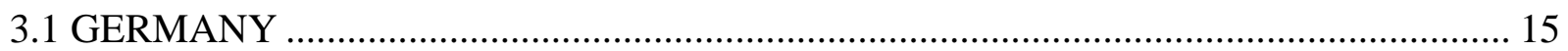

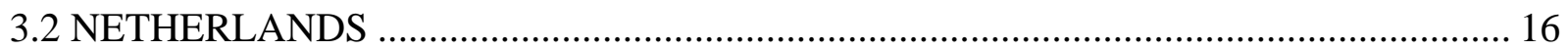

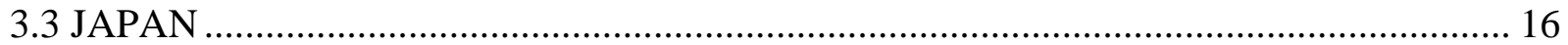

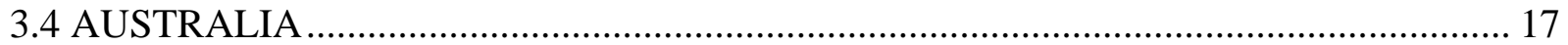

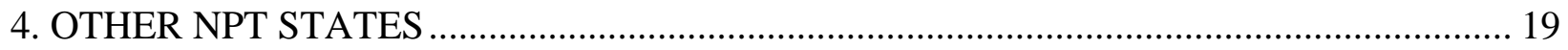

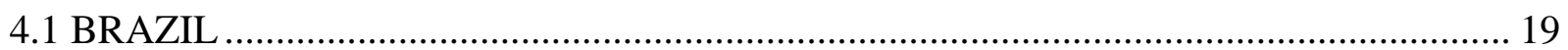

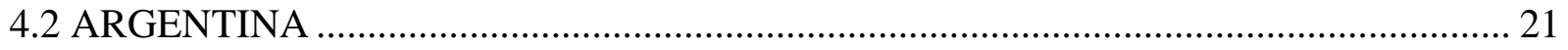

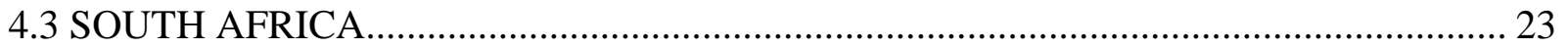

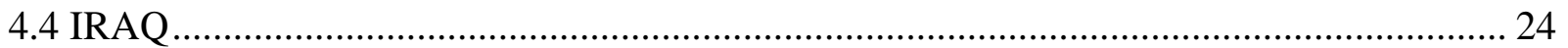

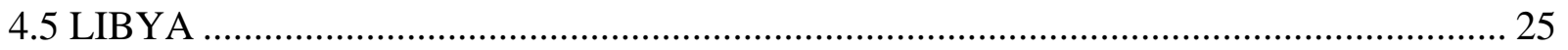

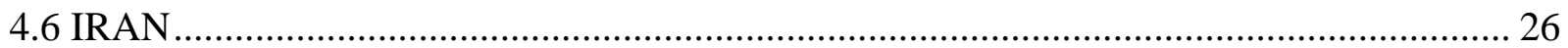

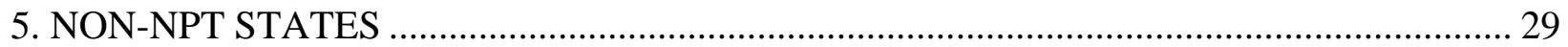

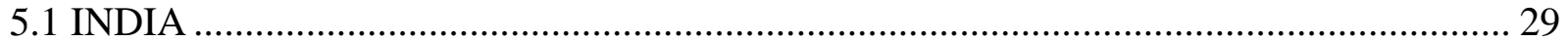

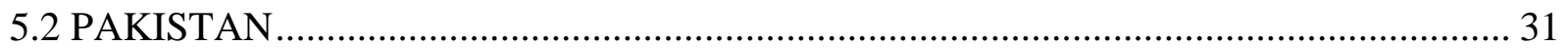

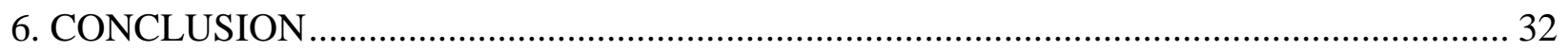

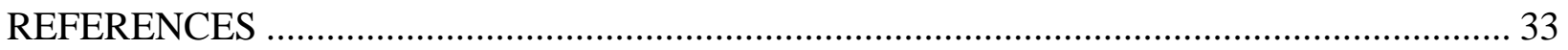





\section{LIST OF FIGURES}

Figure

Page

1 Alpha calutron track, Y-12 Plant, United States ..............................................................5

2 K-25 building at the now-dismantled Oak Ridge GDP, United States ................................6

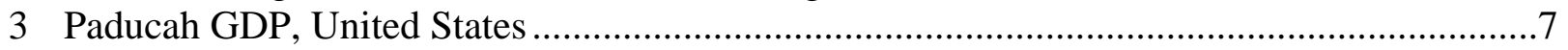

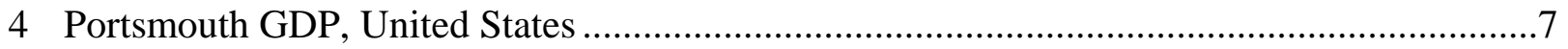

5 Gaseous diffusion cell, United States.......................................................................... 7

6 U.S. DOE centrifuges, United States ......................................................................

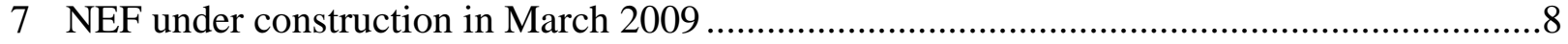

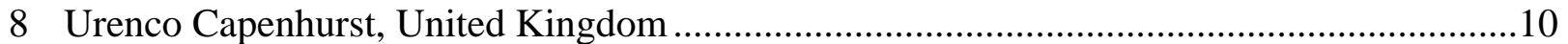

9 Novouralsk module 3, Russia..............................................................................11

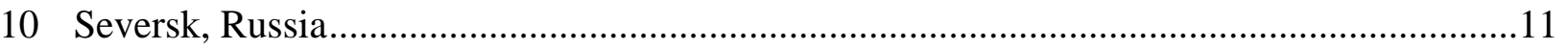

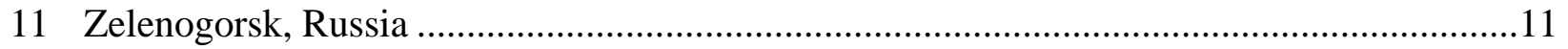

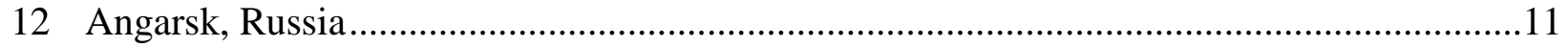

13 Novouralsk enrichment complex, Russia ..................................................................12

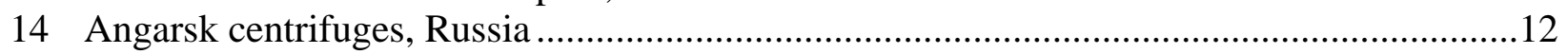

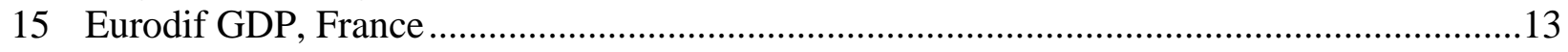

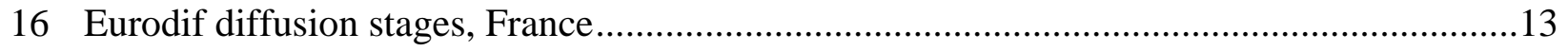

17 Georges Besse II plant under construction, March 2007 ...............................................13

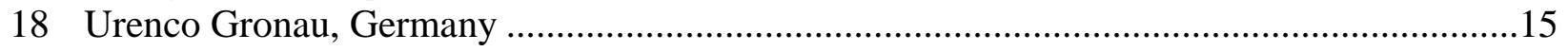

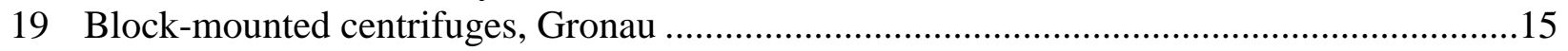

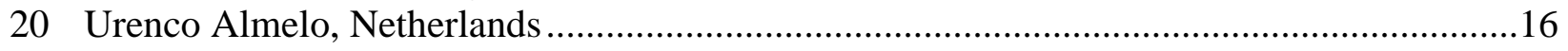

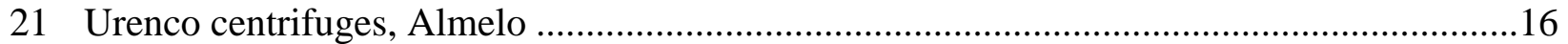

22 Rokkasho Uranium Enrichment Plant, Japan .............................................................17

23 Lucas Heights Science and Technology Centre, Australia ..............................................18

24 Aramar Experimental Center, Brazil ........................................................................20

25 Resende Nuclear Fuel Facility, Brazil ......................................................................20

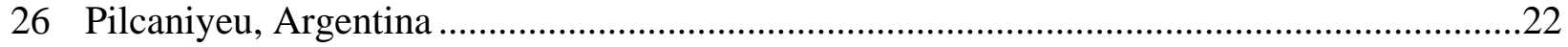

27 Argentine diffusers, Pilcaniyeu ................................................................................22

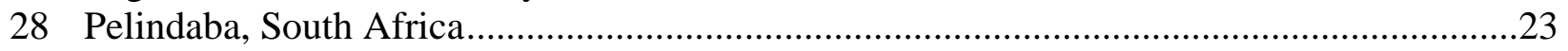

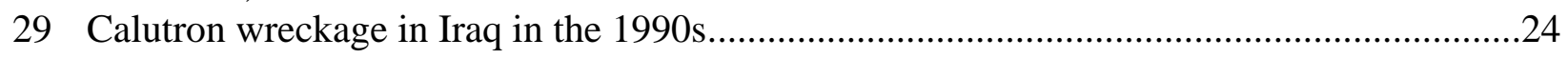

30 Centrifuges discovered in Iraq by IAEA inspectors in the 1990s ....................................25

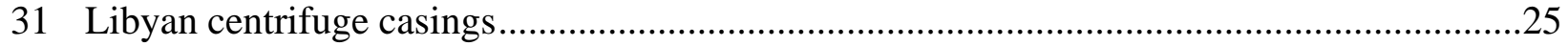

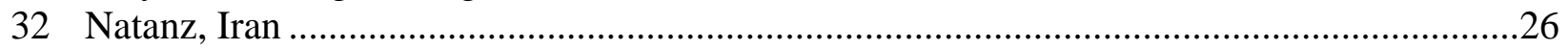

33 The 164-centrifuge cascade at the Natanz PFEP, Iran ..................................................27

34 Centrifuge installation and operation at Natanz FEP, Iran ............................................28

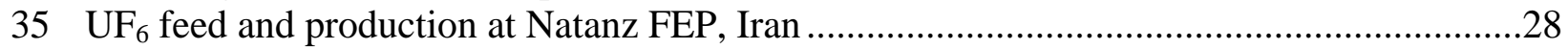

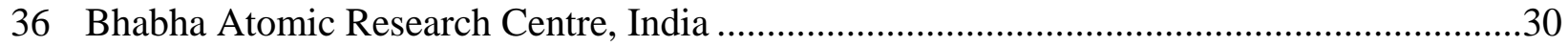

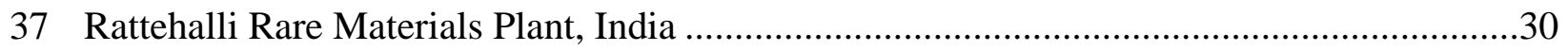

38 Khan Research Laboratory, Kahuta, Pakistan ..............................................................31

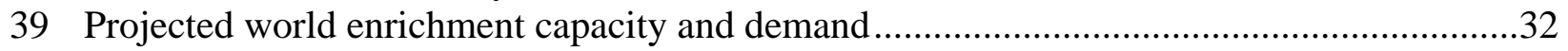





\section{LIST OF TABLES}

Table

Page

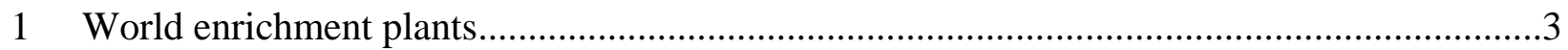

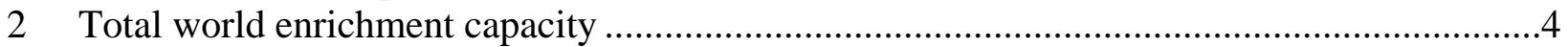

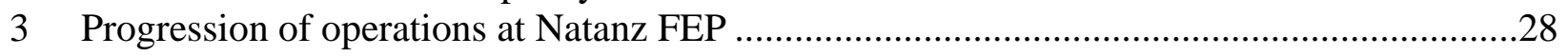





\section{ACRONYMS AND ABBREVIATIONS}

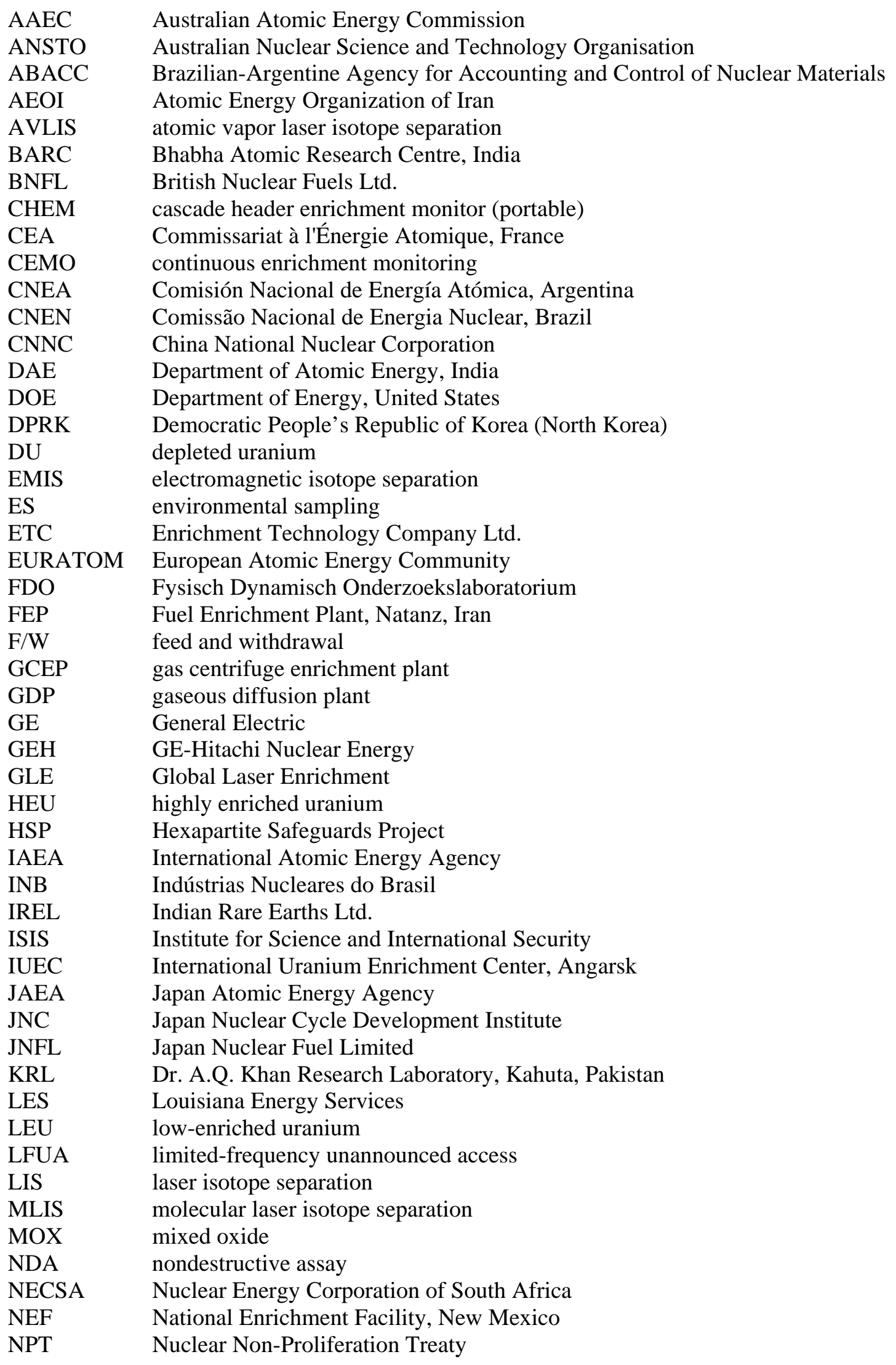




$\begin{array}{ll}\text { NRC } & \text { Nuclear Regulatory Commission, United States } \\ \text { NSG } & \text { Nuclear Suppliers Group } \\ \text { NWS } & \text { nuclear weapons state } \\ \text { ORNL } & \text { Oak Ridge National Laboratory } \\ \text { PAEC } & \text { Pakistan Atomic Energy Commission } \\ \text { PFEP } & \text { Pilot Fuel Enrichment Plant, Natanz, Iran } \\ \text { PNC } & \text { Power Reactor and Nuclear Fuel Development Corporation of Japan } \\ \text { PNPFC } & \text { Pakistan Nuclear Power Fuel Complex } \\ \text { Rosatom } & \text { Russian Federal Atomic Energy Agency } \\ \text { SILEX } & \text { Separation of Isotopes by Laser EXcitation } \\ \text { SWU } & \text { separative work unit } \\ \text { UF } & \text { uranium hexafluoride } \\ \text { U.K. } & \text { United Kingdom } \\ \text { U.S. } & \text { United States } \\ \text { USEC } & \text { United States Enrichment Corporation }\end{array}$

\section{ACKNOWLEDGMENTS}

The author would like to thank Allie Webb and Edie Carpenter of the Tennessee Governor's Academy for their help in collecting information for this report as part of their spring-semester research experience at ORNL. The author would like to thank the following people for reviewing and commenting on this report: from ORNL: Michael Whitaker, Len Phillips, Wayne Langenberg, and Danny Powell; from DOE: Dunbar Lockwood. The author would also like to thank, from ORNL, Amy Harkey for technical editing and Amy Hunt for assisting in getting this report cleared and published. 


\section{EXECUTIVE SUMMARY}

It is generally agreed that the most difficult step in building a nuclear weapon is acquiring fissile material, either plutonium or highly enriched uranium (HEU). Plutonium is produced in a nuclear reactor, whereas HEU is produced using a uranium enrichment process. Enrichment is also an important step in the civil nuclear fuel cycle, in producing low enriched uranium (LEU) for use as fuel for nuclear reactors to generate electricity. However, the same equipment used to produce LEU for nuclear reactor fuel can also be used to produce HEU for weapons. Safeguards at an enrichment plant are the array of assurances and verification techniques that ensure uranium is not diverted or enriched to HEU.

There are several techniques for enriching uranium. The two most prevalent are gaseous diffusion, which uses older technology and requires a lot of energy, and gas centrifuge separation, which uses more advanced technology and is more energy efficient. Gaseous diffusion plants (GDPs) provide about 40\% of current world enrichment capacity but are being phased out as newer gas centrifuge enrichment plants (GCEPs) are constructed. Estimates of current and future enrichment capacity are always approximate, due to the constant upgrades, expansions, and shutdowns occurring at enrichment plants, largely determined by economic interests. Currently, the world enrichment capacity is approximately 56 million kilogram separative work units (SWU) per year, with 22.5 million in gaseous diffusion and more than 33 million in gas centrifuge plants. Another 34 million SWU/year of capacity is under construction or planned for the near future, almost entirely using gas centrifuge separation. Other less-efficient techniques have also been used in the past, including electromagnetic and aerodynamic separations, but these are considered obsolete, at least from a commercial perspective. Laser isotope separation shows promise as a possible enrichment technique of the future but has yet to be demonstrated commercially.

In the early 1980s, six countries developing gas centrifuge technology (United States, United Kingdom, Germany, the Netherlands, Japan, and Australia) along with the International Atomic Energy Agency and the European Atomic Energy Community began developing effective safeguards techniques for GCEPs. This effort was known as the Hexapartite Safeguards Project (HSP). The HSP had the goal of maximizing safeguards effectiveness while minimizing the cost to the operator and inspectorate, and adopted several recommendations, such as the acceptance of limited-frequency unannounced access inspections in cascade halls, and the use of nondestructive assay measurements and tamper-indicating seals. While only the HSP participants initially committed to implementing all the measures of the approach, it has been used as a model for the safeguards applied to GCEPs in additional states.

Uranium enrichment capacity has continued to expand on all fronts in the last few years. GCEP capacity is expanding in anticipation of the eventual shutdown of the less-efficient GDPs, the termination of the U.S.-Russia HEU blend-down program slated for 2013, and the possible resurgence of nuclear reactor construction as part of an expected "Nuclear Renaissance." Overall, a clear trend in the world profile of uranium enrichment plant operation is the continued movement towards multinational projects driven by commercial and economic interests. Along this vein, the safeguards community is continuing to develop new safeguards techniques and technologies that are not overly burdensome to enrichment plant operators while delivering more effective and efficient results.

This report provides a snapshot overview of world enrichment capacity in 2009, including profiles of the uranium enrichment programs of individual states. It is a revision of a 2007 report on the same topic; significant changes in world enrichment programs between the previous and current reports are emphasized. It is based entirely on open-source information, which is dependent on published sources and may therefore not be completely accurate or reflect the most recent developments. Consequently, readers should not assume that information cited here has the endorsement of either ORNL or the U.S. Department of Energy. We are merely reporting what's been reported. In addition, this report briefly describes some of the safeguards techniques being used at various enrichment plants, including implementation of HSP recommendations. 



\section{INTRODUCTION}

It is generally agreed that the most difficult step in building a nuclear weapon is acquiring fissile material, either plutonium or highly enriched uranium (HEU). Plutonium is produced in a nuclear reactor, whereas HEU is produced using a uranium enrichment process. Enrichment is also an important step in the civil nuclear fuel cycle, in producing low-enriched uranium (LEU) for use as fuel for nuclear reactors to generate electricity. However, the same equipment used to produce LEU for nuclear reactor fuel can also be used to produce HEU for weapons. Safeguards at an enrichment plant are the array of assurances and verification techniques that ensure uranium is not diverted or enriched to HEU. This report provides a snapshot overview of world enrichment capacity in 2009, including profiles of the uranium enrichment programs of individual states, and describes some of the safeguards techniques being used at various enrichment plants. It is a revision of a 2007 report on the same topic; significant changes in world enrichment programs between the previous and current reports are emphasized. ${ }^{1}$ It is based entirely on open-source information, which is dependent on published sources and may therefore not be completely accurate or reflect the most recent developments. Consequently, readers should not assume that information cited here has the endorsement of either ORNL or the U.S. Department of Energy.

\subsection{UPDATES FROM 2007 REPORT}

Since the previous report in the Fall of 2007, construction has continued on several new gas centrifuge enrichment plants (GCEPs). Areva's Georges Besse II plant in France and Urenco's National Enrichment Facility in New Mexico (both using centrifuges from their jointly owned subsidiary Enrichment Technology Company Ltd. [ETC]) and United States Enrichment Corporation's (USEC’s) American Centrifuge Plant in Piketon, Ohio, are all nearer to completion. Areva's plans to build a GCEP in the United States have taken firmer shape: Areva has applied to the U.S. Nuclear Regulatory Commission (NRC) for a preliminary license to build a GCEP in Idaho called the Eagle Rock Enrichment Facility. Russia's effort to turn the Angarsk GCEP into an international fuel services center is continuing. Plans for expansion and modernization are progressing at the Rokkasho Uranium Enrichment Plant in Japan and at the Urenco GCEPs in Germany and the Netherlands. In addition to these large commercial facilities, Brazil and Iran have both made considerable progress in increasing capacity at their GCEPs—at Resende and Natanz, respectively_-by continuing to bring new cascades online. While it is clear that most expansion and construction in the near future will involve gas centrifuge technology, GE-Hitachi Nuclear Energy (GEH) has appeared to make some progress in its attempt to commercialize the SILEX laser enrichment process, forming a new subsidiary (along with Cameco) called Global Laser Enrichment (GLE) to build and run a plant near Wilmington, North Carolina.

Uranium enrichment capacity has continued to expand on all fronts in the last few years. GCEP capacity is expanding in anticipation of the eventual shutdown of the less-efficient gaseous diffusion plants (GDPs), the termination of the U.S.-Russia HEU blend-down program slated for 2013, and the possible resurgence of nuclear reactor construction as part of an expected "Nuclear Renaissance," which so far has not taken off at the rate many in the industry would hope. Several utilities in the United States have applied for preliminary licenses to build new reactors, and along with several other factors (e.g., continued reactor construction in Asia, especially China; the prospects for nuclear cooperation with India), this gives hope that a Nuclear Renaissance is still a possibility and that demand for uranium enrichment will continue to grow.

Overall, a clear trend in the world profile of uranium enrichment plants is the continued movement towards multinational projects. The "bloodlines" of centrifuge technology are essentially stable, but plant ownership and operation are continuing to shift to multinational consortia governed by commercial and economic — instead of national-interests. Future updates to this report may need to organize the sections along corporate, as opposed to national, lines. In keeping with this trend, the safeguards community is 
continuing to develop new safeguards techniques and technologies that are not overly burdensome to enrichment plant operators while delivering more effective and efficient results.

\subsection{ENRICHMENT OVERVIEW}

Enrichment is the process of concentrating the fissile isotope of natural uranium, ${ }^{235} \mathrm{U}(0.711 \%$ by weight in natural uranium). Higher concentrations of ${ }^{235} U$ make nuclear fission chain reactions easier to maintain. LEU (less than $20 \%{ }^{235} \mathrm{U}$ ) allows some nuclear reactor designs to produce sustained power for electricity production, while HEU (greater than $20 \%{ }^{235} \mathrm{U}$ ) allows the possibility that a chain reaction will exponentially increase, resulting in a nuclear explosion.

There are several techniques for enriching uranium. The two most prevalent are gaseous diffusion and gas centrifuge separation. Gaseous diffusion relies on the preferential permeability of ${ }^{235} \mathrm{U}$ through a porous membrane. It uses older technology, and the separation factor (increase in enrichment) of a single stage is very small. More than a thousand stages must be linked in cascades (the Georges Besse plant in France uses approximately 1400 stages to produce $\mathrm{LEU}^{2}$ ), requiring a lot of energy, a large amount of in-process uranium, and a long time to reach equilibrium. Gas centrifuge separation relies on the mass difference in the uranium isotopes to concentrate heavier isotopes at the edge of a rapidly spinning cylinder. It requires somewhat more advanced technology and materials, and the separation factor per centrifuge is greater, so fewer stages are required to make a cascade, making it more energy efficient. In addition, GCEP capacity can be increased simply by adding more centrifuge cascades in parallel, allowing expandability if needs change, whereas GDPs are not as flexible. Other less-efficient techniques have been used in the past, including electromagnetic and aerodynamic separations, but these are considered obsolete, at least from a commercial perspective. Laser isotope separation (LIS), using laser light to selectively ionize individual atoms (AVLIS—Atomic Vapor Laser Isotope Separation), ionize molecules (MLIS-Molecular Laser Isotope Separation), or excite molecules (SILEX-Separation of Isotopes by Laser EXcitation), shows promise as a cost-effective enrichment technique but has not yet been demonstrated commercially.

\subsection{WORLD ENRICHMENT CAPACITY}

Gaseous diffusion was initially the dominant process for providing enrichment services, and GDPs continue to provide about $40 \%$ of current world enrichment capacity. However, these older plants are being phased out as newer GCEPs are constructed. Estimates of current and future enrichment capacity are always approximate due to the constant upgrades, expansions, and shutdowns occurring at enrichment plants, largely determined by economic interests. In addition, most plants are not continuously operated at their maximum capacities. In general, capacity does not equate directly with actual production. Table 1 gives a summary of current and planned capacity at world enrichment plants. All of the values are referenced in this report, in the text of the appropriate section for each state. The capacity for plants listed as "shut down" or "dismantled" is the maximum capacity the plant was designed for when it was operating. For plants listed as "operating/under construction," the capacity is the total design capacity; often, cascades are put into operation as they are completed.

Currently, the world enrichment capacity is approximately 55.7 million kilogram separative work units (kg SWU, often referred to merely as SWU in this report) per year, with 22.5 million in gaseous diffusion and 33.2 million in gas centrifuge plants (Table 2). Plants to produce another 33.9 million SWU/year are under construction or planned for the near future, almost entirely using gas centrifuge separation. This report only discusses enrichment facilities that use isotope separation processes to produce uranium enriched in ${ }^{235} \mathrm{U}$. A large proportion of world demand for LEU fuel is currently being met by downblending excess weapons-grade HEU, ${ }^{3}$ and this capacity is often reported as "SWU-equivalent," meaning the enrichment capacity that would be required to produce an equivalent amount of LEU. Mixed oxide (MOX) fuel, produced by mixing reprocessed plutonium with uranium, is also sometimes measured in SWU equivalents and adds to the total world SWU supply. 
Table 1. World enrichment plants

\begin{tabular}{|c|c|c|c|c|c|}
\hline State & Plant Name/Location & Owner/Operator & Type & Status & $\begin{array}{l}\text { Capacity } \\
\text { (kg SWU/year) }\end{array}$ \\
\hline Argentina & Pilcaniyeu & CNEA & Gaseous diffusion & Standby/planned & 20,000 \\
\hline Australia & Lucas Heights & AAEC & Centrifuge & Shutdown/dismantled & Laboratory \\
\hline \multirow[t]{2}{*}{ Brazil } & Aramar & Brazilian Navy, CNEN & Centrifuge & Operating & 9,000 \\
\hline & Resende & INB & Centrifuge & Operating/under construction & 120,000 \\
\hline \multirow[t]{5}{*}{ China } & Heping & CNNC & Gaseous diffusion & Operating & 400,000 \\
\hline & Lanzhou & CNNC & Gaseous diffusion & Shut down & 500,000 \\
\hline & Shaanxi-Hanzhong & CNNC & Centrifuge & Operating & 500,000 \\
\hline & Lanzhou & CNNC & Centrifuge & Operating & 500,000 \\
\hline & Phase 4 (Hanzhong or Lanzhou) & CNNC & Centrifuge & Planned & 500,000 \\
\hline \multirow[t]{3}{*}{ France } & Pierrelatte GDP & CEA & Gaseous diffusion & Shut down & 500,000 \\
\hline & Georges Besse-Tricastin & Eurodif & Gaseous diffusion & Operating & $10,800,000$ \\
\hline & Georges Besse II-Tricastin & Areva & Centrifuge & Under construction & $7,500,000$ \\
\hline \multirow[t]{2}{*}{ Germany } & Gronau & Urenco & Centrifuge & Operating & $2,200,000$ \\
\hline & & & & Planned & $2,300,000$ \\
\hline \multirow[t]{2}{*}{ India } & BARC, Trombay & DAE & Centrifuge & Operating & Pilot \\
\hline & $\begin{array}{l}\text { Rattehalli Rare Materials Plant, } \\
\text { Mysore }\end{array}$ & IREL/DAE & Centrifuge & Operating & $4-10,000$ \\
\hline \multirow[t]{2}{*}{ Iran } & Natanz PFEP & AEOI & Centrifuge & Operating & Pilot \\
\hline & Natanz FEP & AEOI & Centrifuge & Operating/under construction & 250,000 \\
\hline \multirow[t]{3}{*}{ Japan } & Ningyo-Toge Pilot \& Demo & JAEA & Centrifuge & Shut down & 250,000 \\
\hline & Rokkasho & JNFL & Centrifuge & Operating & 150,000 \\
\hline & & & & Planned & $1,350,000$ \\
\hline \multirow[t]{2}{*}{ Netherlands } & Almelo & Urenco & Centrifuge & Operating & $3,800,000$ \\
\hline & & & & Planned & 700,000 \\
\hline \multirow[t]{2}{*}{ Pakistan } & KRL Kahuta & PAEC & Centrifuge & Operating & $15-20,000$ \\
\hline & Unconfirmed plant, Kundian & PAEC & Centrifuge & Planned & Unknown \\
\hline \multirow[t]{5}{*}{ Russia } & $\begin{array}{l}\text { Urals ElectroChemical Combine- } \\
\text { Novouralsk }\end{array}$ & Rosatom & Centrifuge & Operating & $9,800,000$ \\
\hline & $\begin{array}{l}\text { Siberian Chemical Combine- } \\
\text { Seversk }\end{array}$ & Rosatom & Centrifuge & Operating & $2,800,000$ \\
\hline & Zelenogorsk ElectroChemical Plant & Rosatom & Centrifuge & Operating & $5,800,000$ \\
\hline & $\begin{array}{l}\text { Angarsk ElectroChemical } \\
\text { Combine-International Uranium } \\
\text { Enrichment Center }\end{array}$ & Rosatom & Centrifuge & Operating & $2,600,000$ \\
\hline & $\begin{array}{l}\text { Uranium Enrichment Center- } \\
\text { Angarsk }\end{array}$ & Rosatom/Kazatomprom & Centrifuge & Planned & $5,000,000$ \\
\hline \multirow[t]{2}{*}{ South Africa } & Z-Plant_-Pelindaba & NECSA & Aerodynamic & Shut down/dismantled & 300,000 \\
\hline & Y-Plant_-Valendaba & NECSA & Aerodynamic & Shut down/dismantled & 10,000 \\
\hline \multirow[t]{2}{*}{ United Kingdom } & Capenhurst & BNFL & Gaseous diffusion & Shut down & 350,000 \\
\hline & & Urenco & Centrifuge & Operating & $5,000,000$ \\
\hline \multirow[t]{9}{*}{ United States } & Oak Ridge GDP & U.S. DOE & Gaseous diffusion & Shut down & $8,500,000$ \\
\hline & Paducah & USEC & Gaseous diffusion & Operating & $11,300,000$ \\
\hline & Portsmouth & USEC & Gaseous diffusion & Standby & $7,400,000$ \\
\hline & National Enrichment Facility & Urenco & Centrifuge & Under construction & $5,900,000$ \\
\hline & Lead Cascade, Piketon & USEC & Centrifuge & Under construction & Pilot \\
\hline & American Centrifuge Plant, Piketon & USEC & Centrifuge & Planned & $3,800,000$ \\
\hline & Eagle Rock Enrichment Facility & Areva & Centrifuge & Pre-licensing & $3,300,000$ \\
\hline & SILEX Test Loop, Wilmington & GLE & Laser & Under construction & Pilot \\
\hline & GLE (SILEX) Plant, Wilmington & GLE & Laser & Pre-licensing & $3.5-6,000,000$ \\
\hline
\end{tabular}


Table 2. Total world enrichment capacity (in millions of kilogram separative work units per year)

\begin{tabular}{lcc}
\hline & Operating & Planned/under construction \\
\hline Gas centrifuge & 33.2 & 30.7 \\
Gaseous diffusion & 22.5 & 0.02 \\
Laser isotope separation & - & (planned restart of Pilcaniyeu) \\
Total & $\mathbf{5 5 . 7}$ & $3.5-6$ \\
\hline
\end{tabular}

\subsection{THE HEXAPARTITE SAFEGUARDS PROJECT}

In the early 1980s, six countries with gas centrifuge technology (United States, United Kingdom, Germany, the Netherlands, Japan, and Australia) along with the International Atomic Energy Agency (IAEA) and the European Atomic Energy Community (EURATOM) began investigating effective safeguards techniques for GCEPs. This effort was known as the Hexapartite Safeguards Project (HSP). The HSP had four specific objectives for maximizing effectiveness and efficiency: ${ }^{4}$

1. Maximize safeguards (verification) effectiveness,

2. Minimize the risk of acquiring sensitive information and technology by the inspectorate,

3. Minimize the intrusiveness and cost to facility operators, and

4. Minimize inspectorate resource requirements to carry out the verification.

The HSP reached a consensus that HEU production was a greater proliferation risk than LEU diversion and focused verification techniques on the detection of HEU. The project adopted several recommendations, including the acceptance of random limited-frequency unannounced access (LFUA) to cascade halls, the necessity of inspector access to cascade halls within 2 hours of the request (2 hours was considered long enough for the operator to protect proprietary information but not long enough to remove all evidence of illicit activity), and the use of nondestructive assay (NDA) measurements and tamperindicating seals.

While only the HSP participants initially committed to implementing all the measures of the approach, it has been used as a model for the safeguards applied to GCEPs in additional states. The IAEA investigates new measures and incorporates new technologies as the techniques and implementation of safeguards continue to evolve. This includes expanding its authority by implementing strengthened safeguards and encouraging states to adopt an Additional Protocol, and integrating advanced technologies to assist in better meeting the HSP goal of detecting diversion or misuse of declared material at declared facilities. Additional measures, such as environmental sampling (ES) and wide-area monitoring, provide some capability to detect undeclared feeds, materials, and activities, which were all beyond the scope of the original HSP.

Safeguards experts and enrichment plant operators recently have begun working on an update of the HSP, dubbed colloquially by some "HSP+." It has become clear that the model safeguards approach of the HSP, which focused on HEU production, is labor intensive and would be expensive to implement at the larger-capacity facilities being constructed and operated today. Also, there are now more GCEP operators and more centrifuge technology holders (e.g., China, France, Brazil, Iran) that did not participate in the original HSP in the 1980s. An HSP+ process could bring these stakeholders together with the IAEA to (1) examine the safeguards techniques and technologies developed by the IAEA and safeguards community over the past 25 years, (2) analyze the diversion scenarios possible with large GCEPs and modern centrifuges, and (3) recommend the most effective and efficient advanced safeguards methods to deter such activities. 


\section{P-5 STATES}

The Nuclear Non-Proliferation Treaty (NPT) recognizes five nuclear weapons states (NWSs), those that "manufactured and exploded a nuclear weapon or other nuclear explosive device prior to January 1 , 1967"': United States, United Kingdom, Russia, France, and China. These states are also the five permanent members of the United Nations Security Council, designated the "P-5." The NWSs are not required under the NPT to have their nuclear facilities and material safeguarded by the IAEA. However, they can designate some facilities and material to be put under safeguards as part of a "voluntary offer," to demonstrate to non-nuclear weapons states "that they would not be placed at a commercial disadvantage by reason of the application of safeguards." " In addition, a supplier state can require that nuclear material from that state be put under safeguards as a condition of exporting to an NWS (e.g., Australia's conditions on selling uranium to China). ${ }^{7}$

\subsection{UNITED STATES}

The United States implemented uranium enrichment on an industrial scale as part of the Manhattan Project to build a nuclear weapon during World War II. The first techniques used were thermal diffusion, which was quickly abandoned, and electromagnetic isotope separation (EMIS), where ionized atoms are separated by traveling through a strong magnetic field. Large EMIS machines called calutrons were built at the Oak Ridge Y-12 Plant and supplied the HEU for the United States' first weapon (Fig.1). By the end of the war in 1945, a GDP process building designated K-25 (Fig. 2) had been constructed at Oak Ridge with a capacity of about 100,000 SWU/year. Over the next 10 years additional process buildings were built at the site, which continued to be referred to as "K-25" although strictly this only refers to the first process building. The whole facility was the Oak Ridge GDP, which reached a maximum capacity of 8.5 million SWU/year in the early 1980s through numerous equipment improvements and power supply increases. $^{8}$

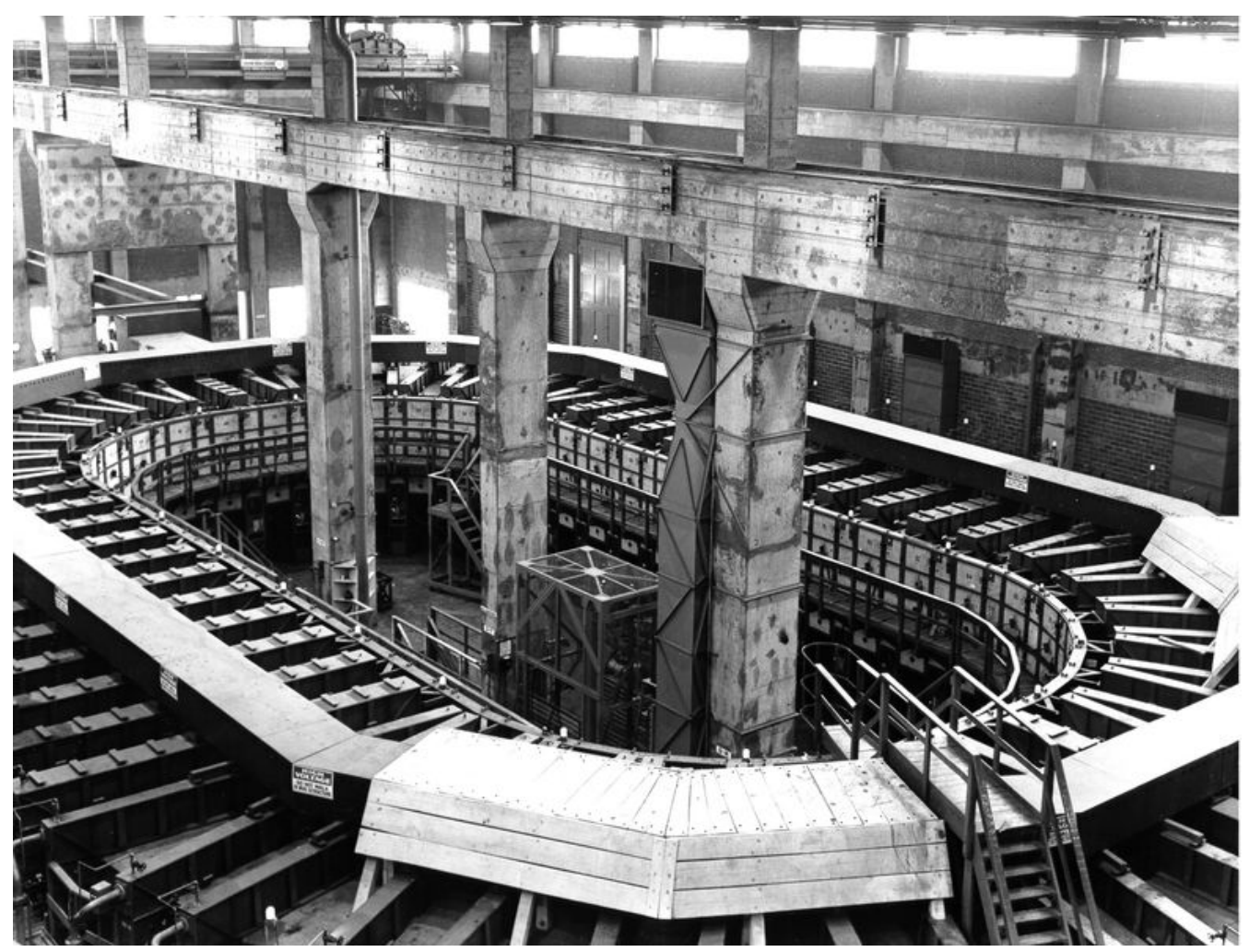

Fig. 1. Alpha calutron track, Y-12 Plant, United States. 
In the 1950s, the United States constructed two more large GDPs to increase production capacity: one at Paducah, Kentucky (Fig. 3) that first produced enriched uranium in 1952 and was completed in 1954 (maximum capacity in the 1980s of 11.3 million SWU/year), the other at Piketon, Ohio (Fig. 4), near Portsmouth that went online in 1956 (maximum capacity in the 1980s of 7.4 million SWU/year). In the 1960s the United States ceased enriching uranium for weapons and began producing LEU for commercial power plants, in addition to continuing to produce HEU for fuel for research reactors and nuclear submarines. The Oak Ridge GDP continued producing LEU for commercial power plants until it was shut down in 1985. It has since been almost entirely decommissioned and dismantled. The Portsmouth GDP produced HEU for research reactors and submarines until the "top end" was shut down in the early 1990s, but continued to produce LEU until the rest of the plant was put on standby in 2001. All current uranium enrichment in the United States takes place at the Paducah GDP, ${ }^{9}$ which currently operates at about two-thirds capacity due to power supply limitations.

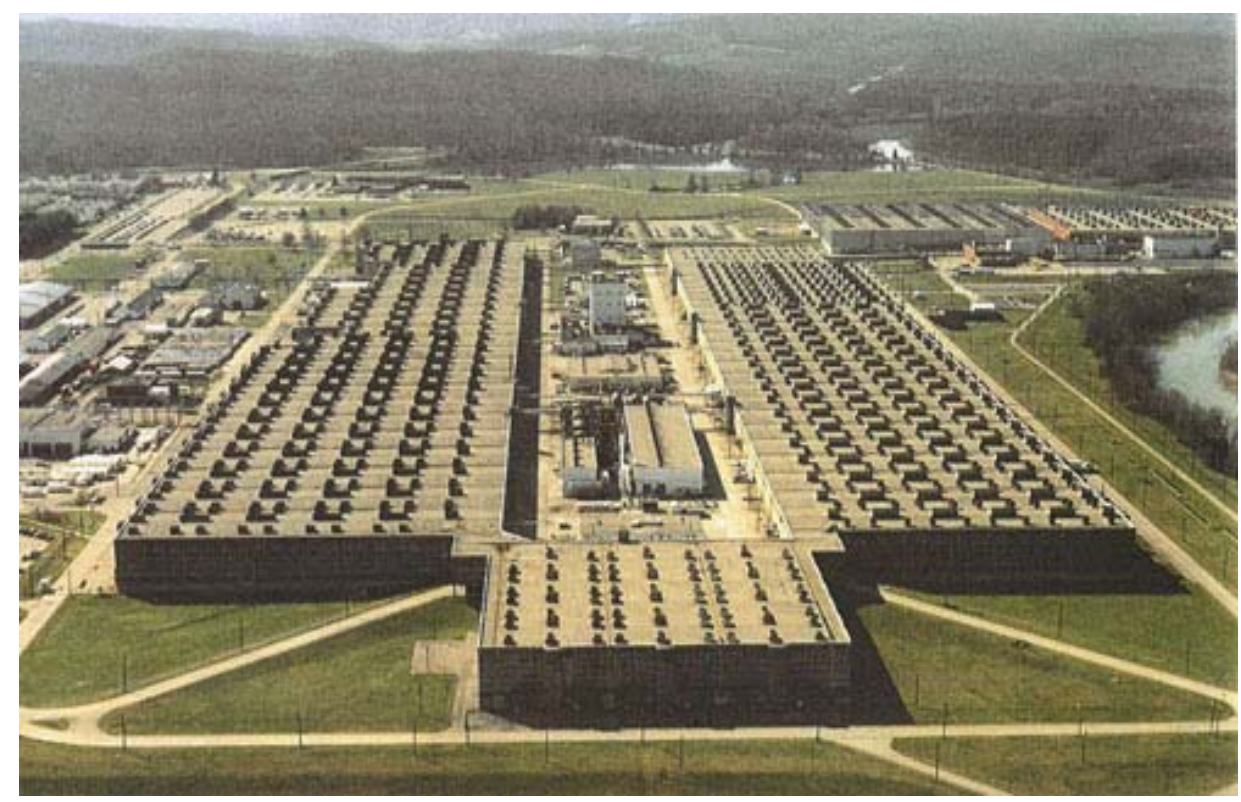

Fig. 2. K-25 building at the now-dismantled Oak Ridge GDP, United States.

In the 1960s the U.S. Atomic Energy Commission, predecessor to the Department of Energy (DOE), began investigating centrifuge enrichment, and in the 1970s and 1980s developed an advanced centrifuge design and began constructing a GCEP near its GDP in Piketon, Ohio. More than 1300 centrifuges had been installed at the facility by 1985, when the project was shut down. Finishing and operating the plant seemed uneconomical, because SWU demand had fallen short of earlier projections and was being met by the GDPs. In addition, the United States had decided to refocus research and development efforts on AVLIS technology, ${ }^{10}$ work that was suspended in 1999. ${ }^{11}$ These centrifuges were stored until 2006 (Fig. 6), when they were dismantled. ${ }^{12}$

\section{USEC GCEP}

USEC, the current operator of the Paducah GDP and the at-standby Portsmouth GDP, has been constructing since May 2007 a GCEP called the American Centrifuge Plant at the Portsmouth site, in the building that originally housed the DOE centrifuge project in the 1980s. The USEC centrifuge design (designated the AC100) is also based largely on the DOE design from that project. USEC has constructed a "Lead Cascade" demonstration facility; testing of individual centrifuges with $\mathrm{UF}_{6}$ and initial integrated cascade testing has taken place. ${ }^{13}$ The AC100 centrifuge design has continued to be modified based on the 
results of this testing and manufacturing refinements, and USEC now reports that individual centrifuges have "demonstrated machine productivity beyond 350 SWU per year." USEC expects the Lead Cascade to enter full operation in 2009, and the first cascades in the commercial plant to begin operating early in 2010, with plans for 1 million SWU/year capacity in 2011 and full capacity of 3.8 million SWU/year by the middle of 2013, although this schedule will likely be modified to reflect current economic conditions. ${ }^{14,15}$

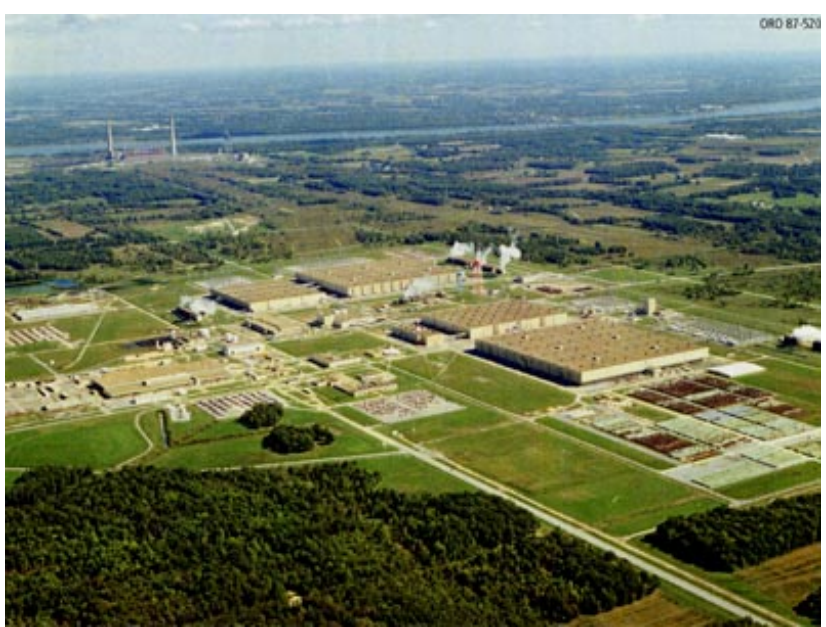

Fig. 3. Paducah GDP, United States.

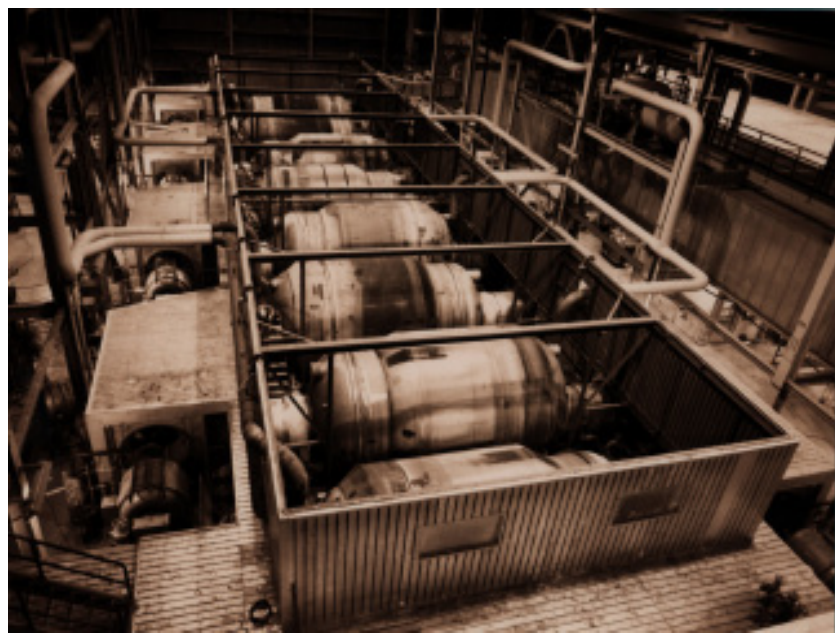

Fig. 5. Gaseous diffusion cell, United States.

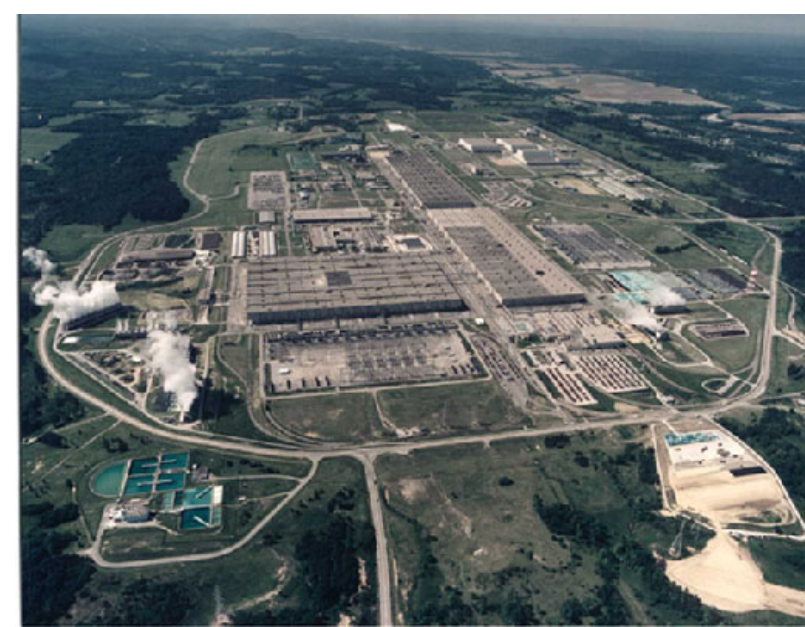

Fig. 4. Portsmouth GDP, United States.

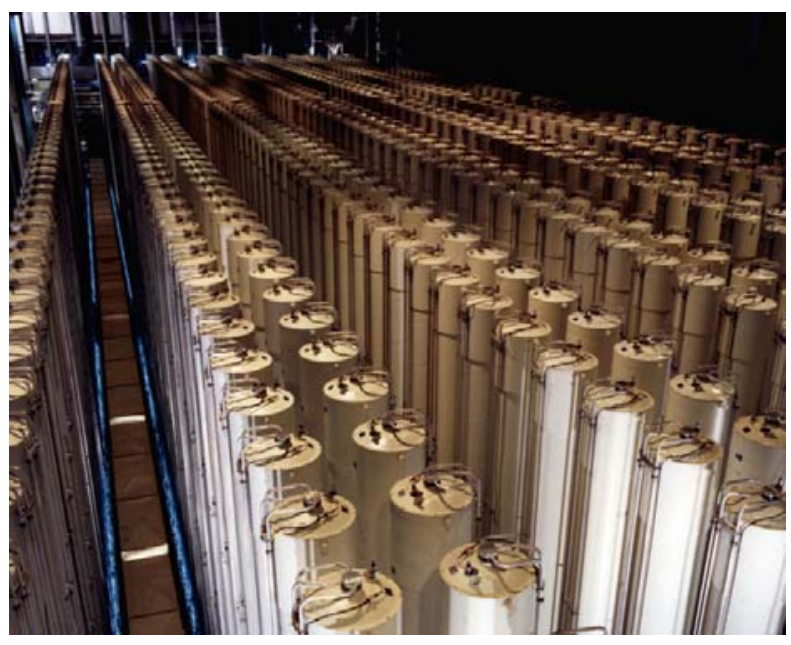

Fig. 6. U.S. DOE centrifuges, United States.

\section{Other GCEPs}

Urenco, through a subsidiary called Louisiana Energy Services (LES), was licensed by the NRC in June 2006 to build a GCEP in the United States ${ }^{16}$ and began construction on the National Enrichment Facility (NEF) (Fig. 7) near Eunice, New Mexico, in August 2006. ${ }^{17}$ The license authorizes LES to produce LEU up to $5 \%{ }^{235} \mathrm{U}$ for use as nuclear fuel in commercial power plants. ${ }^{18}$ The NEF was initially going to have a total capacity of 3 million SWU/year, but in November 2008 Urenco announced that it was moving forward with plans to expand the capacity to 5.9 million SWU/year, using more advanced centrifuges (model TC-21) than in the original phase (TC-12). The plant is expected to start initial operation in 2009, with full capacity reached at the end of $2014 .{ }^{19,20}$ The first $\mathrm{UF}_{6}$ - to be used for testing in the completed centrifuge assembly building — arrived at the site in February 2009. ${ }^{21}$ 
In May 2007 Areva held a pre-application meeting with the NRC on constructing a 3.3 million SWU/year GCEP in the United States. Like the NEF and the Georges Besse II plants under construction, this plant will use ETC centrifuges. The project is in the planning phase, but Areva plans to start construction in 2011 and begin initial operation by $2014 .{ }^{22}$ In May 2008 Areva selected a site for the plant in Idaho near the Idaho National Laboratory, ${ }^{23}$ and in July 2008 announced that the GCEP will be called the Eagle Rock Enrichment Facility. ${ }^{24}$ In December 2008 Areva submitted a license application for the facility to the NRC and formed a new subsidiary called Areva Enrichment Services LLC to operate the Eagle Rock GCEP. ${ }^{25,26}$ In March 2009, Areva informed the NRC that it intends to revise the application to allow the possibility of doubling the capacity to 6.6 million SWU/year if market conditions justify such a decision. The possible expansion would involve constructing additional separations buildings in the 2020 time frame, after the initial 3.3 million SWU/year facility enters full production around $2018 .{ }^{27}$

Russian nuclear officials have also expressed some interest in constructing a GCEP in the United States based on Russian centrifuge technology and are said to be "looking for serious proposals" from potential U.S. partners. ${ }^{28,29}$

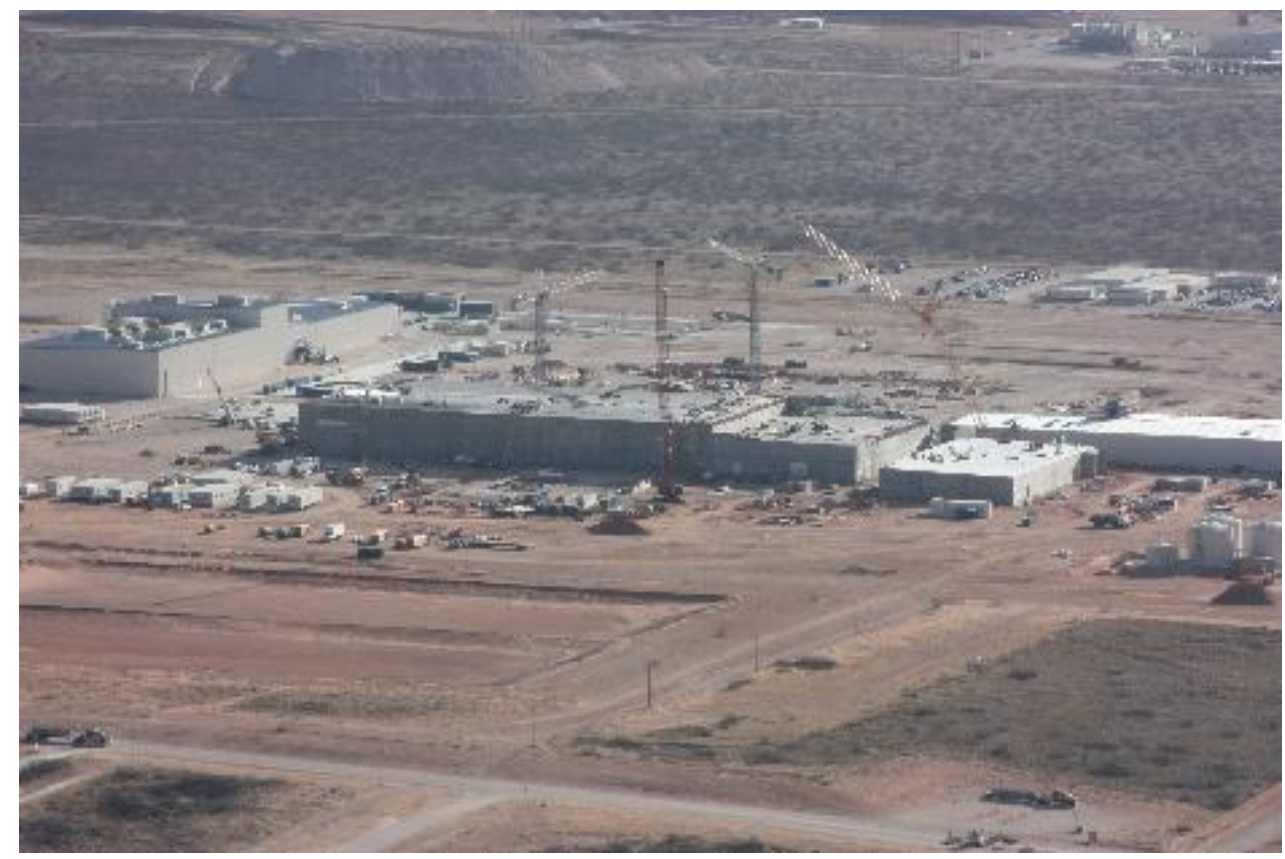

Fig. 7. NEF under construction in March 2009. Source: urenco.com

\section{Laser Enrichment}

A laser isotope separation process called SILEX (Separation of Isotopes by Laser EXcitation) has been developed by Silex Systems Limited at the Lucas Heights Science and Technology Centre in Australia. In 1996 USEC secured the rights to evaluate and develop SILEX for commercial uranium enrichment. In May 2000, President Clinton and the U.S. Congress approved a U.S.-Australian agreement for cooperation on the development of SILEX technology. In June 2001 SILEX technology was officially classified by the U.S. and Australian governments, bringing the project formally under the security and regulatory protocols of each country.

USEC relinquished its rights in 2003, and Silex signed a "Commercialization and License Agreement" with General Electric (GE) in May 2006. ${ }^{30}$ In October 2006 Silex announced that it and GE have received U.S. government authorization to proceed with an agreement granting GE exclusive rights to develop and 
commercialize SILEX uranium enrichment technology. The SILEX process is also being used in Australia to enrich lighter elements, such as silicon and zirconium. The uranium enrichment application of SILEX is currently in the final stage, the "Test Loop" phase, of a three-stage development program. The Test Loop is being constructed at GE's fuel fabrication facility in Wilmington, North Carolina, to simulate a full-scale facility for performance and reliability verification.

GE and Japan-based Hitachi formed a joint venture of their nuclear businesses-GE-Hitachi Nuclear Energy (GEH) - in early 2007. GEH encompasses the power reactor and fuel cycle operations of both companies, including the SILEX project in Wilmington. ${ }^{31}$ In early 2008, GEH formed a new subsidiary called Global Laser Enrichment (GLE) to manage all aspects of the commercialization of SILEX technology. In June 2008 Cameco acquired a 24\% stake in GLE. ${ }^{32}$ This will allow Cameco to market enrichment services along with its uranium mining, conversion, and fuel fabrication capabilities.

The Test Loop facility received an operating license from the NRC in May 2008. After successful completion of the Test Loop stage, planned for late 2009, licensing and construction will begin on the "Lead Cascade" commercial production plant. GLE plans to submit its license application for the commercial facility to NRC in June 2009..$^{33}$ GLE has also selected the Wilmington site to host the commercial plant; a final decision to proceed with construction is expected in 2009, with commercial operation beginning as early as $2012 .{ }^{34}$ Projections by GLE state that the eventual commercial SILEX facility in the United States will have a capacity of between 3.5 million and 6 million SWU/year, ${ }^{35}$ and several nuclear utilities (e.g., Exelon, Entergy) have signed nonbinding letters of intent to contract for enrichment services when the commercial facility becomes operational. ${ }^{36}$

\subsection{UNITED KINGDOM}

The United Kingdom constructed a GDP near Capenhurst. The plant had a maximum capacity of approximately 350,000 SWU/year and began operation in $1953 .{ }^{37}$ British Nuclear Fuels Ltd. (BNFL) took control of the plant in 1971, and it was shut down in 1982. Full decommissioning is expected to be completed in $2009 .{ }^{38}$

BNFL began construction of a GCEP at Capenhurst in 1973. A 200,000 SWU/year demonstration plant (designated E21) began operation in 1976, was completed in 1980, and was shut down in 2000. A larger facility, E22, was started in 1982 and ultimately increased the site capacity to 1 million SWU/year. In 1985, the facility A3 was constructed to provide enrichment for defense needs. The facility A3 was later converted to commercial enrichment. Urenco took full ownership of the GCEP at Capenhurst in 1993. The E23 facility began operating in 1997 and is continuing to add capacity-the $80^{\text {th }}$ cascade came online in October 2008, and E23 is only four cascades away from completion. The entire site capacity was 5 million SWU/year at the end of $2008 .{ }^{39,40}$

All of the HSP measures have been implemented at the Capenhurst facility (Fig. 8). Inspections are performed jointly by the IAEA and EURATOM. Following Program 93+2, the United Kingdom accepted ES as a Part 1 strengthening measure. Capenhurst has also allowed continuous (on-line) enrichment monitoring (CEMO) since about 1995. The CEMO system transmits a simple go/no-go message daily to the IAEA, indicating that the system is operating properly and the measured enrichment is within the bounds of the declaration. If the CEMO transmits that something is out of the ordinary, an inspector must be sent to determine what the problem is. In the early 1990s, the British Support Program to the IAEA installed the CEMO system for the product header pipes. Prior to that, the United Kingdom allowed the IAEA to measure enrichment (again with go/no-go determination only) with a portable germanium detector acting as a cascade header enrichment monitor (CHEM), but only at a U.K.-selected location outside the cascade hall. The CEMO systems have been installed on product header pipes at the facility and provide data directly to IAEA Headquarters in Vienna via a remote data transfer. 


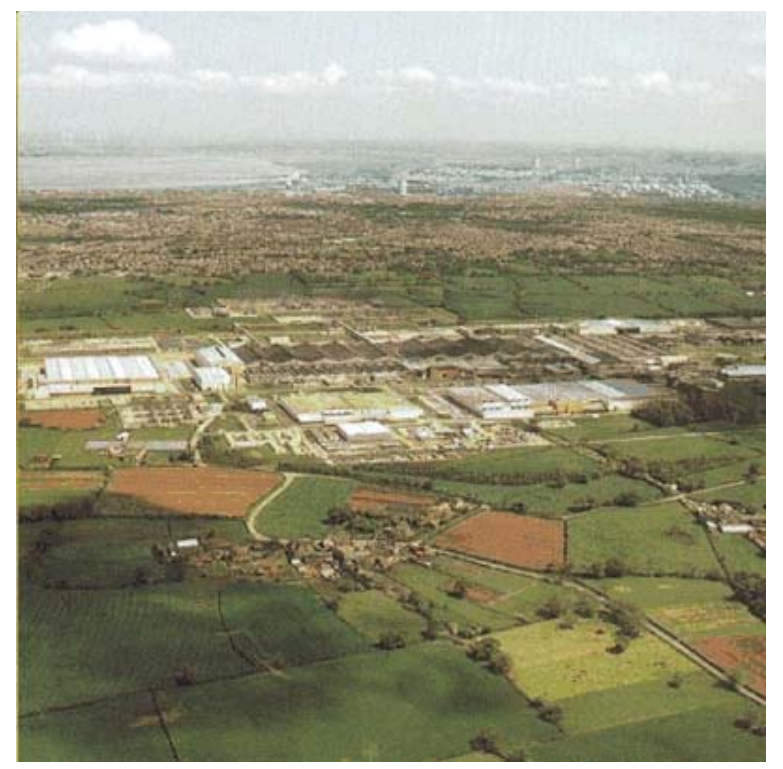

Fig. 8. Urenco Capenhurst, United Kingdom. Source: GlobalSecurity.org

The British have stated that they developed this system in recognition that future cascade designs would be much more dynamic and flexible. Video surveillance cameras are installed in locations that are not visually accessible for LFUAs. Although the GDP at Capenhurst has been completely dismantled, the remnants of past HEU production are still detectable by the ES activities at the adjacent centrifuge facility. $^{41}$

\subsection{RUSSIA}

The Russian effort to enrich uranium started immediately after World War II. Russia (the Soviet Union, at that time) began using gaseous diffusion technology but refocused on gas centrifuge enrichment much earlier than the United States, opening its first industrial centrifuge facility in the early 1960s. Russian innovation in the early 1950s led directly to some of the principles of centrifuge design (magnetic bearings, stationary scoops, short, subcritical rotors, etc.) widely used today by Russia, Urenco, and others. In the 1970s and 1980s, Russia replaced all of its gaseous diffusion equipment with several generations of centrifuges; the pre-assembling of 20-machine "aggregates" (Fig. 14) by the manufacturers allowed centrifuges to be rapidly installed in former gaseous diffusion buildings. The Russian centrifuge program is run by state-owned Tekhsnabexport, now a subsidiary of Atomenergoprom, a company created in 2007 as an umbrella organization for the Russian civil nuclear industry. Russia is operating plants at four sites (indicated capacities are approximate; actual capacities are changing rapidly as older centrifuges are replaced with newer models): (1) the Urals ElectroChemical Combine in Novouralsk, formerly referred to as Sverdlovsk-44, near Ekaterinburg (9.8 million SWU/year); (2) the Siberian Chemical Combine in Seversk, formerly Tomsk-7 (2.8 million SWU/year); (3) the ElectroChemical Plant in Zelenogorsk, formerly Krasnoyarsk-45 (5.8 million SWU/year); and (4) the Angarsk ElectroChemical Combine (2.6 million SWU/year). Russia's four plants (Figs. 9-13) account for approximately $40 \%$ of the world's operating enrichment capacity. Russia is continuing to increase its enrichment capacity by upgrading centrifuges to $7^{\text {th }}$-, $8^{\text {th }}$-, and $9^{\text {th }}$-generation designs; the capacity is expected to reach 25 million SWU/year by 2010 and will continue to increase as older centrifuges reach the end of their design life and are replaced. ${ }^{42}$

Russia has designated the enrichment plant at Angarsk the International Uranium Enrichment Center (IUEC), which will be open to foreign investment. So far, Kazakhstan has taken a 10\% share in the center; several other countries are reported to be interested (e.g., Armenia, Ukraine, Bulgaria, Belgium), 
but none have yet officially taken a stake. ${ }^{43}$ In addition, Kazakhstan and Russia have agreed to cooperate in financing a new 5 million SWU/year GCEP at the Angarsk site. ${ }^{44}$ Kazakhstan will receive $50 \%$ of the eventual output from this plant, called Uranium Enrichment Center, in order to "add value” to its current uranium exports. Construction on this new plant is expected to start sometime in 2009, with operation of the first 1 million SWU/year stage in $2011^{45}$

Russia currently has more enrichment capacity than is required for domestic fuel production, and export demand for LEU is insufficient to utilize the rest of the capacity. Therefore, since the mid-1990s, Russia has been accepting depleted uranium tails from Urenco and Areva for re-enrichment, producing naturalequivalent uranium and lower-assay tails, as well as some slightly enriched uranium to use as downblending feedstock, with its surplus enrichment capacity. ${ }^{46}$ This helps to supplement Russia's limited natural uranium supply (due largely to the loss of Kazakhstan's uranium reserves after the breakup of the Soviet Union). However, Rosatom has announced that it is phasing out re-enrichment of depleted uranium (DU) in anticipation of increased world demand of enrichment for LEU production and other economic concerns. ${ }^{47}$

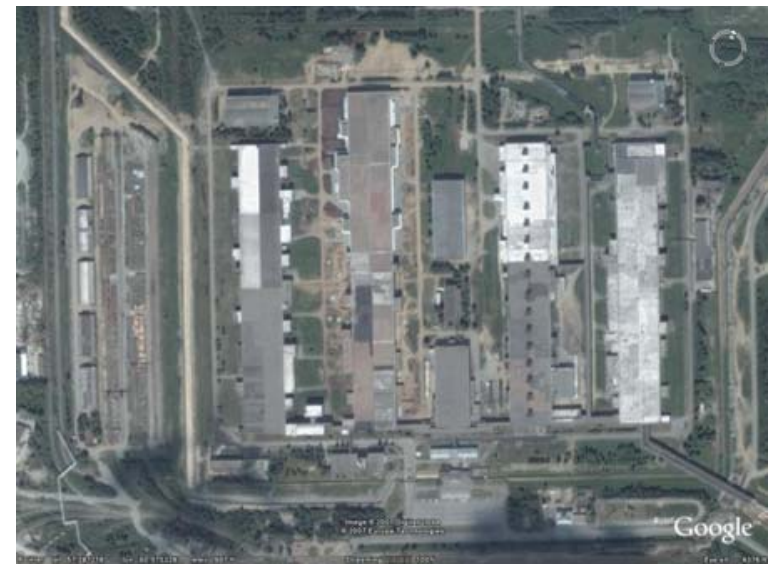

Fig. 9. Novouralsk module 3, Russia.

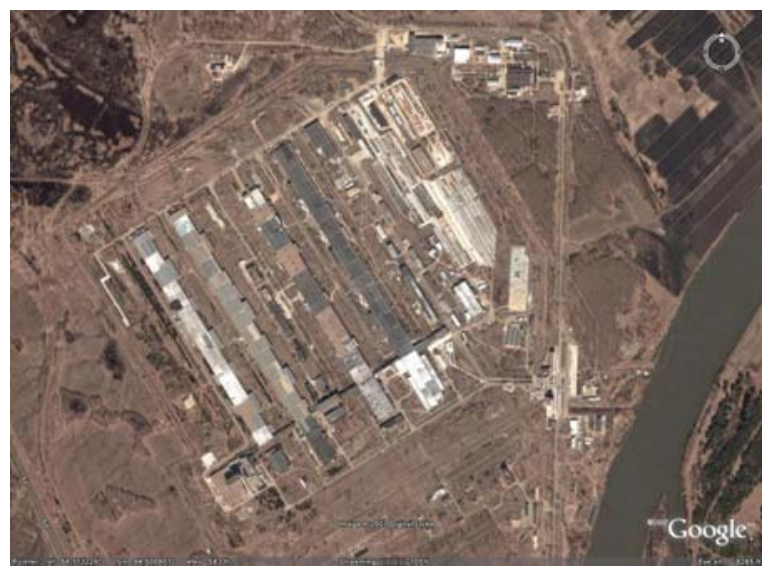

Fig. 11. Zelenogorsk, Russia.

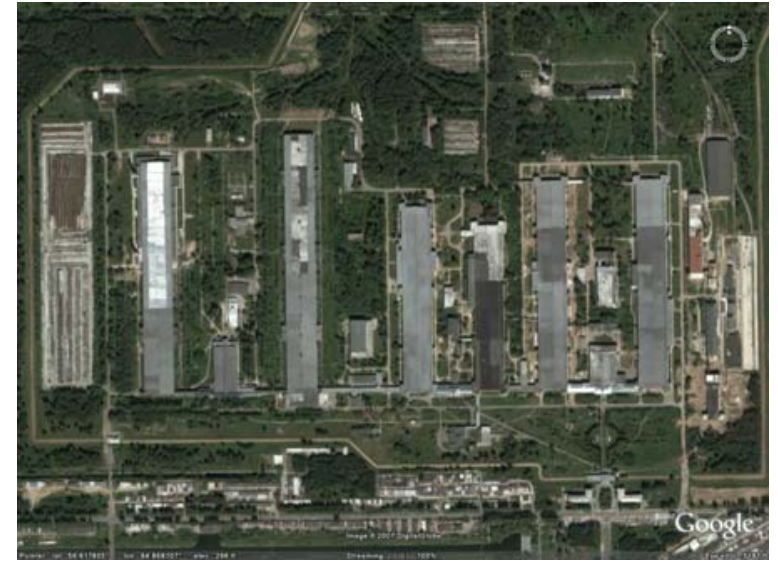

Fig. 10. Seversk, Russia.



Fig. 12. Angarsk, Russia.

Source for Figures 9-12: Google Earth

None of the Russian facilities have ever been subject to IAEA safeguards, but Russia has allowed the IAEA to conduct carefully designed and controlled ES field trials at Angarsk. On July 15, 2006, RIA Novosti reported, "Russia's nuclear chief (Sergei Kiriyenko) said the first international uranium enrichment center would be established in Angarsk, in southeast Siberia's Irkutsk Region,” and that "Russian and U.S. experts had already started combining Russia’s proposal for creating a network of 
international uranium enrichment centers, and the U.S. initiative on global partnership in the nuclear sphere. ${ }^{, 48}$ Russia added the IUEC in Angarsk to its "eligible facility list” for safeguarding as part of its voluntary offer. Currently, the level of safeguards at the center has not been determined.

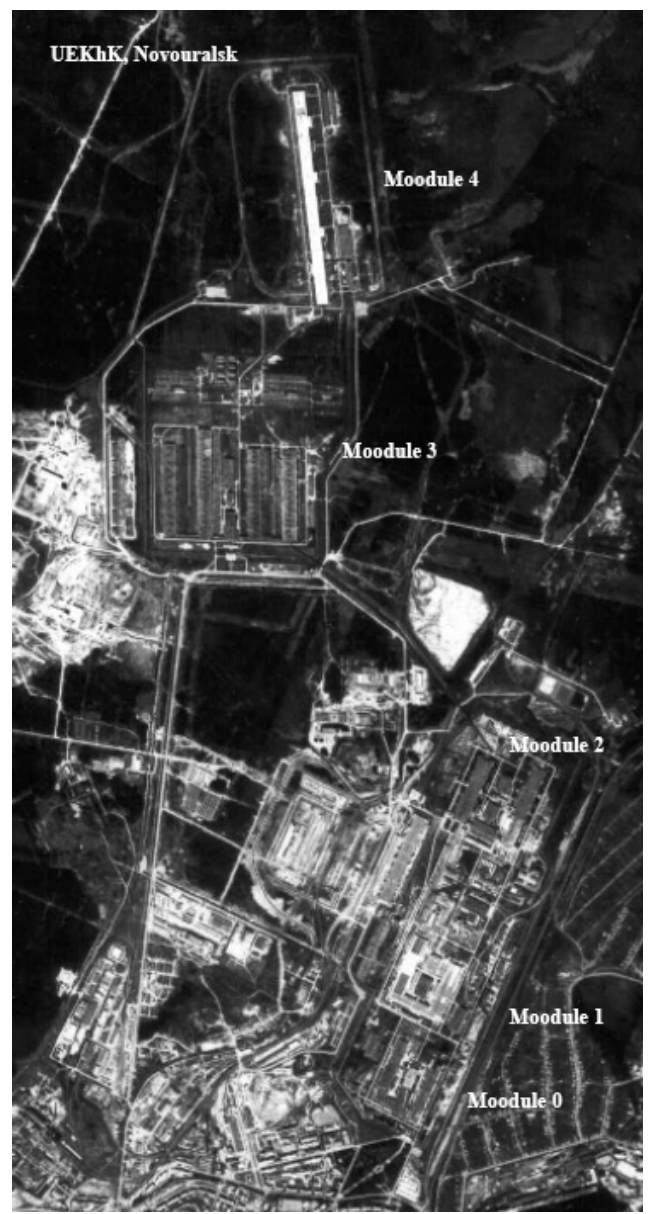

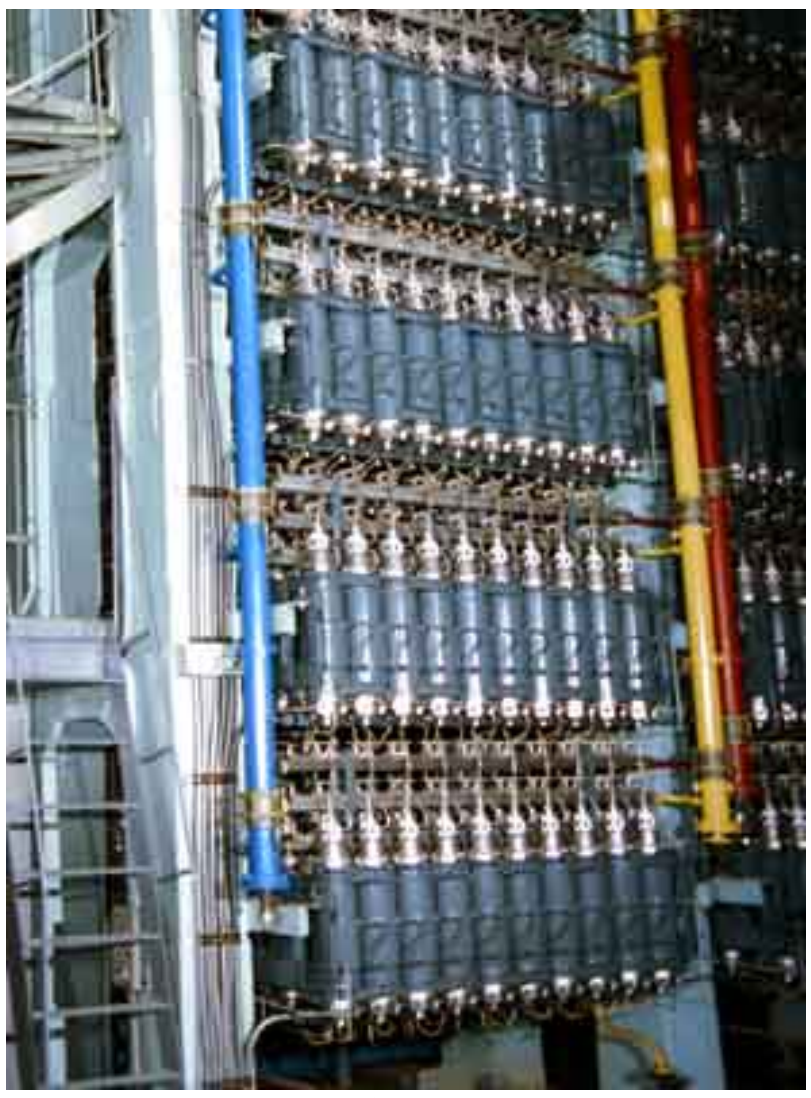

Fig. 14. Angarsk centrifuges, Russia.

Source: www.aecc.ru

Fig. 13. Novouralsk enrichment complex, Russia.

Source: Bukharin, 2004.

\subsection{FRANCE}

France constructed a GDP at Pierrelatte to produce HEU for nuclear weapons. HEU production started in 1967, and the plant's estimated capacity was around 0.5 million SWU/year. ${ }^{49}$ The lower stages of the plant were shut down in the early 1980s. In February 1996, President Jacques Chirac announced that France would permanently stop producing fissile material for nuclear weapons and would immediately shut down and dismantle the remaining stages of the Pierrelatte enrichment plant. ${ }^{50} \mathrm{HEU}$ production at Pierrelatte stopped by the middle of that year. ${ }^{51}$

The Eurodif (Georges Besse) gaseous diffusion plant in Tricastin began operation in 1979 and was completed in 1982 (Figs. 15 and 16). It consists of four process buildings, having a total capacity of 10.8 million SWU/year. ${ }^{52}$ This facility is subject to EURATOM safeguards but is not subject to IAEA safeguards. Gaseous diffusion requires a tremendous amount of electricity, so the Eurodif plant is run at its maximum capacity during off-peak periods when electricity is cheapest, and production is scaled back when electricity demand rises. Eurodif is powered by a direct connection to the four-reactor Tricastin nuclear power station and uses almost the entire station's electricity output during peak operation. ${ }^{53}$ 


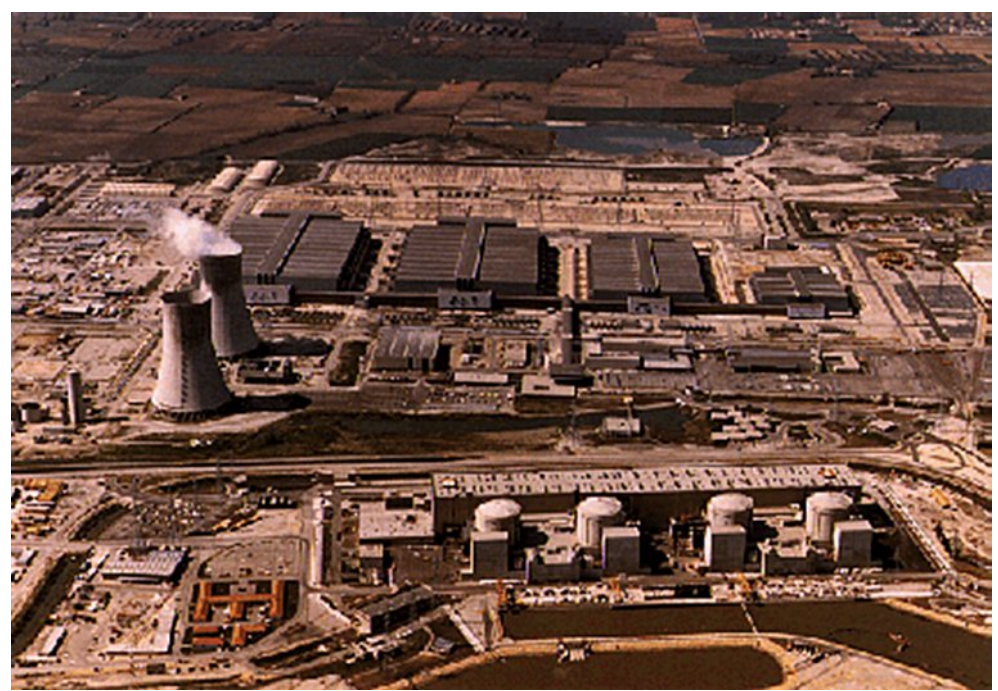

Fig. 15. Eurodif GDP, France. Source: GlobalSecurity.org



Fig. 16. Eurodif diffusion stages, France.

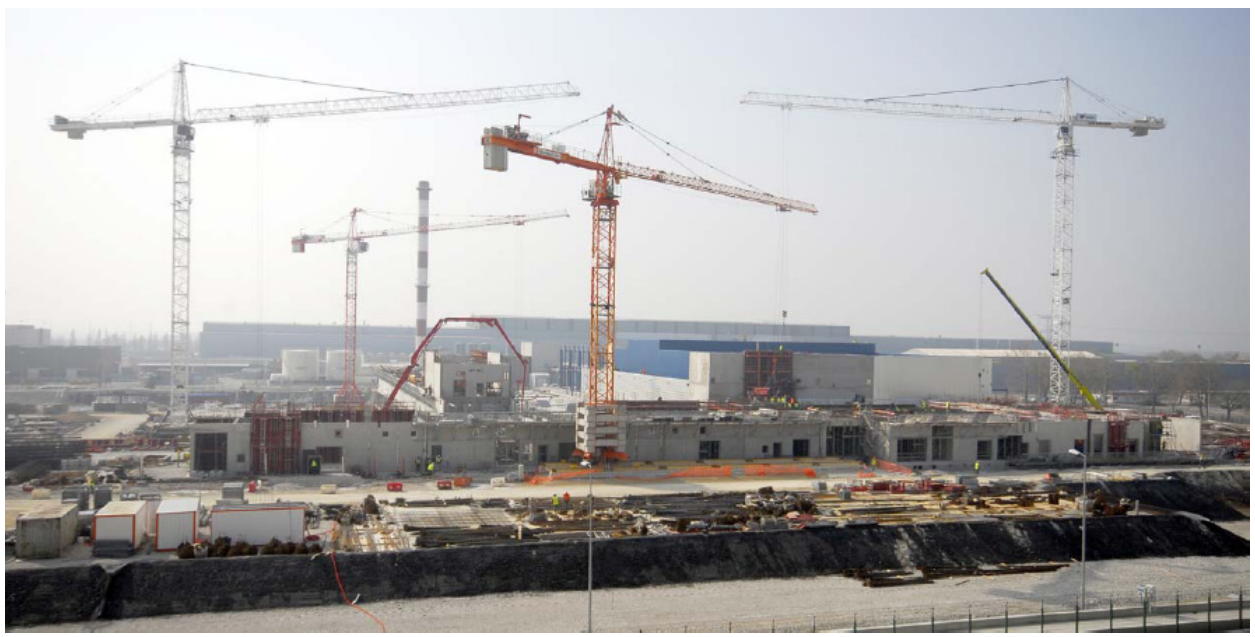

Fig. 17. Georges Besse II plant under construction, March 2007. ${ }^{54}$ 
In July 2006 Areva (parent company of Cogéma) and Urenco announced that they had finalized a "Joint Venture” under which Areva will acquire 50\% ownership of Urenco's Enrichment Technology Company (ETC). The agreement had to be approved by the European Commission, and an intergovernmental agreement had to be signed by Germany, the Netherlands, the United Kingdom, and France (the Cardiff Agreement).

ETC will design and furnish Areva with the centrifuges for a new GCEP, designated Georges Besse II, being built at Tricastin. ${ }^{55}$ Construction on the plant began in September 2006 (Fig. 17). The initial cascades are scheduled to begin operating in 2009, and the plant is expected to ramp up to a full capacity of 7.5 million SWU/year by 2016, with the option to expand up to 11 million SWU/year after that time. ${ }^{56}$ Areva announced in February 2008 that ETC has taken possession of the centrifuge assembly building at the site to begin bringing in centrifuge components and preparing to install the first cascades. ${ }^{57}$ The plant's initial license was granted in April 2007 for a maximum capacity of 8.2 million SWU/year and a maximum enrichment of $6 \%{ }^{235} \mathrm{U}^{58}$ Areva announced in June 2008 that French energy utility GDF Suez has acquired a $5 \%$ stake in the Georges Besse II plant. ${ }^{59}$

When the Georges Besse II plant comes online and the Eurodif GDP is shut down, the electricity produced by the four Tricastin reactors will be largely freed up for other uses, since centrifuge enrichment is roughly 50 times more electrically efficient than gaseous diffusion. ${ }^{60}$ However, Areva has set no firm date for shutting down the GDP after the GCEP starts production; the GDP will likely be shut down "sometime between 2010 and 2015." ${ }^{\prime \prime 1}$ Areva is said to be stockpiling LEU to make up for the shortfall after the GDP is shut down and the GCEP reaches full capacity.

\subsection{CHINA}

The Chinese gaseous diffusion plant in Lanzhou started operation in 1964 and reached a capacity of approximately 200,000 SWU/year by the late 1970s. The plant was further enlarged for commercial operation and incorporated advances in diffusion barrier technology; ${ }^{62}$ when the plant was shut down in 1997, it had a reported capacity of 500,000 SWU/year. A second gaseous diffusion plant, the Heping plant near Chengdu, is still operating and has an estimated capacity of approximately 400,000 SWU/year. ${ }^{63}$ Neither of these gaseous diffusion plants has been subject to IAEA safeguards.

China started researching gas centrifuge technology in the late 1950s. In 1993 Russia and China reached an agreement to build a gas centrifuge plant in China using Russian centrifuge technology. The initial plant was built at Hanzhong in Shaanxi province with a capacity of 200,000 SWU/year and was commissioned in June 1996. The capacity was increased to 500,000 SWU/year in 1998 with the addition of a second plant at the site. A third gas centrifuge plant with a capacity of 500,000 SWU/year, which originally was to be built with the other plants in Hanzhong, was instead built in 2001 at Lanzhou to take on the workers from the shut down Lanzhou GDP. ${ }^{64}$ In May 2008 Russia and China reached an agreement on construction of another 500,000 SWU/year GCEP, which will fulfill the fourth and final phase of the original plan and bring China's total GCEP capacity to 1.5 million SWU/year. ${ }^{65,66}$ It is not clear from the public reports whether this latest plant will be built in Lanzhou or in Hanzhong.

According to a Tripartite Agreement between China, Russia, and the IAEA, Russian-built plants in China are available for safeguarding, but only the Hanzhong GCEPs in Shaanxi have been subject to IAEA safeguards (since China is a nuclear weapons state, safeguarding additional facilities is of low priority to the IAEA due to limited resources). ${ }^{67}$ The safeguards approach for this facility was studied as part of the Tripartite Enrichment Project, which studied safeguards approaches for plants equipped with Russian centrifuge technology. Some techniques are not feasible at this facility: Russian centrifuge systems use steel piping, making CEMOs less effective; the piping arrangement in Russian-designed plants is more flexible, meaning that installed systems could be easily bypassed; and due to China's size and the location 
of the Shaanxi plant, unannounced inspections would not be effective. An approach has been adopted which includes routine inspections with material accounting, modified ES, and SWU-balancing calculations. $^{68}$

\section{OTHER HSP STATES}

Urenco was founded in 1971 by the national enrichment companies of the United Kingdom (BNFL), the Netherlands (Ultra-Centrifuge Nederland NV), and Germany (Uranit GmbH), following the signing of the Treaty of Almelo in March 1970, which was the basis for collaboration between these three states on development of centrifuge technology. The three companies formally merged under Urenco in 1993. Urenco today is an enrichment services company that operates GCEPs in the Netherlands, Germany, and the United Kingdom and is constructing a GCEP in the United States. Furthermore, Urenco has an enrichment technology group that designs and develops proprietary centrifuges for its plants, and it will also be supplying the centrifuges for the new Areva GCEP in France. It is aggressively expanding capacity at its existing enrichment plants and aims to have total capacity of 15 million SWU/year by 2012, including the new NEF GCEP in the United States but not counting any of its joint ventures with Areva. ${ }^{69,70}$ The most recent numbers for Urenco GCEP capacities cited in this report come from the Winter 2008 edition of AboutU, Urenco's quarterly corporate newsletter. ${ }^{71}$

\subsection{GERMANY}

Construction of the Gronau centrifuge plant began in April 1982, and the first cascades were started in August 1985 (Fig. 18). Initially, the facility was licensed for up to 1 million SWU/year. In October 1997 the German authorities granted a license to increase the capacity to 1.8 million SWU/year. In 1998 Urenco announced plans to build a new 2.2 million SWU/year plant (designated UTA-2) at the Gronau site and has formally applied for a license to increase the total site capacity to 4,500,000 SWU/year. ${ }^{72}$ The capacity at the Gronau site stood at 2.2 million SWU/year at the end of 2008. The earliest cascades at Gronau use block-mounted centrifuges (Fig. 19), which have multiple rotors in a single vacuum casing. Later centrifuge models are not block mounted.

All of the HSP measures have been implemented at the Gronau facility, but the IAEA had difficulty implementing the portable NDA header pipe measure, CHEM, to detect HEU because of the extremely low gas pressure, the large deposit-to-gas ratio, the small pipe diameter, and the limited measurement time in the cascade hall during an LFUA. ${ }^{73}$ The Germans have accepted environmental swipe sampling as part of the agreed upon Part 1 measures following Program 93+2; however, they are not implementing CEMO at Gronau.

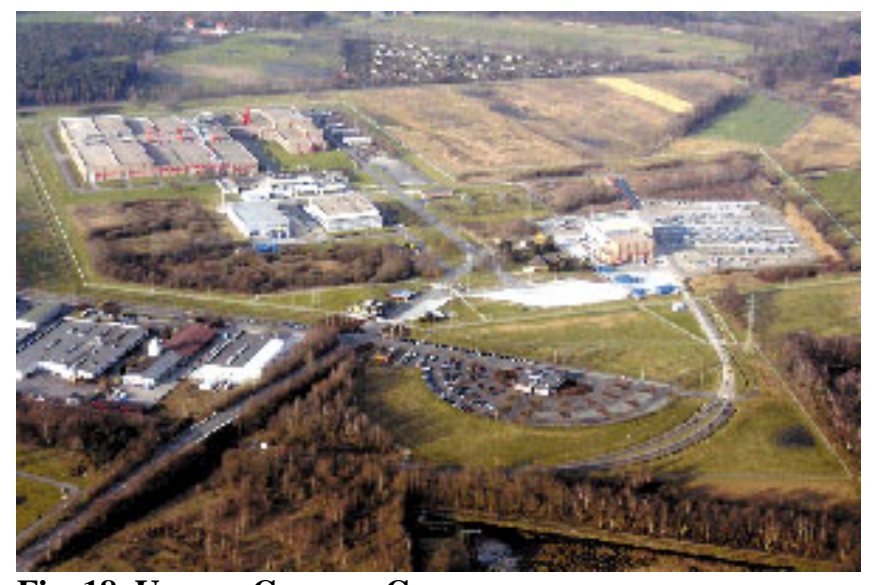

Fig. 18. Urenco Gronau, Germany.

Source: kernenergie.de

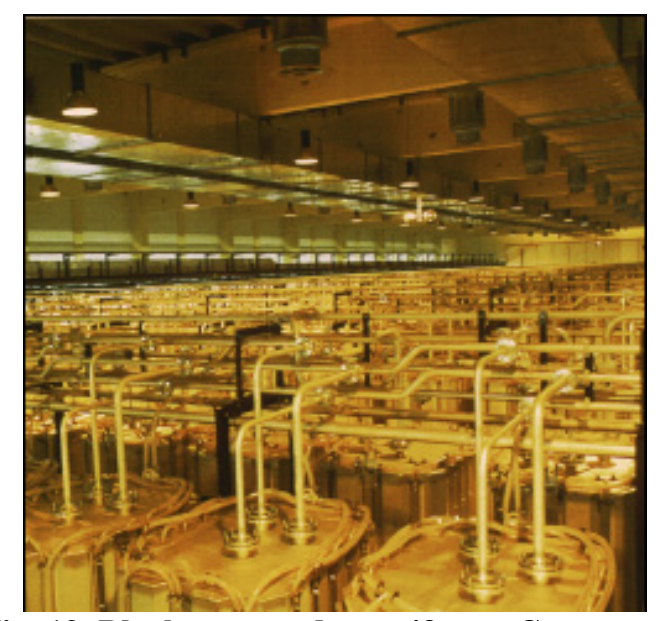

Fig. 19. Block-mounted centrifuges, Gronau. Source: U.S. DOE 


\subsection{NETHERLANDS}

Construction of the initial pilot plants at Almelo (designated SP1 and SP2) began in 1972, and the first delivery of enriched $\mathrm{UF}_{6}$ was accomplished in 1976 . These pilot plants had an approximate capacity of 25,000 SWU/year. A 200,000 SWU/year demonstration plant (SP3) was built between 1974 and 1980. These three initial plants have been decommissioned. Since 1979 construction and expansion have proceeded in two larger facilities, SP4 and SP5 (Fig. 20); the first cascades in SP5 began operating in 2000. The older plants (SP1, SP2, and SP3) have been fully decommissioned to make room for the new expansion. ${ }^{74}$ At the end of 2008, the total capacity stood at 3.8 million SWU/year, and Urenco has continued to add cascades in SP5—at the rate of approximately one cascade per month—with the goal of expanding the total capacity of Almelo to 4.5 million SWU/year by around 2012. Unlike the Urenco GCEP at Gronau, the Almelo facilities only use individually mounted centrifuges (Fig. 21).

The Netherlands was a participant in the HSP and has accepted the HSP safeguards measures in its facilities since around 1983. Following Program 93+2, the Dutch began accepting ES as part of the agreed-upon Part 1 measures. Reportedly, there is no on-line enrichment monitoring at Almelo, but the Dutch allow LFUA walkthroughs. ${ }^{75}$

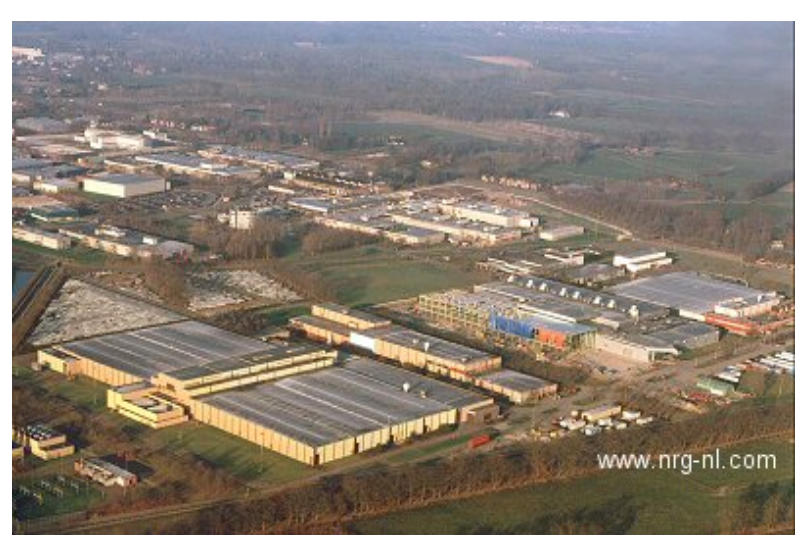

Fig. 20. Urenco Almelo, Netherlands. Source: nrg-nl.com

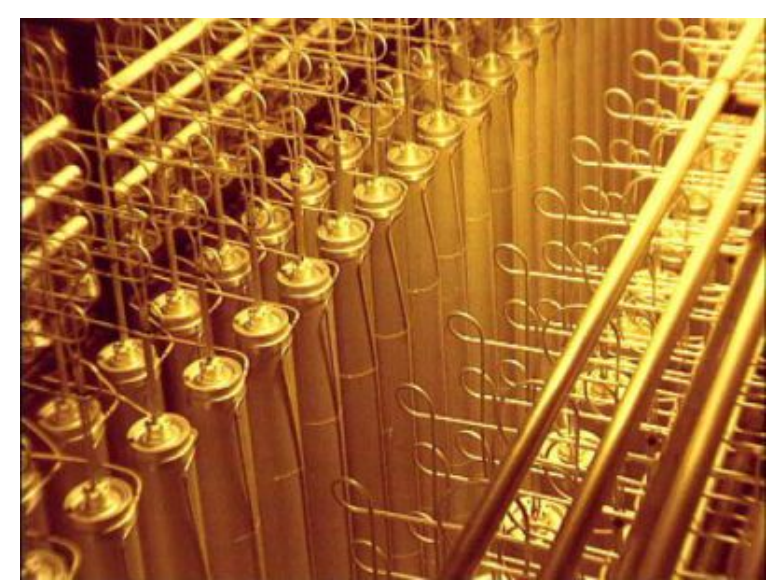

Fig. 21. Urenco centrifuges, Almelo. Source: world-nuclear.org

\subsection{JAPAN}

The Power Reactor and Nuclear Fuel Development Corporation of Japan (PNC) began operating pilot gas centrifuge facilities at Ningyo-Toge in 1979. PNC became the Japan Nuclear Cycle Development Institute (JNC) in 1998 and was merged into the Japan Atomic Energy Agency (JAEA) in 2005. The Ningyo-Toge pilot facility had a nominal capacity of 50,000 SWU/year and was shut down in 1990. Two 100,000 SWU/year demonstration plants began operating at the site in June 1988 and ceased operation in March $2001 .^{76}$ These facilities are being dismantled centrifuge by centrifuge, with individual components decontaminated to reduce radioactive waste volume and destroyed to protect sensitive design information. ${ }^{77}$ In addition, various laboratory-scale enrichment facilities involving gas centrifuge, AVLIS, and MLIS technology have been operated, shut down, and dismantled, mostly at Tokai. ${ }^{78}$ 


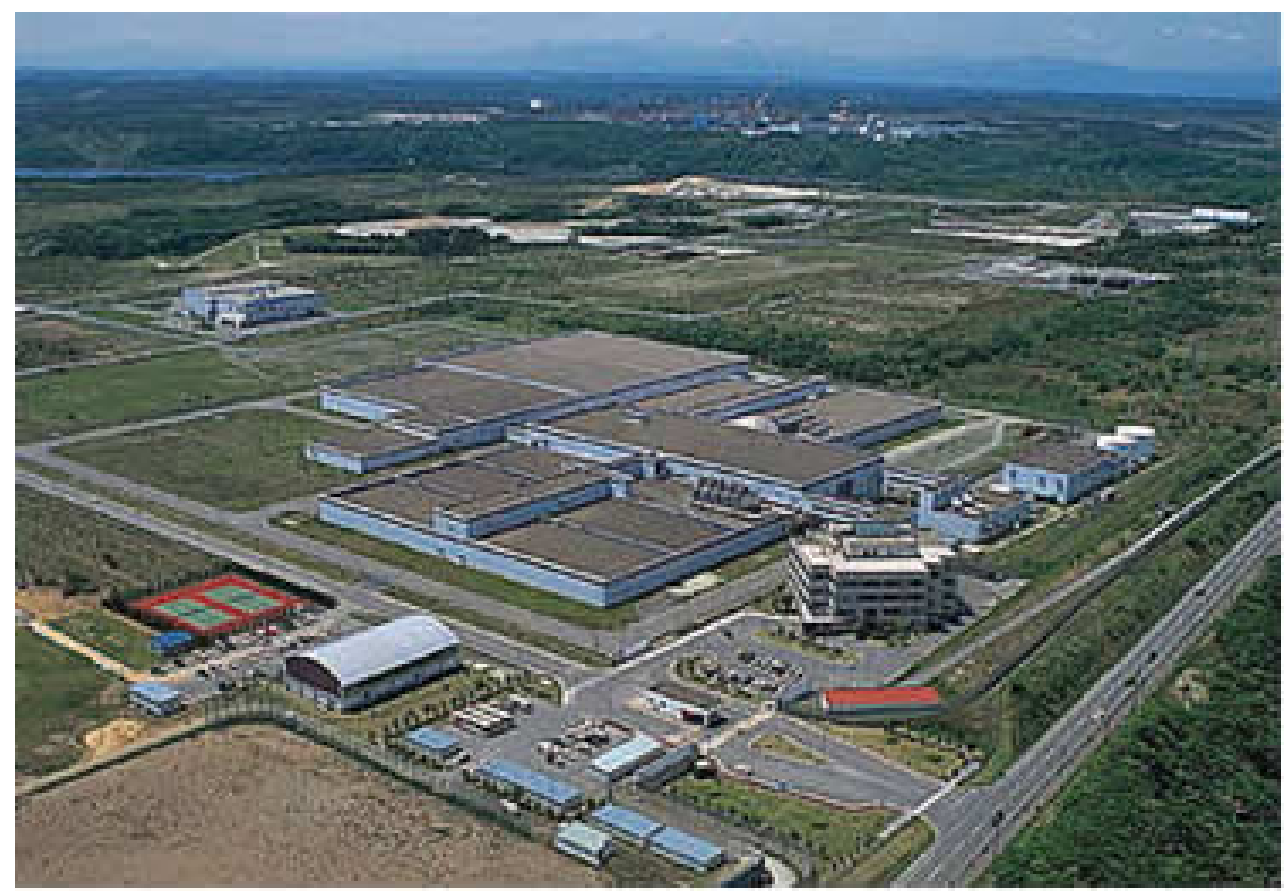

Fig. 22. Rokkasho Uranium Enrichment Plant, Japan. Source: japannuclear.com

The gas centrifuge facility in Rokkasho-mura, the Rokkasho Uranium Enrichment Plant (Fig. 22), was built by Japan Nuclear Fuel Limited (JNFL). Construction began in October 1988, and the initial unit began operation in 1992 with a capacity of 150,000 SWU/year. Six additional units have come online to increase the total capacity to 1,050,000 SWU/year. Currently, only one of the modules is operating $\left(150,000 \mathrm{SWU} /\right.$ year) due to problems with the centrifuges, ${ }^{79}$ which are not being repaired since they are scheduled to be replaced. The production capacity is targeted to increase to 1,500,000 SWU/year using advanced centrifuges with carbon fiber-composite rotors. ${ }^{80}$ In April 2007 JNFL announced the start of cascade tests of its advanced centrifuge design. ${ }^{81}$ Cascade tests using $\mathrm{UF}_{6}$ began in November 2007. Production using the advance centrifuges is slated to begin in 2010, with full capacity and complete replacement of the older-model centrifuges to be reached within 10 years. ${ }^{82,83}$

In March 2009 Russia signed an agreement with the Japanese company Toshiba to explore the possibility of constructing new GCEPs in Japan based on Russian centrifuge technology. ${ }^{84}$ No details have so far been released on number, size, or location of any plants that could be constructed under this agreement.

The Japanese were participants in the HSP and have implemented all of the HSP measures, as well as additional measures such as ES inside the cascade halls, at their demonstration and commercial facilities. ${ }^{85}$

\subsection{AUSTRALIA}

The Australian Atomic Energy Commission (AAEC), the predecessor to the Australian Nuclear Science and Technology Organisation (ANSTO) had a gas centrifuge research and development program in the 1970s and 1980s and was a participant in the HSP. Bench-top cascade operation was achieved at the Lucas Heights Science and Technology Centre (Fig. 23), but the program was terminated in 1983 with no pilot plant built. ${ }^{86}$ When the centrifuge program was terminated, Australia decided to deny the IAEA access to the dismantled centrifuge components on the basis of protecting proprietary technology. All blueprints, scientific reports, and components relating to the centrifuge program remain securely stored at Lucas Heights. As part of the 93+2 program, the IAEA was allowed limited access to the components for 
verification purposes. In addition, the buildings that housed the centrifuge program were used as an early testbed for IAEA environmental sampling techniques:

The buildings had been cleaned out, decontaminated and repeatedly repainted in the 10 year period before sampling took place. While these activities had been part of a normal pattern of building reassignment and usage in the case of Australia's declared program, the activities were similar in nature to the steps a proliferator might use to conceal the existence of a clandestine program. IAEA ES had no difficulty in determining the location within the building of the various aspects of centrifuge work. The IAEA was also able to determine the average enrichment level that was achieved during the research project and the maximum level of enrichment achieved. ${ }^{87}$

However, the technology and expertise for centrifuge enrichment are still present, and the Australian government is said to be considering re-launching a uranium enrichment program in the country for the purpose of "value-adding" to its current uranium exports, but no actions have been taken at this point. ${ }^{88}$

Australia is also developing a laser isotope separation process called SILEX (separation of isotopes by laser excitation), a variation of MLIS, at Lucas Heights. Silex Systems Limited and GE-Hitachi are constructing a "Test Loop" of the SILEX laser enrichment process in Wilmington, North Carolina. In August 2007 Silex Systems announced "the successful completion of the transfer of our uranium enrichment project from our Lucas Heights facility to GE's Nuclear Fuel Plant in Wilmington North Carolina." ${ }^{89}$ The application of this technology in the United States is discussed in Sect. 2.1.

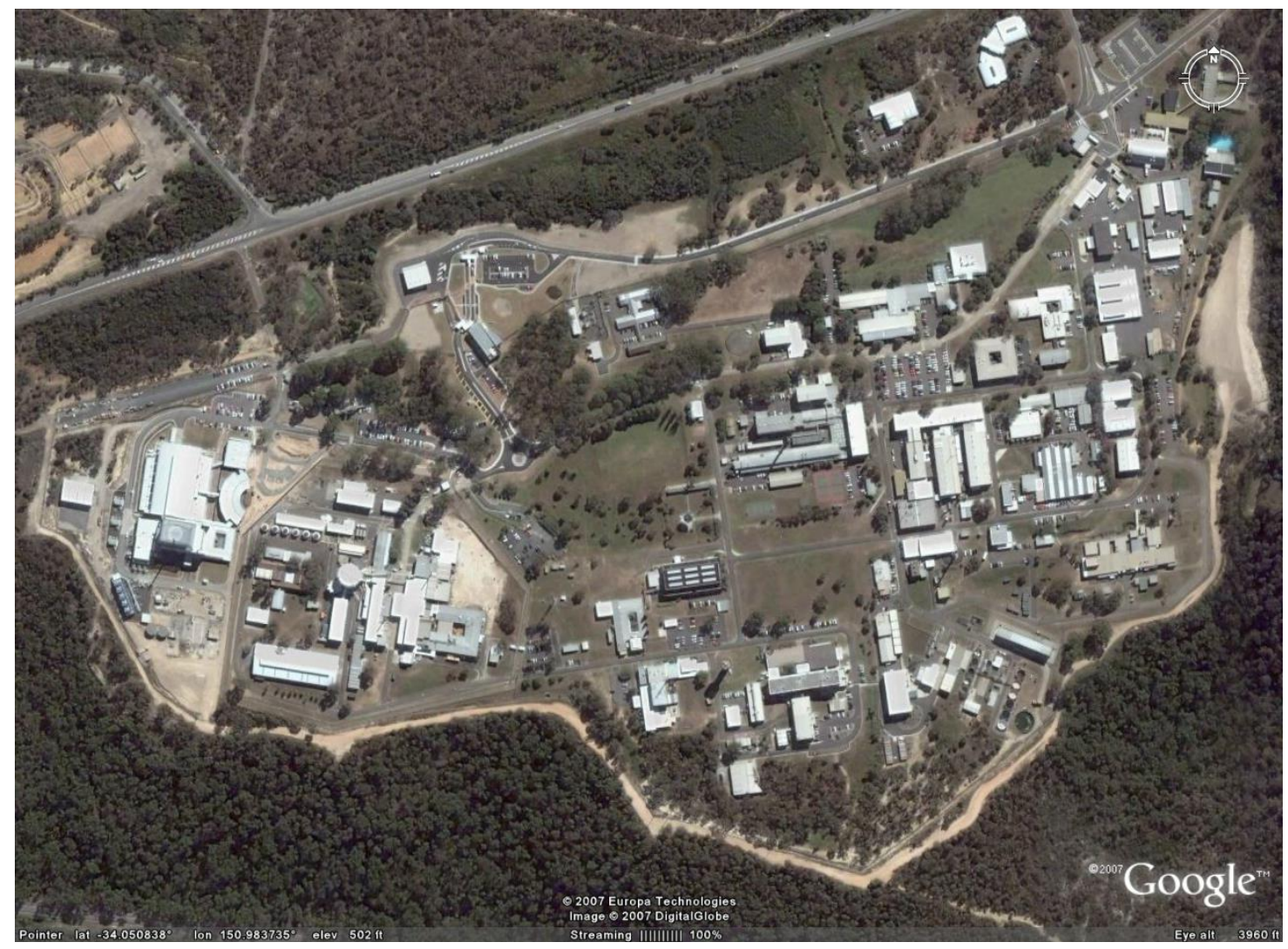

Fig. 23. Lucas Heights Science and Technology Centre, Australia. Source: Google Earth 


\section{OTHER NPT STATES}

Several other states have enrichment facilities, although none are currently large enough to produce surplus LEU for export. South Africa and Argentina have enrichment facilities that are shut down, although Argentina has announced plans to resume enrichment activities at its plant. Brazil and Iran are both constructing moderate-size GCEPs reportedly intended to provide LEU for their own power reactors, and both plants are safeguarded by the IAEA.

Brazil and Argentina formed the bilateral Brazilian-Argentine Agency for Accounting and Control of Nuclear Materials (ABACC) in 1991 as "an entity responsible for verifying that the nuclear materials existing in both countries are being used for exclusively peaceful purposes." ${ }^{\circ 0}$ ABACC inspectors implement safeguards measures at the nuclear facilities in both states; Brazil and Argentina also signed a Quadripartite Agreement with ABACC and the IAEA in 1991 to coordinate safeguards activities and avoid duplicate inspections by the two agencies. ABACC is responsible for coordinating the analysis of environmental samples at laboratories in Brazil and Argentina ${ }^{91,92}$ and is working to optimize HSP safeguards techniques for the lower-capacity centrifuge enrichment facilities under its jurisdiction. ${ }^{93}$ In February 2008 the presidents of Argentina and Brazil discussed a bilateral project to pursue a joint uranium enrichment venture. ${ }^{94}$ While the project is still very preliminary and no official agreement has been reached, the initial plan would be for Argentina to produce slightly enriched uranium at its GDP for use in its reactors and as feedstock for the Brazilian GCEP. ${ }^{95}$

States have also done laboratory-scale experiments in uranium enrichment. For example, in 2004 the Republic of Korea disclosed as part of its Additional Protocol declaration that in 2000 government scientists had performed unauthorized enrichment of uranium during a larger project of enriching stable isotopes with an AVLIS process. ${ }^{96}$ The laboratory-scale experiments produced about 200 milligrams of uranium enriched up to $77 \%{ }^{235} \mathrm{U}^{97}$ These experiments in uranium enrichment did not include the planning or building of production facilities.

\subsection{BRAZIL}

Brazil has two operating pilot gas centrifuge facilities at the Aramar Experimental Center, located about 100 kilometers west of Sao Paulo (Fig. 24). The total capacity of these two plants is reported to be about 9,000 SWU/year. ${ }^{98}$ A commercial enrichment facility is under construction at a site near Resende (Fig. 25), located about 100 kilometers from Rio de Janeiro. The Resende site also contains a fuelfabrication facility and a $\mathrm{UF}_{6}$-to- $\mathrm{UO}_{2}$ uranium conversion plant. The enrichment plant is being constructed by state-owned Indústrias Nucleares do Brasil (INB), which signed a contract with the Brazilian navy in 2000 to use navy-designed centrifuges. ${ }^{99} \mathrm{UF}_{6}$ was introduced into the first cascade in early 2005. The first module, which will eventually contain four cascades, was officially inaugurated by the Ministry of Science and Technology in May 2006. ${ }^{100}$

The Brazilian nuclear energy commission (the Comissão Nacional de Energia Nuclear, CNEN) gave the Resende GCEP initial operating authorization (good for one year) in January 2009, and the plant is expected to begin industrial operation with the two completed cascades of the first module early in 2009 and produce up to 12 tons of LEU by the end of the year. ${ }^{101,102}$ The plant is expected to have ten cascades operating by 2012 and reach full capacity (four modules of four cascades each, for a total of approximately 120,000 SWU/year) by 2015. By 2012 the GCEP is expected to be producing enough LEU to provide all the fuel for Angra I and 20\% of the fuel for Angra II, Brazil's existing power reactors. Providing all the LEU for both reactors would require enrichment capacity of approximately 250,000 SWU/year. ${ }^{103}$ 


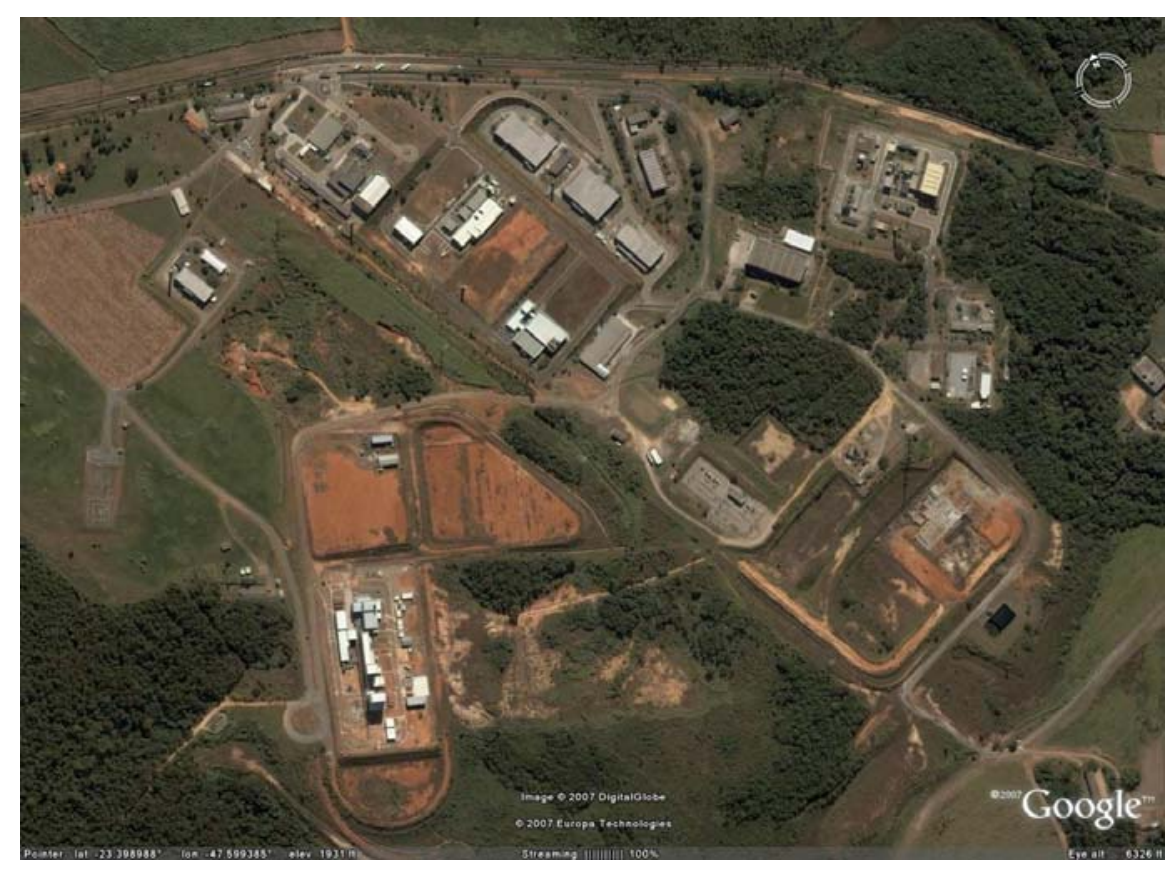

Fig. 24. Aramar Experimental Center, Brazil. Source: Google Earth

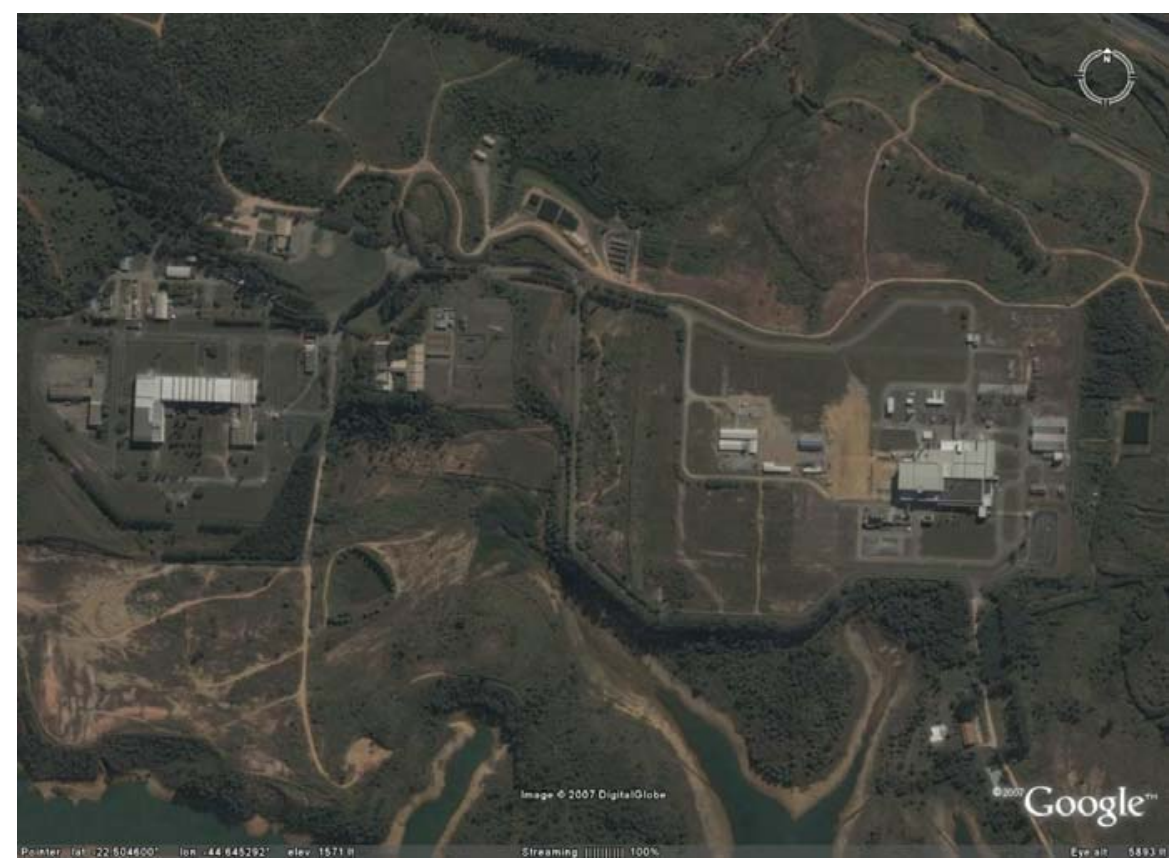

Fig. 25. Resende Nuclear Fuel Facility, Brazil. Source: Google Earth

The specific safeguards approach for the Resende plant was under negotiation for a number of years. Brazil is concerned with restricting access to proprietary information about its centrifuge design, which reportedly has two proprietary active magnetic bearings, top and bottom, instead of the usual one as in other commercial centrifuge designs. ${ }^{104}$ Differences centered on whether IAEA inspectors would be allowed full visual access within the cascade hall or whether Brazil would be allowed to keep the equipment shrouded. Brazil and the IAEA finally reached agreement on the safeguards approach in the fall of 2004. ${ }^{105}$ Under the agreed-upon approach, IAEA inspectors are not permitted to remove visual information about the cascades at Resende and Aramar. The inspectors are allowed to have limited visual 
access to the cascades and compare what they see to a validated set of baseline photographs held by the operator under IAEA seal. The compromise, which also allowed Brazil to shroud access to the bearings in the first module, applies only to this first stage of operation at Resende. The agreement will be renegotiated and the casings redesigned for safeguarding the full-capacity plant.

At Aramar, ES is permitted only for cylinders and the feed and withdrawal (F/W) stations. At Resende, ES is also allowed inside the cascade hall. All inspections are essentially unannounced inspections with full access to F/W stations and the results of destructive assay measurements. NDA inside the cascade halls is not considered in the approach at Resende; however, the IAEA has been permitted to take supplemental NDA measurements at Aramar to compensate for the lack of complete visual access.

The Brazilian president has announced funding to complete construction of the Angra III reactor and emphasized that one of the aims of the country's nuclear program is to design, build, and fuel a nuclear submarine. ${ }^{106}$ The government has reportedly earmarked nearly $\$ 25$ billion for these nuclear projects, including uranium enrichment, through 2010. INB reportedly plans to expand the Resende GCEP to supply LEU fuel for all future Brazilian reactors as they come online. ${ }^{107}$

Brazil has not signed an Additional Protocol with the IAEA, and is thought to be reluctant to do so in order to protect its nuclear submarine program, which could be subject to IAEA scrutiny under the Additional Protocol. ${ }^{108}$

\subsection{ARGENTINA}

In the late 1970s through early 1980s, when Argentina was under military rule and before it acceded to the NPT, it began a secret program to develop indigenous gaseous diffusion technology. The existence of this technology and the gaseous diffusion enrichment plant built at Pilcaniyeu (Figs. 26 and 27) in the Rio Negro province were successfully concealed until the government of President Raúl Alfonsin revealed them, shortly after the restoration of civilian rule.

Plant operation at Pilcaniyeu was suspended in the late 1980s with the intention to restart it after some upgrades were completed. With the signing of the Quadripartite Agreement in 1994, the facility became subject to full scope safeguards. Although not operating, the IAEA still had to verify the material inventory. Since this was the first gaseous diffusion plant subjected to IAEA safeguards, the Agency needed a method to verify the in-process cascade inventory. Cascade inventory verification had not been a significant concern for centrifuge plants because the process inventory of a GCEP is on the order of a thousand times smaller than that for a GDP. After the inventory was verified with assistance from the U.S. Support Program, the IAEA continues to verify that the status of the plant is unchanged and the plant has not operated.

Reportedly, the initial planned capacity was 20,000 SWU/year with longer-term plans to expand to 100,000 SWU/year. A portion of the cascade was completed in the mid-1980s, but the plant has never operated well due to problems with short barrier life, leaking seals, and compressor reliability. The cascade consists of 20 units with 20 stages each (400 stages total). During its operation, Argentina produced only small amounts of LEU. In 1989 the cascade was shut down, and a new 20-stage pilot plant with improved technology was opened in December 1993. Renovation of the older plant, to be operated under safeguards, was subsequently undertaken, but progress was slow and was plagued with long periods of inactivity. 




Fig. 26. Pilcaniyeu, Argentina. Source: Google Earth

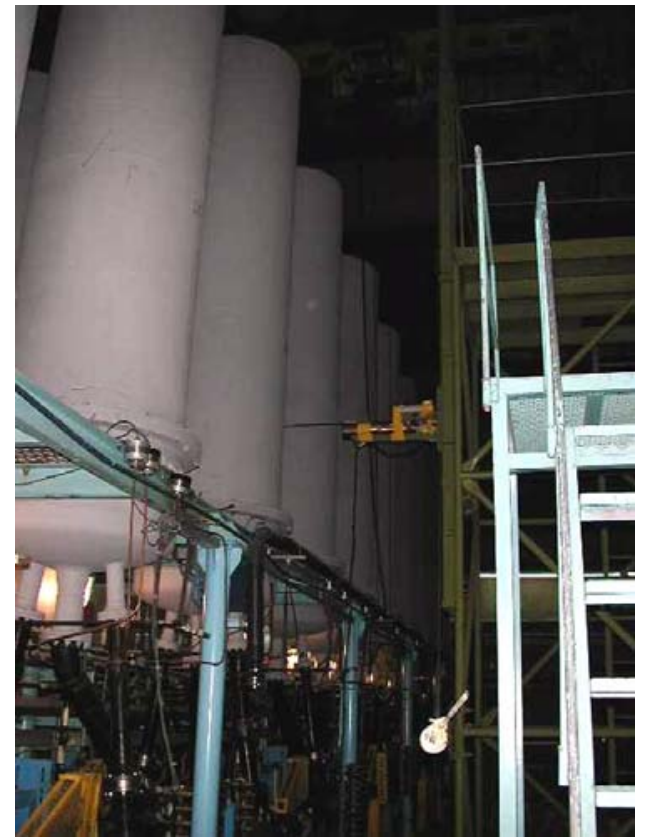

Fig. 27. Argentine diffusers, Pilcaniyeu. Source: Whitaker, $2005^{109}$

In August 2006 Planning Minister Julio De Vido announced that Argentina is going to expand its nuclear program, including completion of the Atucha 2 and CAREM reactors and reactivation of its uranium enrichment capability at Pilcaniyeu. ${ }^{110}$ Argentina currently has two operating nuclear reactors: a CANDU at Embalse and a German-designed pressurized heavy water reactor designated Atucha 1. The completion of Atucha 2 and the reactivation of Pilcaniyeu are both expected sometime in the next two years. ${ }^{111}$ It has been reported that one of the reasons for resuming enrichment is to establish Argentina's place as an enrichment supplier country. Canada announced in July 2007 that it had reached a preliminary agreement with Argentina on supplying a new CANDU-6 reactor beyond Atucha 2, which would be built at Embalse. ${ }^{112}$ 


\subsection{SOUTH AFRICA}

South Africa constructed and operated two enrichment plants at Pelindaba (Fig. 28): one to produce HEU for a weapons program ("Y-Plant”) and a second semi-commercial plant to produce LEU ("Z-Plant”). Both plants used a unique aerodynamic enrichment method called the Helikon vortex separation process. The Helikon process requires large amounts of electricity and produces a lot of waste heat, making it uneconomical as a commercial enrichment process. Using HEU from Y-Plant, South Africa assembled six gun-type nuclear weapons, and a seventh was being constructed when the country revealed the program and began to dismantle its weapons program. ${ }^{113}$ The HEU plant was shut down prior to South Africa acceding to the NPT in 1991, and the IAEA applied safeguards to the semi-commercial plant until it was shut down in $1995 .{ }^{114}$ In 1994 the IAEA confirmed that South Africa's nuclear weapons program had been completely terminated and dismantled. ${ }^{115}$

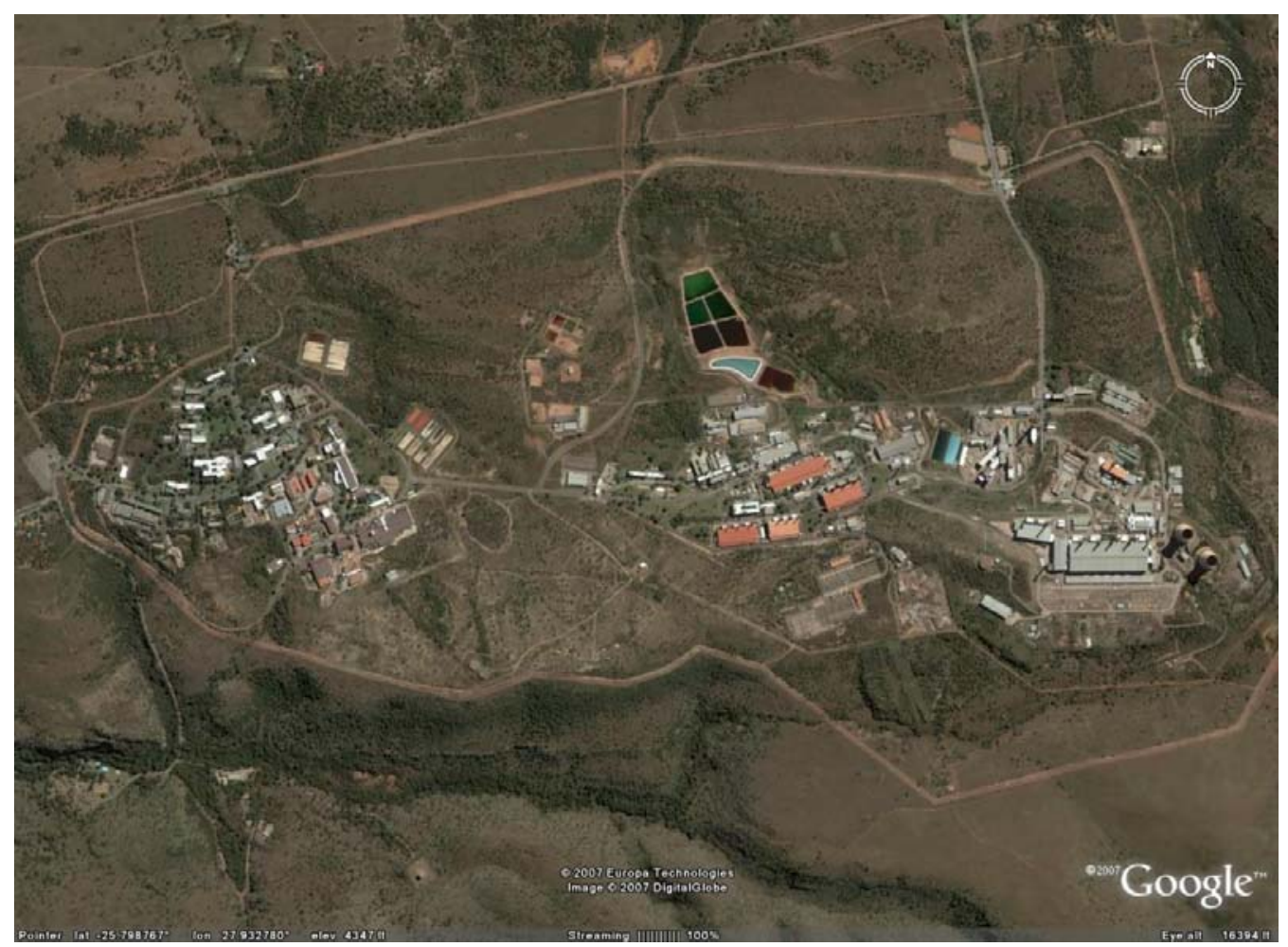

Fig. 28. Pelindaba, South Africa. Source: Google Earth

In August 2006 the Minister of Minerals and Energy said that South Africa would conduct a cost-benefit study on reviving the country's enrichment program (uranium "beneficiation”) as part of a larger effort to expand its nuclear power industry. ${ }^{116}$ A draft of South Africa's nuclear energy policy, released for public comment in July 2007, states that the "government's strategic intent is to develop national capacity in uranium enrichment as part of uranium beneficiation. Government, through the Nuclear Energy Corporation of South Africa (NECSA), shall investigate the viability of developing its own uranium enrichment capabilities and will simultaneously actively seek to acquire established uranium enrichment technologies to ensure security of supply."117

A South African company called Klydon has been working since 1997 to modernize the Helikon enrichment process to make it commercially competitive. The company has built a pilot plant for stable isotope enrichment but has so far not enriched uranium. Once they are able to make the process efficient enough to be commercially competitive, the company plans to begin re-enriching DU tails and producing slightly enriched uranium to sell to other enrichers as feedstock. ${ }^{118,119}$ 


\subsection{IRAQ}

Iraq began investigating clandestine uranium enrichment for a nuclear weapons program after the bombing of the Osirak reactor by Israel in 1981 conveyed the need to pursue parallel fissile material programs (plutonium production and uranium enrichment). Iraqi scientists chose to primarily pursue EMIS technology in the near term, with gaseous diffusion as a backup and to produce LEU feedstock for the EMIS program, and gas centrifuge enrichment as a longer-term goal. Some preliminary research also took place on laser enrichment. Construction began on the first EMIS facility in 1987. Progress on both EMIS and diffusion was slow, and in 1988 officials decided to de-emphasize diffusion and concentrate more on centrifuges. According to David Albright of the Institute for Science and International Security (ISIS), who conducted interviews with Iraqis and Germans involved with the program, Iraq received illicit assistance from German centrifuge experts. ${ }^{120}$ They also pursued chemical enrichment as another LEU feedstock provider for EMIS. The 1990-1991 Gulf War and especially the bombing campaign against Iraq in January 1991 brought the program to a halt. At this point, the Iraqi enrichment program had only succeeded in producing a few grams of uranium enriched to slightly over $20 \%{ }^{235} \mathrm{U}$. IAEA inspections of Iraq's nuclear facilities began in the summer of 1991, after the war ended (Figs. 29 and 30). ${ }^{121}$ Inspections continued until inspectors were withdrawn in December 1998 amid continuing international suspicion that Iraq was continuing parts of its nuclear program; IAEA inspections resumed in November $2002 .{ }^{122}$ After the March 2003 invasion of Iraq by the United States, U.S. inspectors attempted to secure all known Iraqi nuclear materials and facilities. ${ }^{123}$



Fig. 29. Calutron wreckage in Iraq in the 1990s. Source: fas.org 


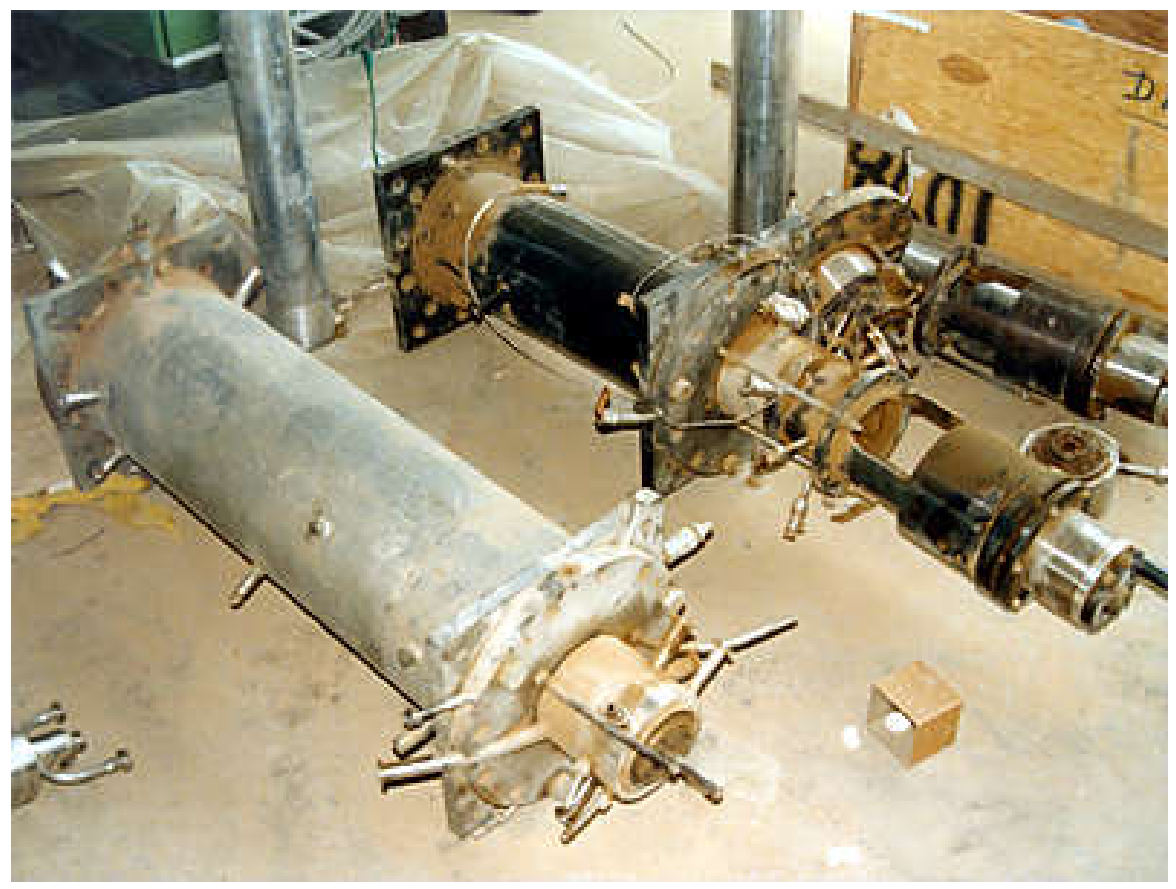

Fig. 30. Centrifuges discovered in Iraq by IAEA inspectors in the 1990s. Source: iaea.org

\subsection{LIBYA}

In December 2003 Libya publicly revealed and renounced its nuclear weapons program. IAEA inspection teams were in Libya by the end of the month, and IAEA and foreign experts worked with Libya to thoroughly verify its declaration and secure the nuclear material and equipment. In March 2004 Libya signed an Additional Protocol with the IAEA. ${ }^{124}$

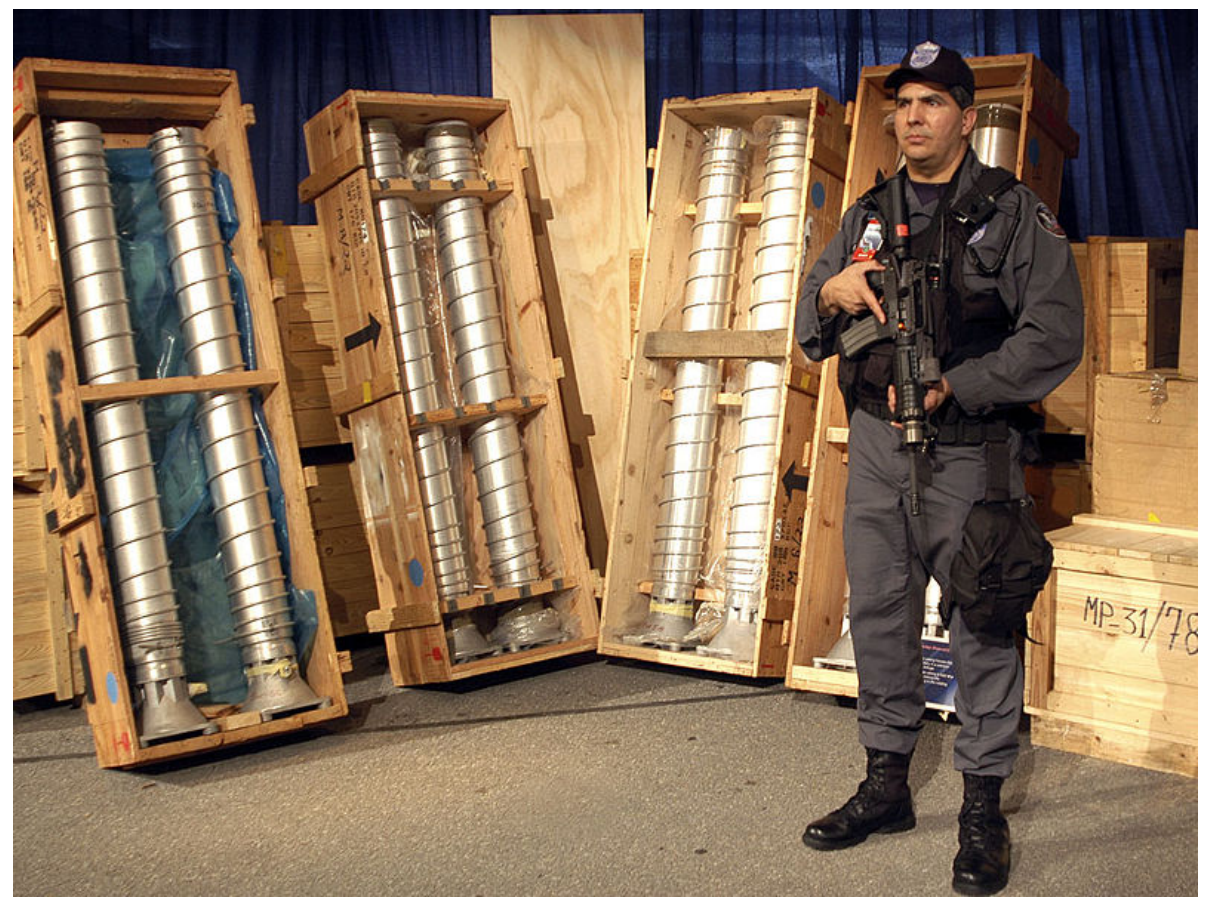

Fig. 31. Libyan centrifuge casings. 
Libya based its enrichment program on equipment and information obtained through the A. Q. Khan network. The IAEA reports that in the late 1990s and early 2000s, Libya obtained 20 complete L-1 (or P-1) centrifuges and 2 complete L-2 (or P-2) centrifuges through the network, as well as at least some of the parts necessary for 200 additional L-1 and 10,000 additional L-2 centrifuges, largely produced at a factory in Malaysia under the direction of A. Q. Khan associates. ${ }^{125}$ By 2002 several small test cascades had been partially constructed but never operated, and these were all dismantled and put into storage by the time of Libya's declaration. ${ }^{126}$ Much of Libya's centrifuge equipment and nuclear material, including four cylinders of $\mathrm{UF}_{6}$, was transported in January 2004 to the Y-12 National Security Complex in Oak Ridge, Tennessee, for storage (Fig. 31). ${ }^{127,128}$

\subsection{IRAN}

It was revealed to the public in 2002 that Iran was constructing a centrifuge plant for uranium enrichment at Natanz, south of Tehran, as well as a heavy water production plant at Arak. ${ }^{129}$ The Natanz facility (Figs. 32 and 33) includes a small Pilot Fuel Enrichment Plant (PFEP) with two 164-centrifuge cascades and several smaller test cascades of various centrifuge models, and a full-scale underground Fuel Enrichment Plant (FEP) designed for approximately 50,000 centrifuges and an estimated total capacity of 250,000 SWU/year. ${ }^{130}$ The facility is overseen by the Atomic Energy Organization of Iran (AEOI). The designs for the centrifuges at Natanz as well as many centrifuges and centrifuge components were supplied to Iran by the A. Q. Khan network.

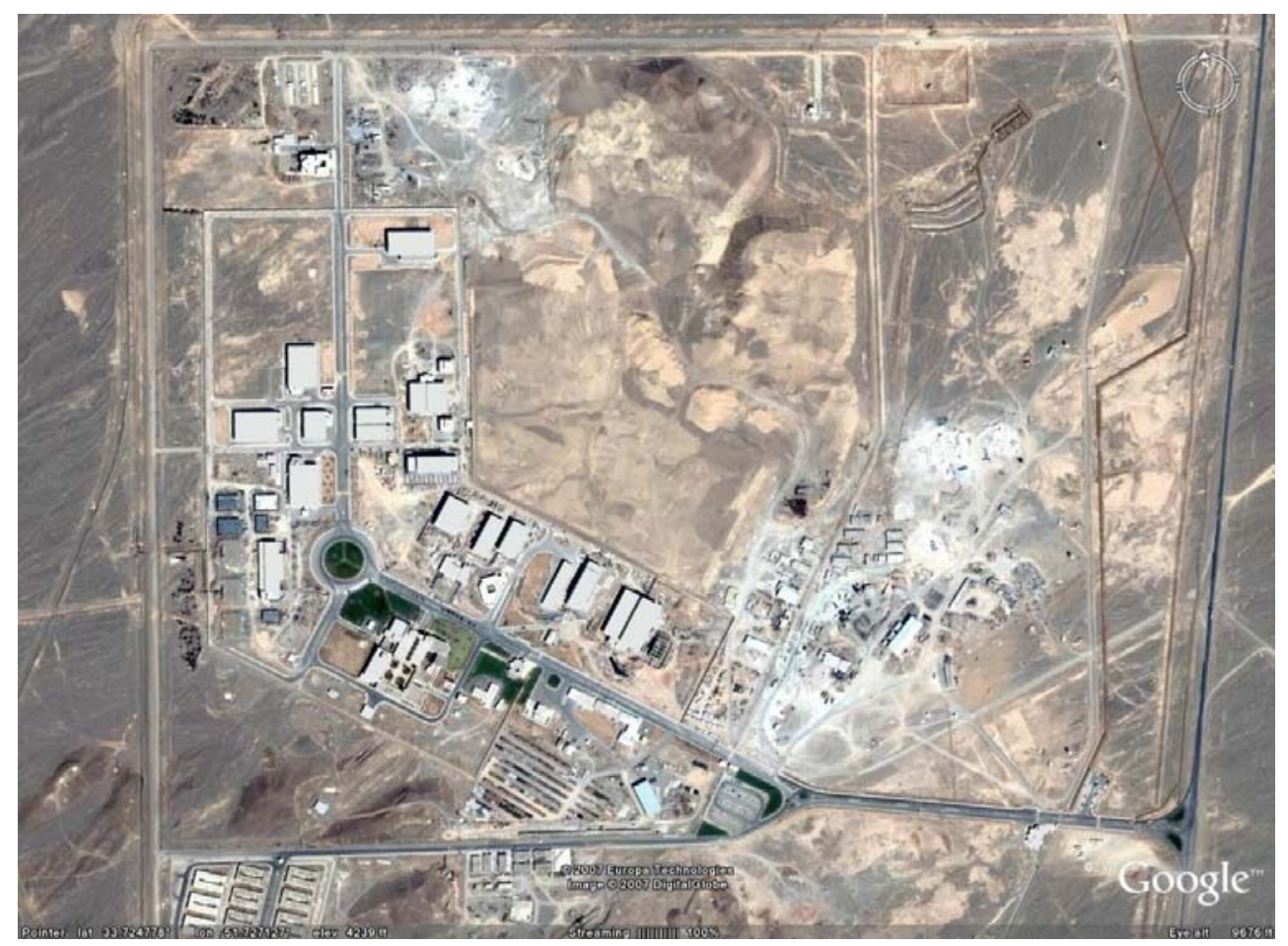

Fig. 32. Natanz, Iran. Source: Google Earth

Iran has been enriching small amounts of uranium at the PFEP since April 2006. Construction and installation of centrifuge cascades are continuing at the FEP, and Iran has been enriching uranium there since February 2007. As of the August 2007 Director General's report to the IAEA Board of Governors, Iran was enriching uranium in twelve 164-centrifuge cascades at the FEP, operating one cascade without $\mathrm{UF}_{6}$, vacuum-testing one, and installing two more. At that time, Iran had fed approximately 690 kilograms of natural $\mathrm{UF}_{6}$ into the cascades, and ES by the IAEA had verified the production of uranium enriched up to $3.7 \%{ }^{235} \mathrm{U}^{131,132}$ 


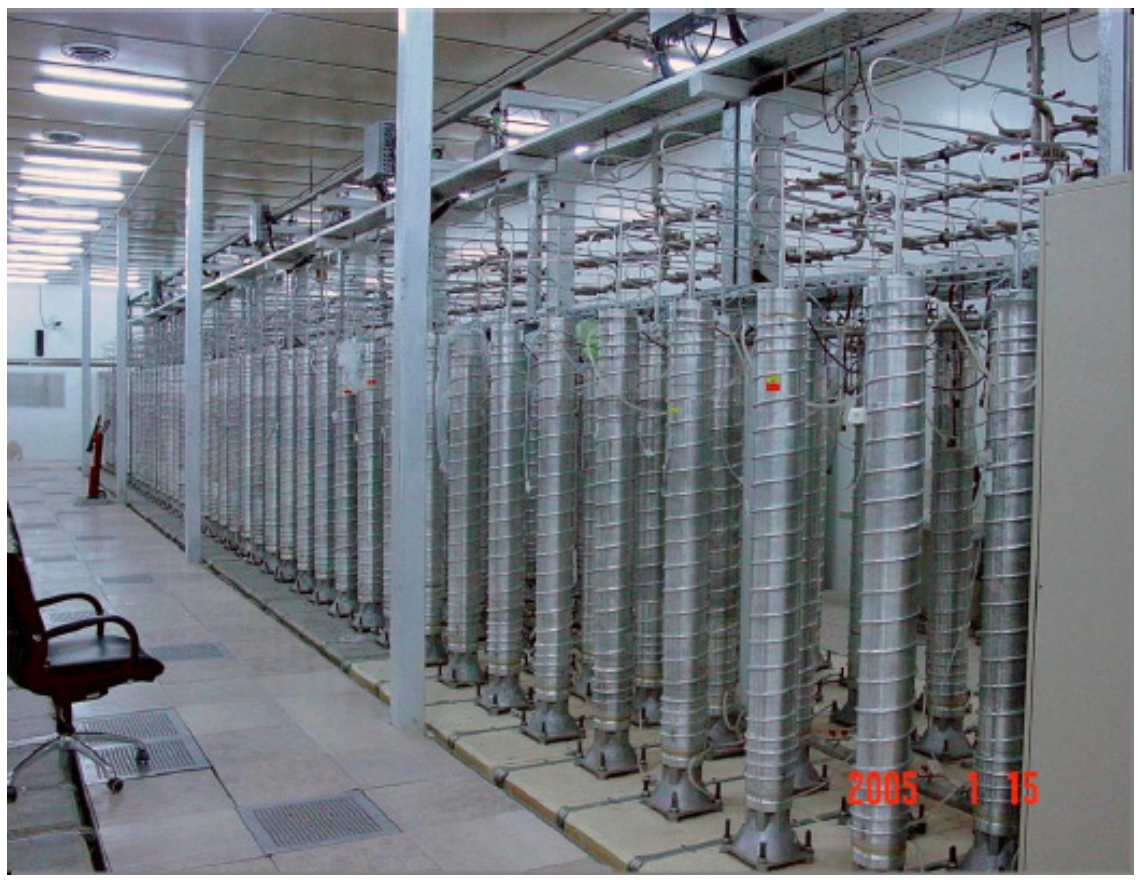

Fig. 33. The 164-centrifuge cascade at the Natanz PFEP, Iran. Source: Wood $^{133}$

As of the annual Physical Inventory Verification carried out at the FEP in November 2008, the IAEA reports that Iran had fed a total of $9956 \mathrm{~kg}$ of natural $\mathrm{UF}_{6}$ and produced a total of $839 \mathrm{~kg}$ of LEUF 6 , and ES by the IAEA verified the production of uranium enriched up to $4.2 \%{ }^{235} \mathrm{U}$. In the February 2009 Director General's report to the Board of Governors, the IAEA reported that Iran was enriching uranium in twenty-four 164-centrifuge cascades, vacuum testing nine more, and installing three more, for a total of 36 cascades - making up two full 18-cascade units of the plant. Furthermore, initial installation of pipes and cables was proceeding on three more units. ${ }^{134}$

Table 3 shows the progression of cascade operation at the Natanz FEP. The following figures reflect the data from the table: Fig. 34 shows a chart of centrifuge operation at the Natanz FEP, and Fig. 35 shows total $\mathrm{UF}_{6}$ feed and production; data for both charts were collected from the IAEA Director General's reports to the Board of Governors.* The IAEA is continuing to implement safeguards-including unannounced inspections and containment and surveillance measures-at the facilities at Natanz. ${ }^{135}$

According to a prepared statement by U.S. National Intelligence Director Dennis Blair to the U.S. Senate Armed Services Committee in March 2009, the U.S. intelligence community judges that Iran's continued uranium enrichment efforts indicate that Iran "at a minimum is keeping open the option to develop" nuclear weapons in the future, although Blair confirmed that the U.S. intelligence community still believes that Iran halted weaponization activities in 2003. Blair highlighted that production of fissile material is one of three legs of an effective nuclear weapons capability (the other two legs being delivery system development and weaponization/warhead development and testing). ${ }^{136}$ In his testimony before the committee, Blair acknowledged that intelligence agencies in other states, especially Israel, could interpret the intentions and capabilities of Iran differently based on the same available facts. ${ }^{137}$

\footnotetext{
* The production of these charts was prompted by a similar chart based on the same data at ArmsControlWonk.com
} (Jeffrey Lewis, “Nine cascades in vacuum,” 24 February 2009). 
Table 3. Progression of operations at Natanz FEP

\begin{tabular}{|c|c|c|c|c|c|c|c|}
\hline \multirow[b]{2}{*}{ IAEA report date } & \multirow{2}{*}{$\begin{array}{c}\text { IAEA report } \\
\text { number }\end{array}$} & \multicolumn{3}{|c|}{ No. of Cascades (No. of Centrifuges) } & \multirow[b]{2}{*}{$\begin{array}{c}\text { Total feed } \\
\text { (kg UF }_{6} \text { ) }\end{array}$} & \multirow{2}{*}{$\begin{array}{c}\text { Total LEU } \\
\text { product } \\
\text { (kg UF }_{6} \text { ) }\end{array}$} & \multirow[b]{2}{*}{$\begin{array}{l}\text { Enrichment } \\
\left(\text { wt } \% ~^{235} U\right)^{\mathrm{a}}\end{array}$} \\
\hline & & $\begin{array}{l}\text { Operating } \\
\text { with } \mathbf{U F}_{6}\end{array}$ & Installed & $\begin{array}{c}\text { Under } \\
\text { construction }\end{array}$ & & & \\
\hline 22 February 2007 & GOV/2007/8 & 0 & $2(328)$ & $2(328)$ & 0 & 0 & - \\
\hline 23 May 2007 & GOV/2007/22 & 8 (1312) & $2(328)$ & $3(492)$ & 260 & - & - \\
\hline 30 August 2007 & GOV/2007/48 & $12(1968)$ & $2(328)$ & $2(328)$ & 690 & - & 3.7 \\
\hline 15 November 2007 & GOV/2007/58 & $18(2952)$ & 0 & 0 & 1,240 & - & 4 \\
\hline 22 February 2008 & GOV/2008/4 & $18(2952)$ & 0 & 0 & 1,670 & 75 & - \\
\hline 26 May 2008 & GOV/2008/15 & $20(3280)$ & $1(164)$ & $15(2460)$ & 3,970 & - & 4 \\
\hline 15 September 2008 & GOV/2008/38 & $23(3772)$ & $1(164)$ & 12 (1968) & 7,600 & 480 & 4 \\
\hline 19 November 2008 & GOV/2008/59 & $23(3772)$ & $1(164)$ & 12 (1968) & $9,750^{\mathrm{b}}$ & $630^{b}$ & 4 \\
\hline 19 February 2009 & GOV/2009/8 & $24(3936)$ & $9(1476)$ & $3(492)$ & $12,000^{\mathrm{C}}$ & 1010 & 4.2 \\
\hline
\end{tabular}

${ }^{a}$ Maximum enrichment based on IAEA environmental sampling (samples taken previously but results reported on the given date).

${ }^{\mathrm{b}}$ Annual Physical Inventory Verification on 17 November 2008 verified 9956 kg UF 6 feed and 839 kg UF 6 product.

${ }^{\mathrm{c}}$ Approximate value based on declared product and previous feed/product ratio.

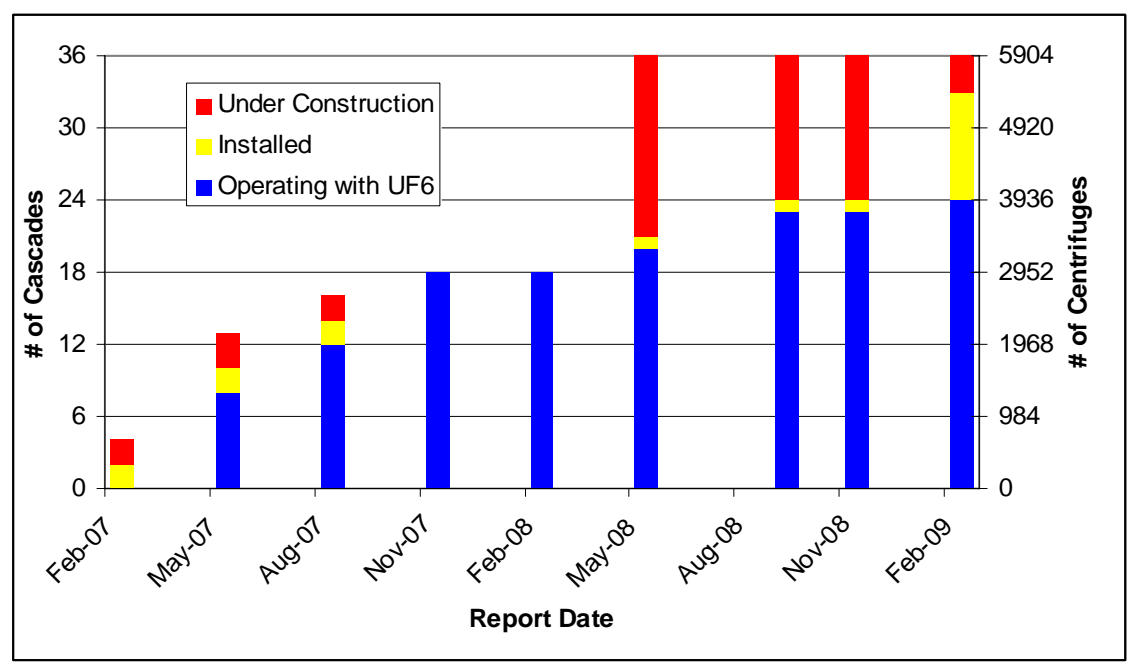

Fig. 34. Centrifuge installation and operation at Natanz FEP, Iran.

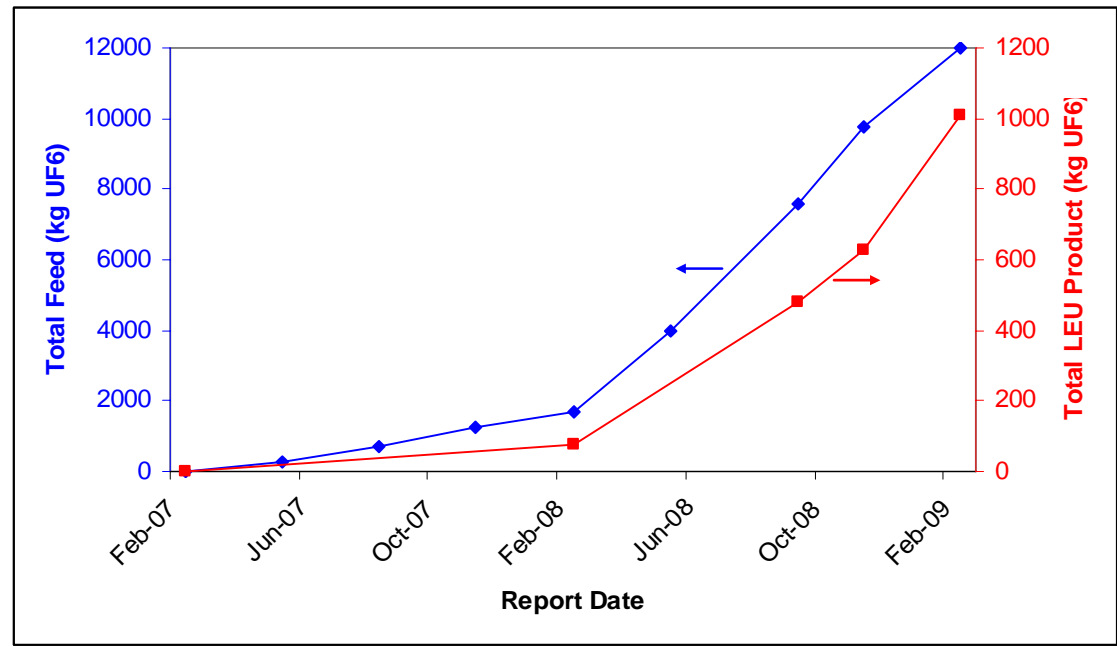

Fig. 35. $\mathrm{UF}_{6}$ feed and production at Natanz FEP, Iran. 


\section{NON-NPT STATES}

Two states that are not parties of the Non-Proliferation Treaty (NPT), India and Pakistan, are known to have developed enrichment capabilities. Both have tested nuclear devices, although only Pakistan is believed to utilize uranium enrichment as a key component of its nuclear weapons program.

There have been reports that the Democratic People’s Republic of Korea (DPRK, "North Korea”) has been developing a clandestine enrichment capability as part of a nuclear weapons program. An unclassified 2002 U.S. National Intelligence Estimate said that DPRK had done at least research and development for an HEU project, and subsequent unclassified intelligence reports to the U.S. Congress stated that DPRK was constructing a full-scale enrichment facility. ${ }^{138}$

In an interview with National Public Radio in March 2007, Christopher Hill, then-Assistant Secretary of State for East Asian and Pacific Affairs and head of the U.S. delegation to the Six Party Talks, stated that the United States continues "to assess that North Korea has attempted and succeeded in buying a number of parts to put together a uranium enrichment program. How far they got and whether they were successful in actually manufacturing highly enriched uranium, that’s hard to say."139,140

There continues to be a high level of uncertainty about the nature and extent of DPRK's uranium enrichment program, prompting questions and debate from nongovernmental analysts and members of Congress. For example, Selig Harrison of the Center for International Policy wrote in Foreign Affairs in 2005 that the "administration presented a worst-case scenario as an incontrovertible truth and distorted its intelligence on North Korea."141 Former administration officials Mitchell Reiss and Robert Gallucci responded in the next issue of Foreign Affairs that "the case has been made and is credible."142 A February 2007 analysis from ISIS concluded that DPRK likely obtained centrifuge equipment from the A. Q. Khan network but stated that it is not clear that an enrichment facility was ever built. ${ }^{143}$ In March 2007 U.S. Senator Carl Levin, Chairman of the Senate Armed Services Committee, wrote to the U.S. Secretaries of State and Defense asking for clarification of intelligence regarding DPRK's uranium enrichment program, after Congressional testimony by administration officials and media reports suggested that government officials were downplaying previous assessments. ${ }^{144}$ In testimony to the U.S. Senate Armed Services Committee in March 2009, U.S. National Intelligence Director Dennis Blair confirmed that the U.S. intelligence community "continues to assess that North Korea has pursued a uranium enrichment capability in the past," and added that "some in the intelligence community have increasing concerns that North Korea has an ongoing covert uranium enrichment program."145

Israel, the final non-NPT state, is also widely believed to have nuclear weapons, but these are largely thought to be plutonium weapons. A former Dimona technician, Mordechai Vanunu, leaked information and photographs of activities at Dimona to the British press in 1986, confirming that Israel had focused on constructing plutonium-based nuclear weapons. ${ }^{146}$ Israel may have laboratory-scale enrichment facilities at its Dimona nuclear complex. A 1974 CIA memorandum referred to the "ambiguous nature of Israeli efforts in the field of uranium enrichment."147

\subsection{INDIA}

India began a nuclear weapons program in the 1960s over security threats from China and Pakistan. India's weapons program focused on plutonium production using heavy water "research reactors" at the Bhabha Atomic Research Centre (BARC) in Trombay, especially the Canadian-designed CIRUS reactor that began operation in 1960 (Fig. 36). Uranium enrichment has not played a large role in India's civilian nuclear program either, since most of its power reactors are also heavy water reactors that use natural uranium fuel. India began operating a 100-centrifuge test cascade at BARC in 1985 and constructed a small GCEP called the Rattehalli Rare Materials Plant near Mysore in the late 1980s (Fig. 37). ${ }^{148}$ This plant is reportedly intended to produce HEU (with $30-45 \%{ }^{235} \mathrm{U}$ ) for a possible nuclear-powered 
submarine program. ${ }^{149}$ BARC is continuing to design and test more advanced centrifuges for use at Rattehalli; the director of BARC announced in October 2008 that "third-generation" machines were currently being installed at Rattehalli and that an experimental cascade of "fourth-generation" centrifuges is operating at BARC. ${ }^{150}$

India has agreed to submit the nuclear reactors and fuel cycle facilities that it designates as "civilian" to safeguards as part of the U.S.-India civilian nuclear cooperation agreement of 2005. ${ }^{151}$ However, no enrichment-related research and none of India's enrichment facilities will be subject to safeguards under the safeguards agreement that India signed in February 2009. ${ }^{152}$

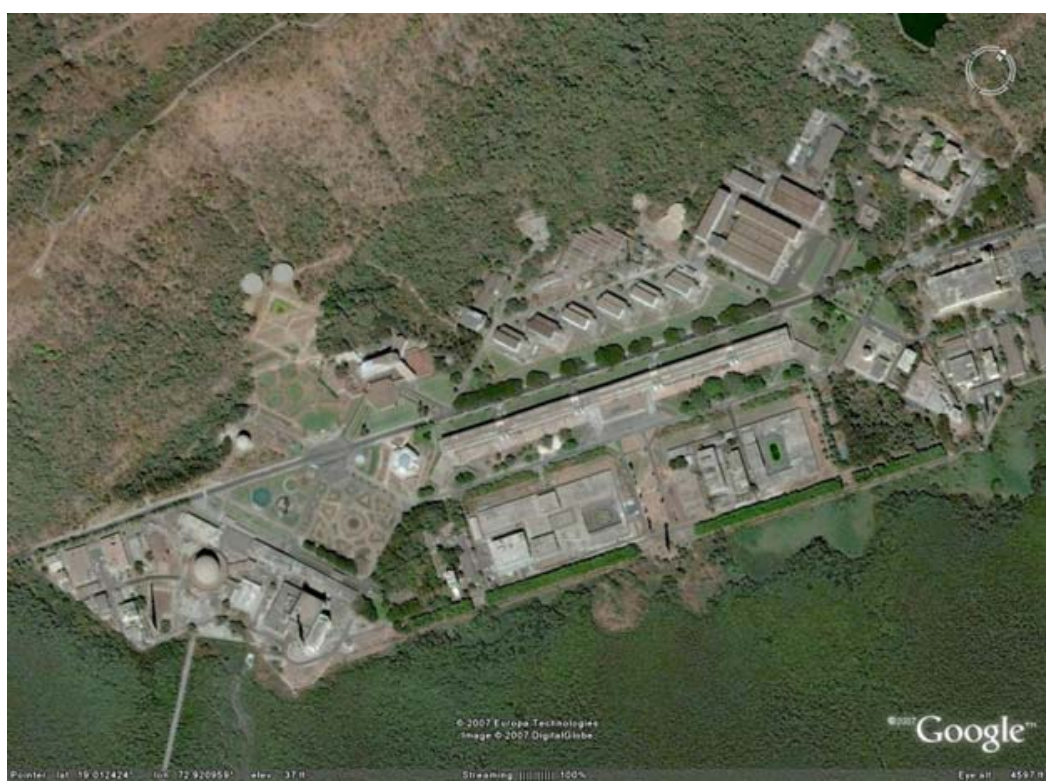

Fig. 36. Bhabha Atomic Research Centre, India. Source: Google Earth

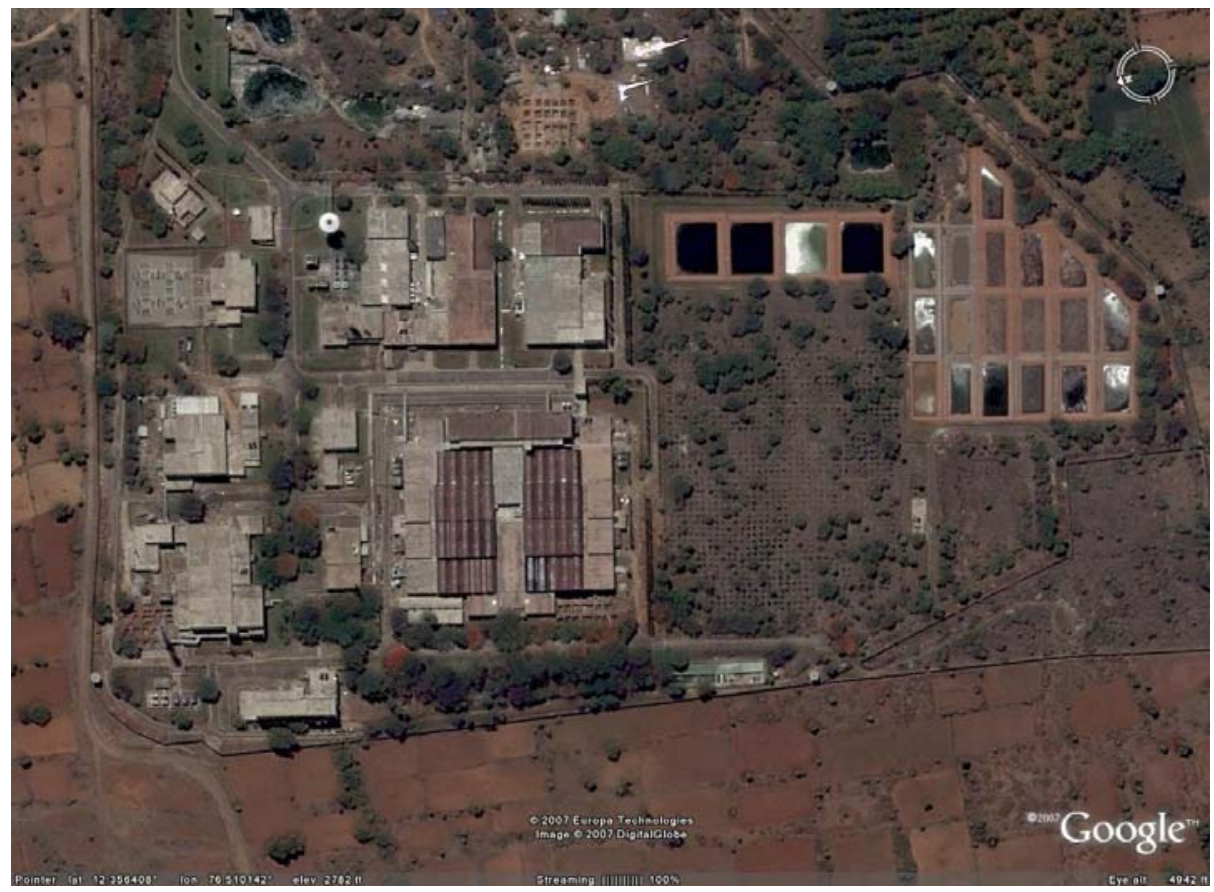

Fig. 37. Rattehalli Rare Materials Plant, India. Source: Google Earth 


\subsection{PAKISTAN}

Pakistan began a nuclear weapons program in earnest in 1974 after India tested a nuclear device. While initially focusing on plutonium production through foreign-supplied reactors, the program shifted its attention to uranium enrichment after foreign suppliers pulled out and A. Q. Khan returned from the Netherlands in 1975. A. Q. Khan had worked for the Urenco subcontractor FDO (Fysisch Dynamisch Onderzoekslaboratorium) at Almelo, ${ }^{153}$ and when he came to Pakistan, he brought stolen centrifuge plans as well as contacts with centrifuge component suppliers, forming the basis of Pakistan's uranium enrichment program as well as the "Khan network," an international nuclear black market believed to have supplied centrifuge technology to Libya, Iran, and DPRK (see above sections on these states for further discussion). In Pakistan, Khan founded what became the Khan Research Laboratory (KRL) at Kahuta (Fig. 38), Pakistan's primary enrichment facility, overseen by the Pakistan Atomic Energy Commission (PAEC). The capacity of the GCEP at KRL is not well known; estimates range from 5,000 SWU/year up to over 100,000 SWU/year, ${ }^{154}$ while the general consensus is that the capacity is somewhere in the range of 15,000-20,000 SWU/year.

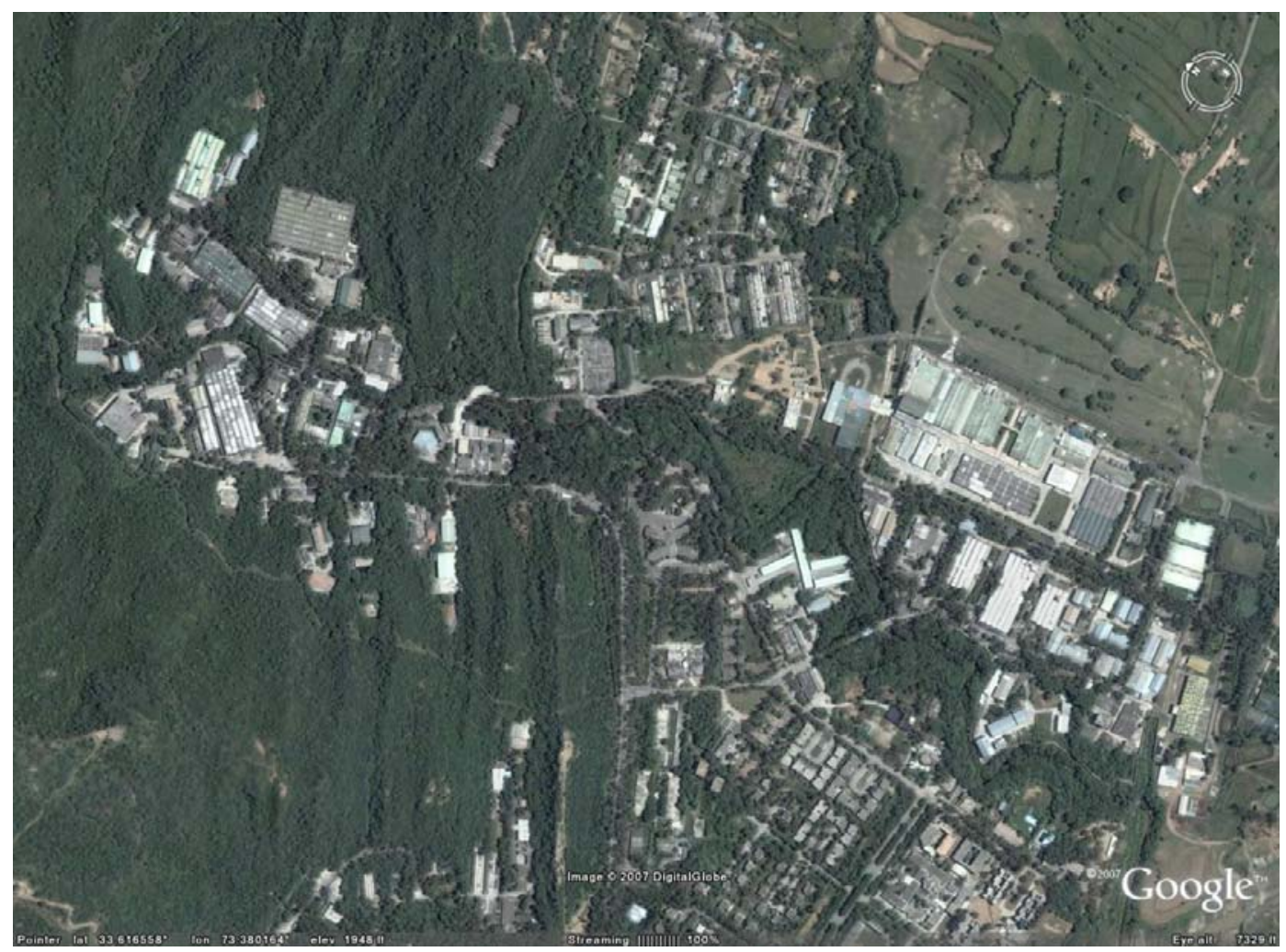

Fig. 38. Khan Research Laboratory, Kahuta, Pakistan. Source: Google Earth

There have been unconfirmed reports since the 1980s that Pakistan may be constructing another GCEP at Golra Sharif outside of Islamabad. A 2007 news report stated that the PAEC may build a large commercial enrichment plant as part of the planned Pakistan Nuclear Power Fuel Complex (PNPFC) in Kundian, near the Chashma power reactors. ${ }^{155,156}$ None of Pakistan’s enrichment facilities are currently subject to safeguards. However, the Kyodo report suggests that Pakistan may be willing to submit the new plant at Kundian to safeguards as part of a nuclear deal similar to the U.S.-Indian nuclear deal of 2005. 


\section{CONCLUSION}

Currently, the world enrichment capacity is approximately 56 million SWU/year, with 22.5 million SWU/year in GDPs and more than 33 million SWU/year in GCEPs. Most capacity is concentrated in Russia, the United States, France, and the three Urenco countries, with China and Japan rounding out the bulk of the capacity. The capacity to produce another 34 million SWU/year is under construction or planned for the near future, almost entirely using gas centrifuge separation. Laser isotope separation may become the technology of choice for new enrichment plants in the future, but current enrichment plants will probably continue operating as long as it is economical to do so.

Politicians and diplomats have discussed the idea of limiting the spread of enrichment technology to current technology holders, designating a fixed group of enrichment "supplier" countries in the same way that the list of official nuclear weapon states was established as those countries with nuclear weapons at the first signing of the NPT in 1968. ${ }^{157,158}$ Plans for small enrichment programs by states such as Iran, Brazil, Argentina, South Africa, and Australia may be partially based on the desire to be considered among these "supplier" countries if such a distinction ever becomes official. One possible alternative is the creation of international fuel centers, ${ }^{159}$ such as the proposed center at Angarsk in Russia, which would make enrichment services more widely available and ensure nuclear fuel supplies for member states.

The demand for new uranium enrichment capacity is expected to increase significantly over the next several decades (Fig. 39). More fuel will be required for the nuclear reactors being planned and built, and the current supply of enrichment services will start to decrease as the older GDPs are shut down and alternative sources of fuel, such as through HEU blend-down, are depleted (the U.S.Russian Megatons-to-Megawatts program is expected to end in $2013^{160}$ ). As demand starts to exceed supply, the economics for investing in new enrichment plants will begin to look more attractive.

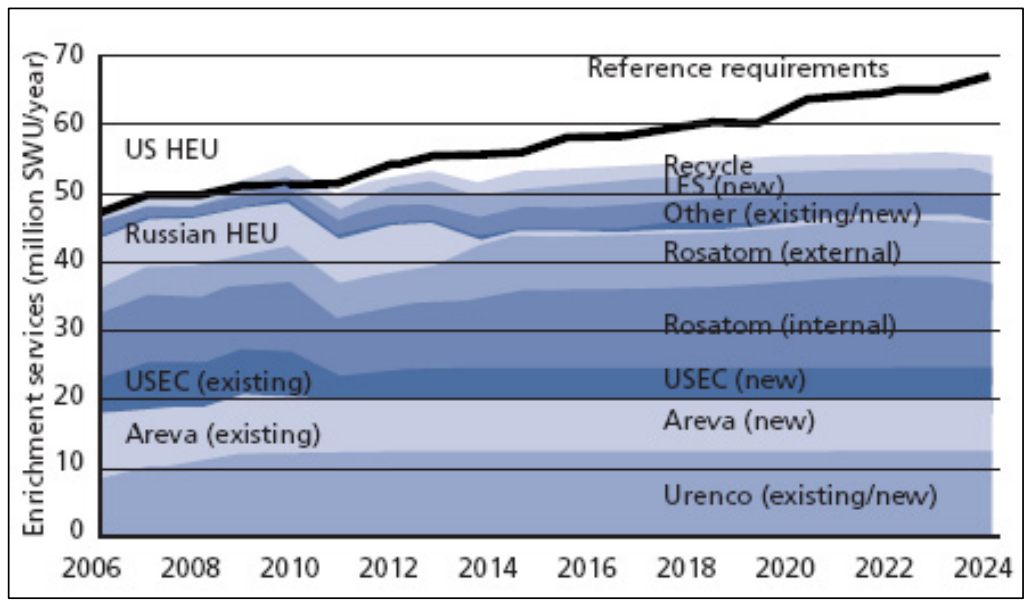

Fig. 39. Projected world enrichment capacity and demand. Source: Touch Briefings ${ }^{161}$

The techniques and implementation of safeguards continue to evolve as the IAEA investigates new measures and incorporates new technologies. ${ }^{162}$ The IAEA member states have worked to expand the scope of the agency's authority by implementing strengthened safeguards and encouraging states to adopt an Additional Protocol. ${ }^{163}$ Advanced safeguards technologies such as more effective enrichment monitors, unattended monitoring, and uranium cylinder tracking can assist in better meeting the HSP goals of detecting diversion of declared material at declared facilities; additional measures such as ES and widearea monitoring provide some capability to detect undeclared materials and facilities. ${ }^{164,165,166}$ The IAEA has begun implementing an updated model safeguards approach for GCEPs along with advanced technology — an effort that began with the HSP in the early 1980s and may continue in the future with an "HSP+" collaboration between operators and technology holders- to continue to efficiently and effectively apply safeguards as more uranium enrichment facilities come online in more countries. ${ }^{167}$ 


\section{REFERENCES}

${ }^{1}$ M. D. Laughter, “Profile of World Uranium Enrichment Programs—-2007,” ORNL/TM-2007/193, November 2007.

2 “EURODIF Production,” Areva NC website, 2006, www.areva-nc.com.

3 “U.S.-Russian Megatons to Megawatts Program: About the Program,” USEC, June 2007, www.usec.com.

${ }^{4}$ D. W. Swindle, "Realities of verifying the absence of highly enriched uranium (HEU) in gas centrifuge enrichment plants,” Meeting of the American Physical Society, March 1990, Anaheim, California, K/ITP-327.

5 “Treaty on the Non-Proliferation of Nuclear Weapons,” IAEA, INFCIRC/140, 22 April 1970, www.iaea.org.

6 "Agreement between the United States of America and the Agency for the Application of Safeguards in the United States of America,” the 'Voluntary Offer Agreement,' IAEA, INFCIRC/288, December 1981, www.iaea.org.

${ }^{7}$ Geoff Hiscock, “Australia, China sign uranium deal,” CNN, 2 April 2006, www.cnn.com.

${ }^{8}$ IAEA Nuclear Fuel Cycle Information System (NFCIS), 2007, www-nfcis.iaea.org.

${ }^{9}$ USEC Inc., “USEC Facilities,” www.usec.com.

${ }^{10}$ D. A. Waters, “The American Gas Centrifuge: Past, Present, and Future,” USEC, Separation Phenomena in Liquids and Gases Workshop, 13 October 2003.

${ }^{11}$ USEC Inc., “USEC Inc. suspends AVLIS technology development,” Press Release, 9 June 1999, www.usec.com.

${ }^{12}$ Dan Charles, “Spinning a nuclear comeback,” Science 315, pp. 1782-1784, 30 March 2007.

${ }^{13}$ USEC Inc., “USEC updates progress on Lead Cascade, American Centrifuge Project,” Press Release, 1 August 2007, www.usec.com.

${ }^{14}$ USEC Inc., “USEC updates American Centrifuge progress,” Press Release, 4 November 2008, www.usec.com.

${ }^{15}$ USEC Inc., “USEC provides update on American Centrifuge,” Press Release, 5 February 2009, www.usec.com.

16 “Louisiana Energy Services (LES) Gas Centrifuge Facility,” NRC New Fuel Facility Licensing, 31 August 2007, www.nrc.gov/materials/fuel-cycle-fac/lesfacility.html.

${ }^{17}$ Urenco, "Building the National Enrichment Facility,” www.urenco.com.

18 "NRC issues license to Louisiana Energy Services for gas centrifuge uranium enrichment plant in New Mexico," NRC Press Release, 23 June 2006, www.nrc.gov.

${ }^{19}$ Urenco, “National Enrichment Facility to expand,” Urenco Press Release, 21 November 2008, www.urenco.com.

${ }^{20}$ Daniel Horner, “LES plans to double capacity at New Mexico SWU plant,” Nuclear Fuel 33, No. 24, 1 December 2008.

${ }^{21}$ Urenco, "Uranium hexafluoride arrives at National Enrichment Facility,” Urenco Press Release, 25 February 2009, www.urenco.com. 
${ }^{22}$ Areva, "Expanding the U.S. nuclear infrastructure by building a new uranium enrichment facility," Preapplication meeting with the U.S. NRC, 21 May 2007, www.nrc.gov.

${ }^{23}$ Areva, “AREVA selects Bonneville County, Idaho, for its U.S. uranium enrichment facility,” Areva Press Release, 6 May 2008, www.areva.com.

${ }^{24}$ Areva, “AREVA selects name for new U.S. enrichment facility,” Areva Press Release, 31 July 2008, www.areva.com.

${ }^{25}$ Daniel Horner, “Contracts worth billions signed for Eagle Rock output, Areva says,” Nuclear Fuel 33, No. 25, 15 December 2008.

${ }^{26}$ Areva Inc., “AREVA provides update on Eagle Rock Enrichment Facility project,” Areva Press Release, 2 March 2009, www.us.areva-nc.com.

27 “Areva maps out Eagle Rock expansion,” World Nuclear News, 22 April 2009, www.world-nuclear-news.org.

28 “Russia ready to consider a U-enrichment plant construction in US,” Nuclear.Ru, 5 March 2008, www.nuclear.ru/eng.

${ }^{29}$ Ann MacLachlan and Daniel Horner, "Russia exploring building centrifuge plant in US,” Nuclear Fuel 33, No. 5, 10 March 2008.

${ }^{30}$ GE Energy, "GE signs agreement with Silex Systems of Australia to develop uranium enrichment technology," Press Release, 22 May 2006, www.ge-energy.com.

${ }^{31}$ GE Energy, “GE, Hitachi sign formation agreement for global nuclear energy business alliance,” Press Release, 16 May 2007, www.ge-energy.com.

${ }^{32}$ GE Energy, “Cameco joins GE and Hitachi in Global Laser Enrichment venture,” GE Energy Press Release, 20 June 2008, www.ge-energy.com.

${ }^{33}$ Silex Systems Ltd., “Project and Operation Update,” 26 February 2009, www.silex.com.au.

${ }^{34}$ Silex Systems Ltd., “About Silex,” “Company History,” and “Announcements,” www.silex.com.au.

${ }^{35}$ GE-Hitachi Nuclear Energy, "GE Hitachi Nuclear Energy selects Wilmington, NC, as site for potential commercial uranium enrichment facility,” GEH Press Release, 30 April 2008, www.ge-energy.com.

${ }^{36}$ Steven Dolley, “Exelon, Entergy express support for GE-Hitachi laser enrichment,” Nuclear Fuel 32, No. 21, 8 October 2007.

${ }^{37}$ IAEA NFCIS, 2007.

38 “Our Sites: Capenhurst,” UK Nuclear Decommissioning Authority, www.nda.gov.uk.

${ }^{39}$ Urenco, “URENCO UK Ltd (Capenhurst),” www.urenco.com.

${ }^{40}$ Urenco, “AboutU: URENCO News Magazine,” Winter 2008, www.urenco.com.

41 “Summary report: centrifuge enrichment plant safeguards at Urenco plants,” U.S. DOE and Urenco officials, 1 October 2004. 
${ }^{42}$ Oleg Bukharin, "Russia’s gaseous centrifuge technology and uranium enrichment complex," Program on Science and Global Security, Woodrow Wilson School of Public and International Affairs, Princeton University, January 2004.

${ }^{43}$ Ann MacLachlan, “Russian SWU center wooing EU countries,” Nuclear Fuel 33, No. 24, 1 December 2008.

${ }^{44}$ Kazatomprom Press Release, 22 July 2008, www.kazatomprom.kz.

${ }^{45}$ Ann MacLachlan, “KAP explores stake in GB II but says Angarsk sufficient for now,” Nuclear Fuel 33, No. 15, 28 July 2008.

${ }^{46}$ Peter Diehl, “Re-enrichment of West European depleted uranium tails in Russia,” Ecodefense Russia, 2004.

${ }^{47}$ Mark Hibbs et al., “Russia to stop commercial tails re-enrichment,” Nuclear Fuel, 31, No. 16, 31 July 2006.

48 "First uranium enrichment center to open in Siberia - Kiriyenko,” RIA Novosti, 15 July 2006, http://en.rian.ru/russia/20060715/51394941.html.

${ }^{49}$ D.Albright, F. Berkhout, and W. Walker, "Inventories of highly enriched uranium in the nuclear weapon states," in Plutonium and Highly Enriched Uranium 1996: World Inventories, Capabilities and Policies, SIPRI, 1996, www.sipri.org.

50 "Disarmament champion,” News from France, French Embassy Press and Information Service, 96-4, 1 March 1996, www.info-france-usa.org.

${ }^{51}$ Ann MacLachlan, “HEU production ends at Pierrelatte,” Nuclear Fuel 21, No. 15, 15 July 1996.

${ }^{52}$ IAEA NFCIS, 2007.

${ }^{53}$ Areva, "Uranium products and services: Enrichment,” www.us.areva-nc.com.

${ }^{54}$ Ron Witzel, “Enrichment Supply Assessment,” Longenecker and Associates, May 2007.

${ }^{55}$ Areva, "AREVA and URENCO announce the creation of the Joint Venture ETC," and "The way is open for the construction of the new Georges Besse II enrichment plant,” Press Releases, 3 July 2006, www.areva.com.

${ }^{56}$ Ann MacLachlan, “Areva says GB II plant on time, denies schedule challenges,” Nuclear Fuel 33, No. 5, 10 March 2008.

${ }^{57}$ Areva, "Enrichment: AREVA completes a major stage in the Georges Besse II project,” Areva Press Release, 19 February 2008, www.areva.com.

${ }^{58}$ Areva, Pre-application meeting with the U.S. NRC, 21 May 2007.

${ }^{59}$ Areva, "SUEZ acquires an equity stake in AREVA's new uranium enrichment plant," Areva Press Release, 3 June 2008, www.areva.com.

${ }^{60}$ Areva, “Georges Besse II: A new era for enrichment,” Areva brochure, May 2007, www.areva.com.

${ }^{61}$ Ann MacLachlan, “ESA concerned about EU’s supply of enriched U,” Nuclear Fuel 33, No. 9, 5 May 2008.

${ }^{62}$ SIPRI, 1996. 
${ }^{63}$ James Bodgener, “China’s military legacy,” Nuclear Engineering International 53, No. 48, p. 23, July 2008.

${ }^{64}$ IAEA NFCIS, 2007.

${ }^{65}$ Bowen et al., "Nuclear- and missile-related trade and developments for selected countries, March-June 1999: China," The Nonproliferation Review, Fall 1999, pp. 179-199.

${ }^{66}$ Alexei Breus, "Sino-Russian agreement signed for fourth centrifuge plant stage," Nuclear Fuel 33, No. 11, 2 June 2008.

${ }^{67}$ Bukharin, 2004.

${ }^{68}$ A. Panasyuk et al., "Tripartite enrichment project: safeguards at enrichment plants equipped with Russian centrifuges,” IAEA Symposium on International Safeguards, Vienna, 2001, IAEA-SM-367/8/02. wwwpub.iaea.org.

${ }^{69}$ Urenco, “Extending Our Global Reach: Annual Report and Accounts 2006,” www.urenco.com.

${ }^{70}$ Urenco, “Building for the Future: Annual Report and Accounts 2007,” www.urenco.com.

${ }^{71}$ Urenco, “AboutU: URENCO News Magazine,” Winter 2008, www.urenco.com.

${ }^{72}$ Urenco, “URENCO Deutschland (Gronau),” www.urenco.com.

${ }^{73}$ B.G. Dekker and E.F.M. Steinebach, "The development and experience of safeguards at the Dutch and German uranium enrichment plants (Urenco),” Transactions of the American Nuclear Society, $3^{\text {rd }}$ International Conference on Facility Operations-Safeguards Interface, San Diego, 1987, Vol. 55, Supl. 1, p. 12.

${ }^{74}$ Urenco, “URENCO Nederland (Almelo),” www.urenco.com

${ }^{75}$ J. K. Aaldijk et al., "Gamma techniques for IAEA safeguards at centrifuge enrichment cascades,” Transactions of the American Nuclear Society, $3^{\text {rd }}$ International Conference on Facility Operations-Safeguards Interface, San Diego, 1987. Vol. 55, Supl. 1, p. 13.

${ }^{76}$ S. Yonekawa et al., "Current status and future plan of uranium enrichment technology,” Transactions of the American Nuclear Society, 1994 Winter Meeting, Washington D.C., Vol. 71, p. 77.

${ }^{77}$ Masato Hori, “Centrifuge dismantling at Uranium Enrichment Facility,” JNC, IAEA Technical Meeting on Techniques for the Verification of Enrichment Activities, Vienna, April 2005.

${ }^{78}$ IAEA NFCIS, 2007.

${ }^{79}$ Mark Hibbs, “Japan revised, slimmed down its carbon fiber centrifuge,” Nuclear Fuel 32, No. 11, 21 May 2007.

${ }^{80}$ JNFL, “Our Business: Uranium Enrichment,” www.jnfl.co.jp/english/uranium.html.

${ }^{81}$ JNFL, "Start of the cascade test at the Uranium Enrichment Plant,” Press Release, 2 April 2007, www.jnfl.co.jp.

${ }^{82}$ JNFL, “Start of the centrifuge cascade test using uranium hexafluoride,” Press Release, 12 November 2007, www.jnfl.co.jp.

${ }^{83}$ Ruthanne Neely, Cheryl Moss Herman, and Jonathan Hinze, “A busy year for SWU,”Nuclear Engineering International, 1 September 2008, www.neimagazine.com. 
${ }^{84}$ Simon Shuster, “Russia nuclear reach extends to Asia on Toshiba deal,” Reuters, 19 March 2009.

${ }^{85}$ M. Hayashi et al., "Present status of safeguards implementation in Japan,” IAEA Symposium on International Safeguards, Vienna, 1994, IAEA-SM-333/39. www-pub.iaea.org.

${ }^{86}$ Australian Nuclear Science and Technology Organisation, "Clarification on ABC 7.30 Report's uranium enrichment story,” Media Statement, 15 June 2007, www.ansto.gov.au.

${ }^{87}$ Jodie Evans and Russell Leslie, “Australia’s gas centrifuge program and safeguards related research,” ASNO, presentation to the IAEA Technical Working Group on Enrichment, Vienna, 18-22 May 2005.

${ }^{88}$ John Carlson, "The prospects for uranium enrichment in Australia—correcting the record,” Media Release, Australian Department of Foreign Affairs and Trade, 18 June 2007, www.dfat.gov.au.

89 “Project and Operational Update,” Silex Systems Limited, 30 August 2007, www.silex.com.au.

${ }^{90}$ ABACC, www.abacc.org.

${ }^{91}$ O. M. Guidicini et al., "Development of low-level environmental sampling capabilities for uranium at Brazilian and Argentine laboratories by ABACC," ABACC, 2003, www.abacc.org.

${ }^{92}$ O. M. Guidicini et al., "The development of low-level measurement capabilities for total and isotopic uranium in environmental samples at Brazilian and Argentine laboratories by ABACC,” Journal of Nuclear Materials Management 33, No. 4, pp. 4-12, Summer 2005.

${ }^{93}$ H. E. Vicens, M. A. Marzo, and V. E. Nunes, “Considerations on safeguards approach for small centrifuge enrichment facilities,” ABACC, 2004, www.abacc.org.

94 “Argentina, Brazil to build joint uranium enrichment plant,” AFP, 22 February 2009.

${ }^{95}$ Mark Hibbs, “Argentina, Brazil negotiating future enrichment joint venture,” Nuclear Fuel 33, No. 20, 6 October 2008.

${ }^{96}$ Mohamed El Baradei, "Introductory Statement to the Board of Governors," Statement by the IAEA Director General to the Board of Governors, 13 September 2004, www.iaea.org.

${ }^{97}$ Mark Hibbs, “77\% U-235 was peak enrichment reported to IAEA by South Korea,” Nuclear Fuel 29, No. 20, p. 7, 27 September 2004.

${ }^{98}$ IAEA NFCIS.

${ }^{99}$ Sharon Squassoni and David Fite, "Brazil as litmus test: Resende and restrictions on uranium enrichment," Arms Control Today, October 2005.

${ }^{100}$ Steve Kingstone, “Brazil joins world’s nuclear club,” BBC News, 6 May 2006.

${ }^{101}$ INB, “CNEN grants permission to the uranium enrichment plant in the INB," INB Press Release (in Portuguese), 8 January 2009, www.inb.gov.br.

102 "Brazil to start enrichment uranium at Resende,” World Nuclear News, 14 January 2009, www.world-nuclearnews.org.

${ }^{103}$ R. Neely, C. M. Herman, and J. Hinze, “A busy year for SWU,” Nuclear Engineering International, 1 September 
2008, www.neimagazine.com.

${ }^{104}$ Mark Hibbs, “Bearing design prompted Brazil to withhold centrifuge data from IAEA,” Nuclear Fuel 29, No. 25, p. 1, 6 December 2004.

${ }^{105}$ Squassoni and Fite, 2005.

106 "In message to the Navy, Lula defends Brazilian nuclear program,” Statements by the Brazilian President, 11 June 2007, www.presidencia.gov.br/ultimas noticias.

${ }^{107}$ Mark Hibbs, “Brazil could expand Resende plant to 1 million SWU/year by 2030,” Nuclear Fuel 33, No. 22, 3 November 2008.

${ }^{108}$ Mark Hibbs, “NSG states engaging Brazil on Additional Protocol, ENR,” Nuclear Fuel 33, No. 22, 3 November 2008.

109 J. M. Whitaker. "Efforts to develop, test, and evaluate new techniques for strengthening international safeguards," 46 ${ }^{\text {th }}$ INMM Annual Meeting, Phoenix, Ariz., 14 July 2005.

110 "MinPlan in the News,” Statements by the Argentinean Minister of Planning, 23 August 2006, www.minplan.gov.ar.

${ }^{111}$ Mark Hibbs, “Argentina, Brazil negotiating future enrichment joint venture,” Nuclear Fuel 33, No. 20, 6 October 2008.

${ }^{112}$ AECL, “AECL signs agreement with Argentina to enter into negotiations for new CANDU unit," Press Release, 27 July 2007, www.aecl.ca.

113 “South Africa’s Nuclear Weapons Program: Putting Down the Sword,” Nuclear Weapon Archive, 2001, www.nuclearweaponarchive.org.

114 “South Africa’s Nuclear Weapons Program: An Annotated Chronology,” Monterey Institute of International Studies Center for Nonproliferation Studies, cns.miis.edu.

${ }^{115}$ Adolf von Baeckmann et al., "Nuclear verification in South Africa,” IAEA Bulletin, 37-1, f40.iaea.org/worldatom/Periodicals/Bulletin/.

${ }^{116}$ South African Department of Minerals and Energy, "Keynote address delivered by the Minister of Minerals and Energy at the launch of the SA Young Nuclear Professional Society,” 25 August 2006, www.dme.gov.za.

${ }^{117}$ South African Department of Minerals and Energy, "Nuclear Energy Policy and Strategy for the Republic of South Africa: Draft for Public Comment,” July 2007, www.dme.gov.za.

118 “Company Overview,” Klydon (Pty) Ltd., www.klydon.co.za.

119 “New South African enrichment process,” World Nuclear News, 4 September 2008, www.world-nuclearnews.org.

${ }^{120}$ David Albright, "Iraq’s programs to make highly enriched uranium and plutonium for nuclear weapons prior to the Gulf War,” Institute for Science and International Security, October 2002, www.isis-online.org.

${ }^{121}$ Albright, 2002. 
122 Jacques Baute, “Timeline Iraq,” IAEA Bulletin 46-1, pp. 64-68, June 2004.

123 “Iraq Nuclear Chronology,” Nuclear Threat Initiative Country Profiles, www.nti.org.

124 “In Focus: IAEA and Libya,” IAEA News Centre, www.iaea.org/NewsCentre.

${ }^{125}$ George W. Bush, "President announces new measures to counter the threat of WMD," Remarks by the President of the United States, Washington D.C., 11 February 2004, www.whitehouse.gov.

${ }^{126}$ IAEA, “Implementation of the NPT Safeguards Agreement of the Socialist People’s Libyan Arab Jamahiriya," Reports by the Director General, GOV/2004/12, 20 February 2004; GOV/2004/59, 30 August 2004.

${ }^{127}$ Frank Munger and Richard Powelson, “Secret shipment at Y-12,” Knoxville News Sentinel, 28 January 2004.

128 ““'Out of Sight’ Missions,” Oak Ridge National Laboratory Review, 39, No. 1, 2006.

129 “Iran Nuclear Chronology,” Nuclear Threat Initiative Country Profiles, www.nti.org.

${ }^{130}$ David Albright and Corey Hinderstein, “The Iranian gas centrifuge uranium enrichment plant at Natanz,” Institute for Science and International Security, 14 March 2003, www.isis-online.org/publications/iran/.

131 "Implementation of the NPT Safeguards Agreement in the Islamic Republic of Iran,” IAEA Director General's report to the Board of Governors, GOV/2007/48, 30 August 2007.

${ }^{132}$ David Albright and Jacqueline Shire, “IAEA safeguards report on Iran: limited progress on enrichment,” Institute for Science and International Security Issue Brief, 30 August 2007, www.isis-online.org/publications/iran/.

${ }^{133}$ Houston Wood, “Analysis of the proposed gas centrifuge plant at Natanz," $48^{\text {th }}$ Annual Meeting of the INMM, Tucson, Ariz., July 2007.

134 "Implementation of the NPT Safeguards Agreement ... in the Islamic Republic of Iran,” IAEA Director General's report to the Board of Governors, GOV/2009/8, 19 February 2009.

135 “Implementation of the NPT Safeguards Agreement ... in the Islamic Republic of Iran,” IAEA Director General's report to the Board of Governors, GOV/2008/59, 19 November 2008.

${ }^{136}$ Dennis Blair, “Intelligence community annual threat assessment,” Prepared Statement for the Senate Armed Services Committee by the National Intelligence Director, 10 March 2009, www.senate.gov.

137 "Hearing to receive testimony on the current and future worldwide threats to the national security of the United States,” U.S. Senate Committee on Armed Services, 10 March 2009, www.senate.gov.

${ }^{138}$ Paul Kerr, “N. Korea’s uranium-enrichment efforts shrouded in mystery,” Arms Control Today, May 2003, www.armscontrol.org.

139 “U.S., North Korea conclude talks on ties,” Morning Edition, National Public Radio, 7 March 2007, www.npr.org.

${ }^{140}$ Paul Kerr, "Doubts rise on North Korea’s uranium-enrichment program,” Arms Control Today, April 2007, www.armscontrol.org.

${ }^{141}$ S. S. Harrison, “Did North Korea cheat?” Foreign Affairs, January/February 2005, www.foreignaffairs.org. 
${ }^{142}$ M. B. Reiss and R. Gallucci, “Dead to Rights,” Foreign Affairs, March/April 2005, www.foreignaffairs.org.

${ }^{143}$ David Albright, "North Korea’s alleged large-scale enrichment plant: Yet another questionable extrapolation based on aluminum tubes,” Institute for Science and International Security, 23 February 2007, www.isisonline.org.

${ }^{144}$ Carl Levin, "Levin writes to Rice, Gates on North Korea,” Senator Carl Levin—Press Office, 2 March 2007 www.senate.gov/ levin.

${ }^{145}$ Dennis Blair, “Intelligence community annual threat assessment,” Prepared Statement for the Senate Armed Services Committee by the National Intelligence Director, 10 March 2009, www.senate.gov.

146 “Inside Dimona, Israel’s nuclear bomb factory,” "Revealed—The secrets of Israel's nuclear arsenal," and "How the experts were convinced,” The Sunday Times, London, 5 October 1986.

${ }^{147}$ David K. Shipler, “A-Arms capacity of Israelis: A topic rich in speculation,” New York Times, 29 October 1986.

${ }^{148}$ Mark Hibbs, “India to equip centrifuge plant with improved rotor assemblies,” Nuclear Fuel 22, No. 24, p. 7, 1 December 1997.

149 “India Nuclear Facilities,” Nuclear Threat Initiative Country Profiles, www.nti.org.

150 “BARC develops fourth gen uranium enrichment gas centrifuges,” Press Trust of India, 31 October 2008.

151 "Implementation of the India-United States Joint Statement of July 18, 2005: India’s Separation Plan,” Communication from the Permanent Mission of India to the IAEA, INFCIRC/731, 25 July 2008, www.iaea.org.

152 “India Safeguards Agreement signed,” IAEA Staff Report, 2 February 2009, www.iaea.org.

153 “Urenco centrifuge technology and proliferation,” Urenco, National Enrichment Facility Information Sheet, 9 March 2004, www.nefnm.com.

${ }^{154}$ Andreas Persbo, “Entering Khan’s little den,” Verification, 28 March 2007, verificationthoughts.blogspot.com.

155 “Pakistan to set up $2^{\text {nd }}$ uranium enrichment plant,” Kyodo News, 22 August 2007, www.kyodo.co.jp.

${ }^{156}$ Ihtasham ul Haque, “Plan for enhanced use of N-energy,” DAWN Internet Ed., 8 August 2007. www.dawn.com.

${ }^{157}$ George W. Bush, "President announces new measures to counter the threat of WMD,” Remarks by the President of the United States, Washington D.C., 11 February 2004, www.whitehouse.gov.

${ }^{158}$ James B. Steinberg, U.S. Deputy Secretary of State, speech to the Carnegie International Nonproliferation Conference, Washington, DC, 6 April 2009, www.carnegieendowment.org.

159 "Multilateral approaches to the nuclear fuel cycle: expert group report submitted to the Director General of the International Atomic Energy Agency,” IAEA, INFCIRC/640, 22 February 2005, www.iaea.org.

160 “U.S.-Russian Megatons to Megawatts Program: About the Program,” USEC, June 2007. www.usec.com.

${ }^{161}$ T. B. Meade and M. H. Schwartz. “The market for uranium enrichment services,” Touch Briefings' Nuclear Energy Review 2007, pp. 23-24, June 2007. www.touchbriefings.com. 
162 "Nuclear Nonproliferation: IAEA has strengthened its safeguards and nuclear security programs, but weaknesses need to be addressed,” U.S. Government Accountability Office, GAO-06-93, October 2005.

163 "Strengthening the effectiveness and improving the efficiency of the safeguards system including implementation of Additional Protocols," IAEA Director General's Report to the $51^{\text {st }}$ General Conference, GC(51)/8, 23 July 2007. www.iaea.org.

164 "Final Report of the Technical Meeting on Techniques for the Verification of Enrichment Activities,” Vienna, April 2005.

165 J. M. Whitaker et al. "Verification options for gas centrifuge enrichment plants,” ORNL/TM-2005/63, September 2005.

${ }^{166} \mathrm{~N}$. Khlebnikov et al. "Novel technologies for the detection of undeclared nuclear activities,” IAEA-CN-148/32, February 2007.

${ }^{167}$ Jill N. Cooley, "Model safeguards approach and innovative techniques implemented by the IAEA at gas centrifuge enrichment plants," IAEA Department of Safeguards, EPR-118, $48^{\text {th }}$ Annual Meeting of the INMM, Tucson, Ariz., July 2007. 